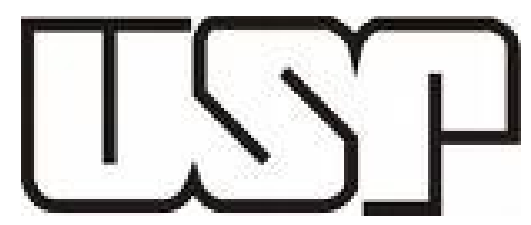

Universidade de São Paulo

Faculdade de Filosofia, Ciências e Letras de Ribeirão Preto

Departamento de Psicologia e Educação

\title{
Cotas Universitárias: perspectivas de estudantes em situação de vestibular
}

Fernanda Vieira Guarnieri 


\title{
RIBEIRÃO PRETO - SP \\ 2008
}

Universidade de São Paulo

Faculdade de Filosofia, Ciências e Letras de Ribeirão Preto

Departamento De Psicologia E Educação

\section{Cotas universitárias: perspectivas de estudantes em situação de vestibular}

\author{
Fernanda Vieira Guarnieri \\ Orientadora: Prof ${ }^{\mathrm{D}} \mathrm{Pr}^{\mathrm{a}}$ Lucy Leal Melo-Silva
}


Dissertação apresentada ao Programa de PósGraduação em Psicologia do Departamento de Psicologia e Educação da Faculdade de Filosofia, Ciências e Letras de Ribeirão Preto, Universidade de São Paulo, para a obtenção do título de mestre.

\section{RIBEIRÃO PRETO - SP}

2008 
DESDE QUE CITADA A FONTE, AUTORIZO A REPRODUÇÃO E DIVULGAÇÃO TOTAL OU PARCIAL DESTE TRABALHO POR MEIO IMPRESSO OU ELETRÔNICO, PARA FINS DE ESTUDO E PESQUISA.

Guarnieri, Fernanda Vieira.

Cotas Universitárias: perspectivas de estudantes em situação de vestibular / Fernanda Vieira Guarnieri; Orientadora Lucy Leal Melo-Silva. Ribeirão Preto - SP, 2008.

$131 \mathrm{p}$.

Dissertação (mestrado - Programa de Pós-Graduação em Sticto Sensu em Psicologia) - Faculdade de Filosofia, Ciências e Letras da Universidade de São Paulo

1. Cotas Universitárias. 2. Curso pré-vestibular. 3. Ensino Superior 


\section{FOLHA DE APROVAÇÃO}

Fernanda Vieira Guarnieri

Cotas Universitárias: Perspectivas de estudantes em Situação de Vestibular

Tese apresentada à Faculdade de Filosofia, Ciências e Letras de Ribeirão da Universidade de São Paulo para obtenção do título de Mestre

Área de Concentração: Psicologia

Aprovado em:

Banca Examinadora:

$\operatorname{Prof}^{0}$ Dr.

Instituição

Assinatura

Prof $^{0}$ Dr.

Instituição

Assinatura

Prof $^{0}$ Dr.

Instituição

Assinatura

Prof $^{0}$ Dr.

Instituição

Assinatura

Prof $^{0}$ Dr.

Instituição

Assinatura 
Aos meus pais, Guarnieri e Saleti, fontes inesgotáveis de amor, coragem, incentivo e sabedoria... 


\section{AGRADECIMENTOS}

Durante $\circ$ tempo em que me dediquei a esse trabalho aparentemente solitário, foi-me fundamental contar com instâncias que me aparelhassem para chegar ao final dessa etapa. Assim, teço esses agradecimentos inicialmente aos que me forneceram suporte acadêmico, seguidos dos que me ampararam (e amparam) emocionalmente em rumos incertos de um futuro próximo:

À Fundação de Amparo à Pesquisa do Estado de São Paulo (FAPESP) pela concessão da bolsa de Mestrado, fundamental para a realização deste trabalho.

Aos estudantes que aceitaram participar voluntariamente desse estudo, concebendo-nos a riqueza de suas perspectivas.

Às entidades educacionais: Colégio Vianna, Liceu Albert Sabin, Programa de Ensino Interdisciplinar Comunitário (PEIC), Escola Estadual de Ensino Médio "Otoniel Motta" e Cursinho Pré-vestibular da Universidade Federal de São Carlos - UFSCar, por permitirem a aproximação e contato com os participantes deste estudo.

À minha orientadora Lucy Leal Melo-Silva pela parceria, confiança, paciência e cumplicidade em momentos decisivos desta etapa. Também pela oportunidade de fazer parte da equipe técnica da Revista Brasileira de Orientação Profissional, que me valeu experiências significativas sobre a produção acadêmico-científica.

Aos professores Ana Paula S. da Silva e José Marcelino de R. P., julgadores do meu ingresso no Mestrado, pela credibilidade e pelas significativas contribuições para a melhoria do projeto inicial.

Aos professores Vera Lúcia Navarro e Geraldo Romanelli, pelo fornecimento de material de pesquisas no início da definição do projeto

Ao Centro de Pesquisas em Psicodiagnóstico (CPP), em especial à professora Sônia Pasian, Érika T. K. Okino, Isildinha M. S. Munhoz, Consuelo Ferreira, Fabiana H. Almeida pelas 
sugestões e auxílios prestados ao longo do projeto.

Aos colegas da Pós-Graduação Mariana L. de Barros pelo incentivo acadêmico e pessoal; e a Marcelo A. Pereira pelas considerações referentes à elaboração do questionário.

Aos meus pais, Vaoldeci Menezes Guarnieri e Maria Saleti Vieira Guarnieri pela onipresença diante da distância inexorável e pelo incentivo incondicional que me fizeram perseverar desde o início.

Aos meus irmãos Rafaela Vieira Guarnieri e Antônio Guarnieri Neto, pela coragem e pelo aprendizado que compartilhamos em tempos de difícil ausência dos nossos mentores.

A Washington Santa Rosa, pelo companheirismo e acolhimento contínuo das minhas necessidades emocionais cotidianas e também nas situações mais adversas.

Às amigas e amigos que participaram desse período de quase exílio social, pela compreensão e pelos reencontros esporádicos, mas tão reconfortantes. Em especial, a Ana Cláudia E. Fugikaha, Taciana Calmon, Mariana A. Jabur e Letícia A. M. da Silva

Aos camaradas do grupo de capoeira Senhor do Bonfim, pela extroversão e adrenalina nos momentos de maior sobrecarga das tarefas acadêmicas.

Finalmente, e acima de tudo, agradeço a Deus, pela força que me guia para conseguir aceitar o que já foi e me permite ir além. 
"Os desafios que temos adiante nos solicitam a manter viva a crítica à 'totalidade' em suas diferentes declinações, a manter vivo o amor pelas complexidades culturais, científicas e filosóficas, em radical contraste com o simplismo brutal dos monismos. Que tocasse a política, a filosofia ou a ciência, o drama mais incorrigível do século XX foi o conflito entre o pensamento da pluralidade e da complexidade de um lado, e os dogmas totalitários do outro. Uma ordem totalitária - que seja fundamentada na hegemonia de um partido, de uma classe, de uma nação ou de um sistema científico - sempre é fundamentada no ódio pelas complexidades vivas, na destruição das minorias, na unificação forçada das diversidades, na nulificação dos indivíduos, no desprezo das vocações". 


\section{LISTA DE TABELAS}

Tabela 1 - Evolução do número de matrículas no Ensino Superior Brasileiro e representação nacional em porcentagem nos estabelecimentos público e privados, de 1933 a 2001

Tabela 2 - Representação do número de matriculas no ensino superior brasileiro público e privado, por períodos, em valor absoluto (n) e em porcentagens relativas de aumento (\%) por intervalo

Tabela 3. Distribuição e freqüência de Instituições de Ensino Superior entre as cinco regiões brasileiras por modalidade administrativa

Tabela 4 - Desempenho nacional e por regiões brasileiras na prova objetiva do ENEM-2006 de acordo com o tipo de escola de ensino

médio

Tabela 5 - Distribuição dos participantes dos grupos A e B tendo a procedência dos cursos como variável central.

Tabela 6 - Distribuições relativas, em porcentagem, da população brasileira, dos estudantes do ensino superior no Brasil e dos grupos A e B deste estudo, de acordo com as categorias étnico-raciais do Instituto Brasileiro de Geografia e Estatística (IBGE).

Tabela 7 - Distribuição dos participantes de acordo com o a procedência escolar do Ensino Fundamental e do Ensino Médio, com relação ao tipo de cursinho. As categorias consideradas foram: totalmente ou maior parte em rede Pública $(\mathrm{Pu})$, totalmente ou maior parte em rede Privada (Pri) ou metade em cada rede (Pu e Pri)

Tabela 8 - Distribuição, em número absoluto e em porcentagem, do nível de escolaridade dos pais e das mães do Grupo A e do Grupo B.

Tabela 9 - Categorização e freqüência da ocupação atual dos PAIS do Grupo A

Tabela 10 - Categorização e freqüência da ocupação atual dos PAIS do Grupo B

Tabela 11 - Categorização e freqüência de resposta dada à ocupação atual das MÃES do Grupo A

Tabela 12 - Categorização e freqüência de resposta dada à ocupação atual das MÃES do Grupo B 
Tabela 13 - Distribuição das respostas por sexo e resultado do Qui-quadrado nas respostas envolvendo atitudes frente à temática vestibular.

Tabela 14 - Distribuição das respostas por sexo nas respostas dadas à questão sobre a temática relativa à oportunidade de ingresso nas universidades públicas para alunos do Ensino Médio público......

Tabela 15 - Distribuição por sexo das repostas sobre qual seria o critério mais aceito a ser incorporado a programas de Cotas Universitárias.

.......

Tabela 16 - Distribuição das respostas por sexo dadas aos itens do questionário COTAS referentes à temática das Cotas Universitárias

Tabela 17 - Distribuição das respostas por sexo dadas aos itens do questionário COTAS referentes à temática das Medidas Governamentais de acesso ao Ensino Superior.

Tabela 18 - Distribuição das respostas, de acordo com o sexo, dadas à questão sobre o principal motivo que leva a população negra a viver em piores condições que a população branca, de acordo com o

sexo.

Tabela 19 - Distribuição das respostas dadas por sexo às afirmações referentes à temática Questão Racial.

Tabela 20. Distribuição das respostas dadas às afirmações referentes à temática vestibular, por modalidade de cursinho comunitário (Grupo A) ou curso particular (Grupo B).

Tabela 21 - Opinião dos Grupos A e B com relação à questão 16, que pergunta "O que acontecerá se uma pessoa, vinda de escola pública, estudar bastante para vestibulares de universidades federais e públicas".

Tabela 22 - Opiniões de acordo com o tipo de cursinho sobre os critérios que poderiam ser melhor utilizados por Programas de Cotas Univeristária.

Tabela 23 - Distribuição das respostas dadas às afirmações referentes à temática: Cotas Universitárias, por modalidade de cursinho comunitário (Grupo A) ou curso particular (Grupo B)..

Tabela 24 - Distribuição das respostas dadas às afirmações referentes à temática Medidas Governamentais de acesso ao Ensino Superior, por modalidade de cursinho comunitário (Grupo A) ou curso particular (Grupo B).

Tabela 25 - Distribuição das respostas dadas às afirmações referentes à temática Questão Étnica e Racial, por modalidade de cursinho comunitário (Grupo A) ou curso particular (Grupo B)

Tabela 26. Freqüência de respostas dadas à questão 14, sobre o principal motivo associado à diferença entre os salários de negros e brancos no Brasil 
Tabela 27. Quadro descritivo com algumas características dos entrevistados... 


\section{LISTA DE FIGURAS}

Figura 1 - Distribuição de jovens com mais de 17 anos que Concluíram e que Não Concluíram o Ensino Médio, com relação ao total dessa população e com relação a cor ou Figura $2-$ Predição da Escolha Vocacional na Teoria Social Cognitiva de Carreira . 


\section{RESUMO}

GUARNIERI, F. V. Cotas Universitárias: Perspectivas de estudantes em situação de vestibular. 2008, 144p. Dissertação (Mestrado). Faculdade de Filosofia, Ciências e Letras de Ribeirão Preto. Universidade de São Paulo, 2008.

Este estudo focaliza as Cotas Universitárias enquanto política pública de Ação Afirmativa na Educação Superior. Por se tratar de uma implantação legislativa recente e de abranger complexas temáticas humanas, como questões étnicas, raciais e sociais, que afetam a referência identitária brasileira e pelo fato de já existirem várias instituições com programas de cotas em funcionamento, faz-se necessário acompanhar as repercussões dessas medidas em diversos segmentos da sociedade, sobretudo entre a população diretamente interessada, ou seja, os jovens que aspiram ao acesso à universidade. O presente estudo tem como finalidade investigar a opinião de um grupo de vestibulandos a respeito desse assunto. $\mathrm{O}$ estudo foi realizado em duas etapas. Na primeira, 107 estudantes matriculados em cursos pré-vestibulares, distribuídos em dois grupos: de cursinhos comunitários (Grupo A, $\mathrm{n}=53$ ) e de particulares (Grupo $\mathrm{B}, \mathrm{n}=54$ ). Os jovens responderam a um questionário contendo temas que focalizam as cotas universitárias e outros que tangenciam o objeto de estudo, como o vestibular, acesso ao Ensino Superior, questões étnicas e raciais e papel do Governo Federal no processo de implementação de medidas afirmativas. Na segunda etapa seis dos participantes foram entrevistados individualmente, sendo três de cada Grupo. A análise quantitativa deu-se mediante o tratamento dos dados obtidos por meio do Questionário, com base na estatística descritiva e a aplicação do teste Qui-quadrado. A análise qualitativa fundamenta-se na teoria sóciocognitiva de desenvolvimento de carreira com aportes da teoria das representações sociais. Os resultados mostram que em relação à implantação dos programas de cotas universitárias, 54,7\% do grupo A concorda com a implantação das cotas, enquanto $81,5 \%$ de $\mathrm{B}$ discorda. $\mathrm{O}$ grupo $\mathrm{B}$ parece mais informado sobre assunto, já que 83,3\% sabe da existência de pelo menos 14 instituições do Ensino Superior com programas de cotas, contra 67,9\% do grupo A. Sobre o Projeto de Lei Federal que institui cotas sociais e étnicas em universidades públicas, o percentual do grupo A que concorda com a implantação da medida é significativamente superior ao do grupo B (64,2\% versus $14,8 \%)$. Quanto à questão étnico-racial, a maioria dos participantes concorda que há preconceito racial contra negros no Brasil (94,3\% em A e 96,3\% em B) e que brancos e negros são tratado de maneiras diferenciadas ( $83 \%$ de $\mathrm{A}$ e $87 \%$ do grupo $\mathrm{B})$. Atribuiu-se à escravidão a causa principal da situação atual de pobreza dos negros (71,7\% em A; e $88,9 \%$ em B). Outras diferenças e semelhanças entre as opiniões dos dois grupos são analisadas e discutidas.

Palavras-chaves: cotas universitárias, curso pré-vestibular, ensino superior. 


\begin{abstract}
GUARNIERI, F. V. University Quotas: Perspectives of students preparing for university entrance examination. 2008, 144p. Dissertation (Master). Faculdade de Filosofia, Ciências e Letras de Ribeirão Preto. Universidade de São Paulo, 2008.
\end{abstract}

This study focuses on the issue of university quotas as public policy of affirmative action in higher education. Considering that this is a recent legislation and includes complex human themes, issues such as: ethnic, racial and social issues that affect the Brazilian identity reference, and because there are already several institutions offering quotas, it is necessary to monitor the impact of that type of measure on the various segments of society, especially among the people directly concerned, that is, the young people seeking entrance to university. This study aims to investigate the opinion of a group of preparation course students about it. The study was conducted in two stages. At first, 107 students registered in preparation courses, were divided into two groups: a group of community courses (group $\mathrm{A}, \mathrm{n}=53$ ) and another, consisting of private courses (group $\mathrm{B}, \mathrm{n}=54$ ). All of them answered a questionnaire containing questions that focused on the university quotas and other issues related to the object of study, such as: university entrance examination, access to higher education, racial and ethnic issues and the role of the Federal Government in the process of implementing affirmative action. In the second stage, three students from each group were interviewed individually. The data gathered from the questionnaire were analyzed quantitatively by means of descriptive statistics and application of Chi-Square Test. The qualitative analysis is underpinned by the Social-Cognitive approach of career development, with contributions from the Social Representation approach. The results showed that $54,7 \%$ of the students from Group A agreed with the quotas, while $81.5 \%$ from Group B disagreed. Group B seemed to be better informed, as $83.3 \%$ knew about the existence of at least 14 institutions of higher education offering quota programs, against $67.9 \%$ from group A. About the federal bill that establishes social and ethnic quotas in public universities, the percentage of group A who agrees with the implementation of the measure is significantly higher than that of group B (64.2\% versus $14.8 \%)$. About the ethnic-racial issue, most of the participants agree that there is a racial bias against the black in Brazil (94.3\% from A and $96.3 \%$ from B) and that whites and blacks are treated in different ways ( $83 \%$ of $\mathrm{A}$ and $87 \%$ of group $\mathrm{B})$, slavery is considered to be the main cause of black poverty (71.7\% from A and $88.9 \%$ from B). Other differences and similarities between the views of the two groups are analyzed and discussed.

Keywords: quotas university, pre-vestibular courses, higher education. 


\section{SUMÁRIO}

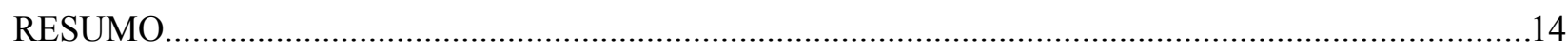

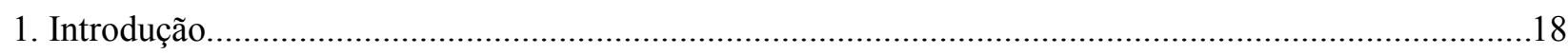

1.1. Ensino Superior Brasileiro: Um Campo de Contradições.........................................................19

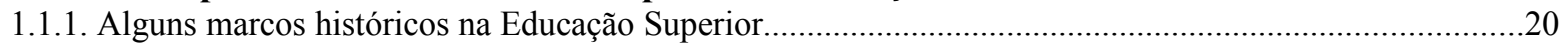

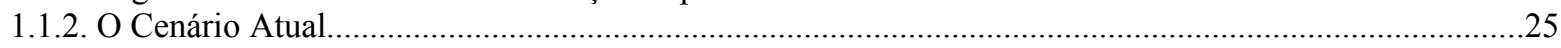

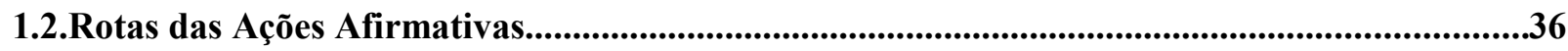

1.2.1. Ação Afirmativa: do Pioneirismo Norte-Americano aos Moldes Brasileiros..............................................40

1.3. Cotas Universitárias: Cenário Brasileiro e Organizações de Suporte............................................45

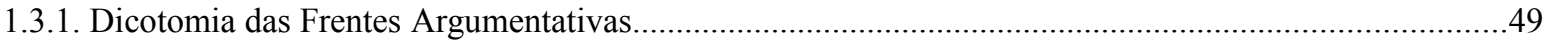

1.3.1.1. Problema social versus problema étnico-racial: dados da exclusão no ensino....................................50

1.3.1.2. Definição étnica versus mestiçagem.............................................................................................52

1.4.Vestibulandos e o Processo de Escolha Profissional ....................................................................56

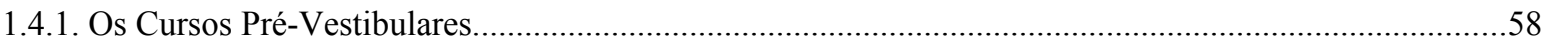

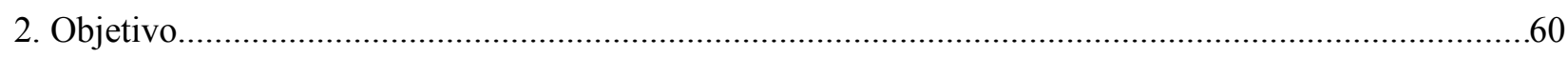

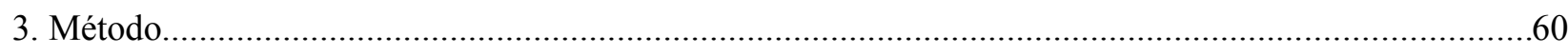

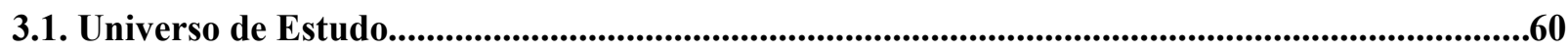

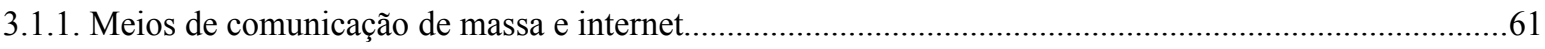

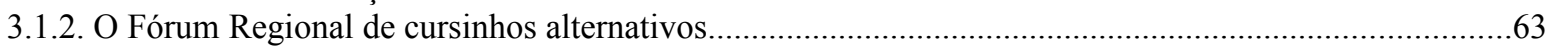

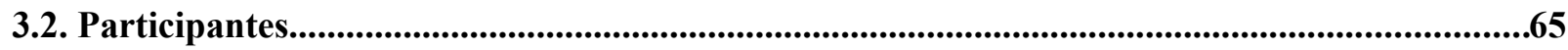

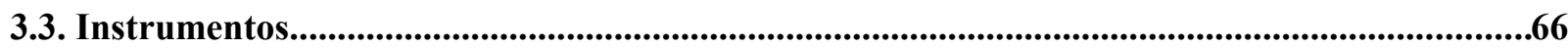

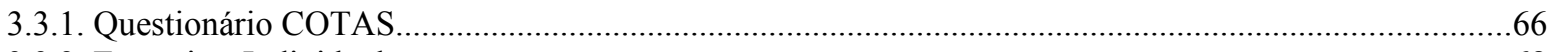

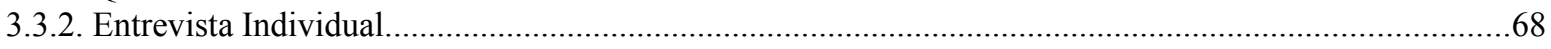

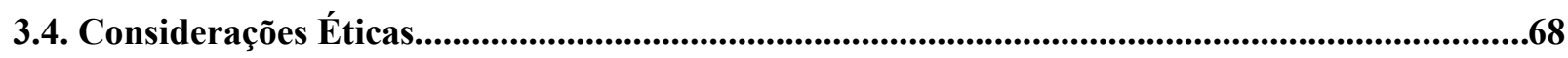

3.5. Procedimento de coleta de dados..................................................................................................69

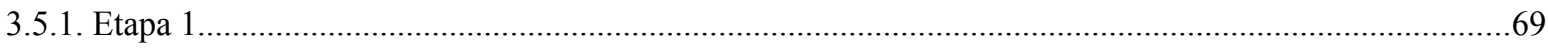

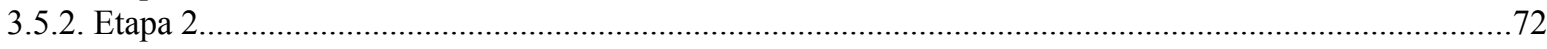

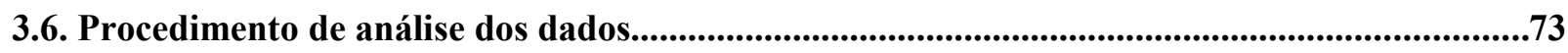

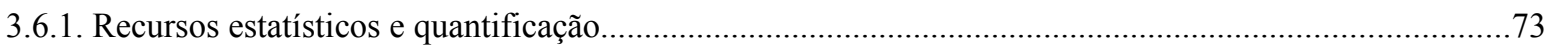

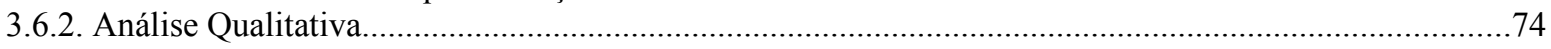

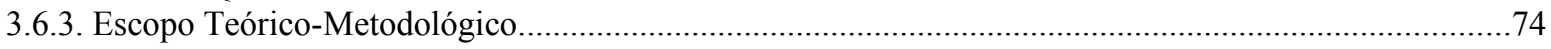

3.6.3.1. Teoria Sócio-Cognitiva de Desenvolvimento de Carreira.................................................................77

3.6.3.2. Teoria das Representações Sociais............................................................................................. 80

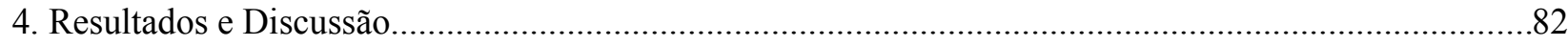

4.1. Informações Sócio-Demográficas...........................................................................................................83

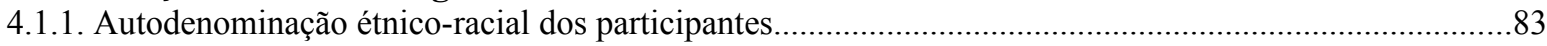

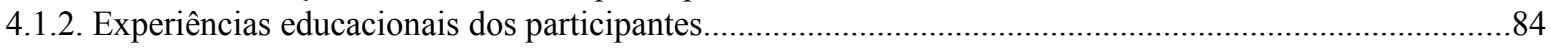

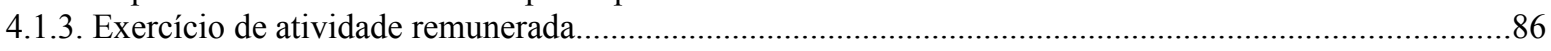

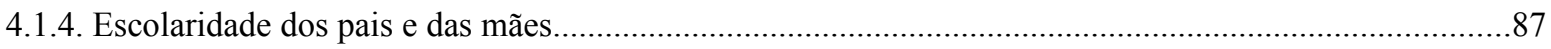

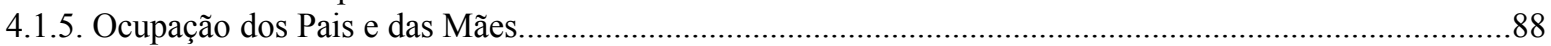

4.2. Opiniões dos Participantes com relação às Cotas Universitárias...................................................93

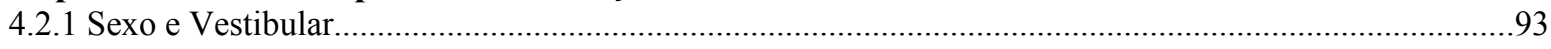




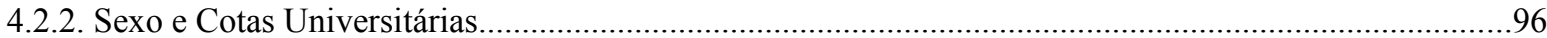

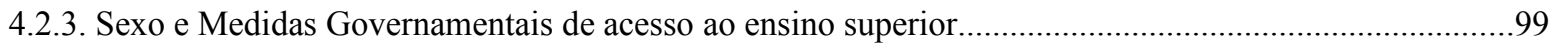

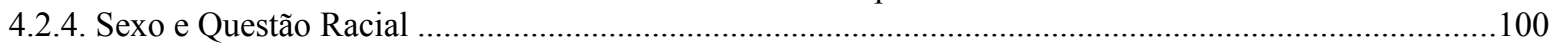

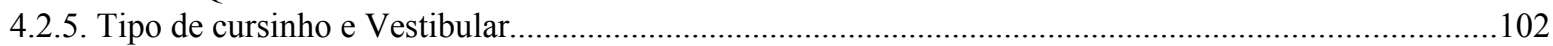

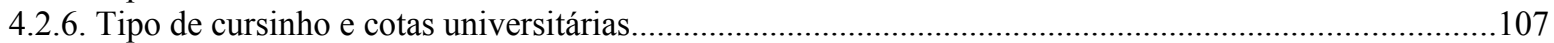

4.2.7. Tipo de cursinho e Medidas Governamentais de acesso ao Ensino Superior ..................................112

4.2.8. Tipo de cursinho e Questão Racial...............................................................................114

4.3. Comentários dos participantes sobre o Questionário COTAS...........................................118

4.4. Dados das Entrevistas..............................................................................................119

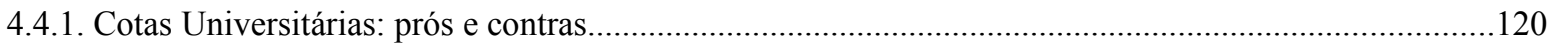

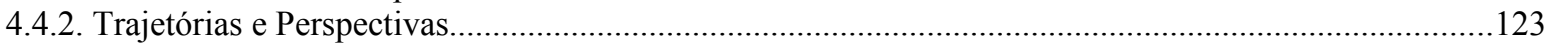

5. Considerações finais...............................................................................................

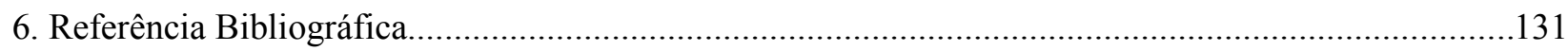

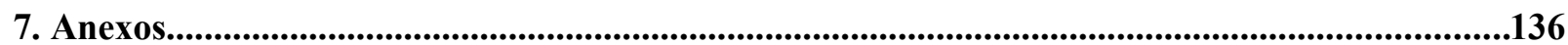

7.1. Anexo A - Modelo de Carta de Autorização para as Instituições.............................................137

7.2. Anexo B - Modelo de Termo de Consentimento Livre e Esclarecido.......................................138

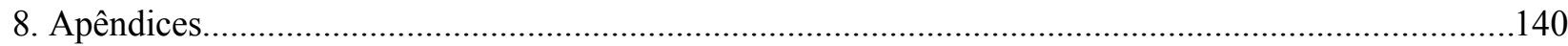

8.1. Apêndice A - Modelo do Questionário de Moehlecke (2004)....................................................141

8.2. Apêndice B - Etapas da Elaboração do Questionário COTAS.................................................145 


\section{Introdução}

No Brasil, a discussão acerca da implantação de medidas de ação afirmativa tem tido relativa abertura diante da população uma vez que tais medidas buscam formas de promover igualdade de possibilidades para grupos sociais em desvantagem. Nos dias de hoje muito se tem discutido acerca da implementação de algumas dessas estratégias voltadas à inserção de grupos com histórico de exclusão $^{1}$ e que, apesar de amplamente reivindicadas pela sociedade civil, têm sido recebidas com alguma resistência por parte de determinados setores da sociedade.

A reserva de vagas no ensino superior - as cotas universitárias - constitui um tipo de ação afirmativa que visa o acesso à universidade de pessoas em situação de desvantagem. Como toda ação afirmativa provoca polêmica, a discussão específica sobre cotas é necessária para a compreensão e aceitação destas por parte da sociedade. Ainda que haja a convicção de que toda iniciativa que favoreça a igualdade de direitos e a participação dos cidadãos na vida civil deva ser incentivada e vista com bons olhos pela sociedade, o aprofundamento em debates sobre as cotas universitárias faz emergir dúvidas que vão desde a falta de consenso sobre o papel desempenhado pelas cotas no sentido de promover justiça social, até questões étnicas mais amplas que têm sido polemizadas e rediscutidas particularmente com a implantação da reserva de vagas em algumas universidades brasileiras.

Considerando que a escolha por um curso no ensino superior reflete expectativas profissionais, e que as cotas universitárias representam um meio de flexibilização do acesso a esse nível de ensino, trata-se de uma temática de interesse no campo da orientação profissional na medida em que permite investigar as possíveis influências dessas medidas sobre as perspectivas de futuro dos jovens a curto, médio ou longo prazo. Inicialmente, no entanto, faz-se necessário, aprofundar algumas acesso a bens econômicos e/ou culturais, configurando assim seu histórico de exclusão. 
das principais problemáticas relacionadas à definição desse campo de investigação, que vai desde definições dessas ações no cenário brasileiro, desde critérios de definição dos beneficiários até aspectos ideológicos quanto à releitura da identidade nacional de culto à miscigenação.

A fim de aproximar o leitor no universo da investigação, a introdução deste estudo desdobrouse em quatro subseções, a partir dos conteúdos centrais e os conceitos evocados pela temática das cotas universitárias. A primeira subseção refere-se ao ensino superior. Inicia-se com aspectos histórico-políticos e alguns de seus desdobramentos no cenário atual, seguindo para questões pertinentes ao acesso e às representações simbólicas atribuídas a esse nível de ensino. São discutidas também problemáticas envolvendo níveis anteriores de ensino e algumas questões atuais envolvendo críticas ao modelo estrutural das universidades. A segunda centra-se sobre a temática das Ações Afirmativas, com definições recentes de teóricos desta área de investigação, trazendo considerações sobre o modelo norte-americano e seu papel histórico no desenvolvimento de um modelo específico de ações afirmativas para negros. Comenta-se a mudança de postura do governo brasileiro, o papel da sociedade civil e alguns episódios que marcaram esse processo. A terceira seção aborda as cotas universitárias propriamente ditas no seu contexto atual. São citados órgãos reguladores e modelos nacionais de funcionamento desses programas. A quarta sessão traz considerações acerca de características contextuais dos estudantes interessados em ingressar no ensino superior no Brasil. A finalidade dessa sessão é a de apresentar o universo dos atores do presente estudo, permeando alguns aspectos da condição de desenvolvimento e da escolha profissional. Essa sessão é complementada por dados referentes aos cursos pré-vestibulares.

\subsection{Ensino Superior Brasileiro: Um Campo de Contradições}




\subsubsection{Alguns marcos históricos na Educação Superior}

Algumas passagens na história política e econômica brasileira são fundamentais para contextualizar o cenário de ensino superior, desde sua origem até sua configuração nos dias atuais. Durham (2003b) refere-se à evolução e expansão do ensino superior no Brasil a partir de episódios histórico-políticos nacionais. O primeiro corresponde ao período monárquico (1808) e vai até o início da república (1889) e é marcado pela existência de Escolas autônomas para formação de profissionais liberais e eram de iniciativa da Coroa. O segundo período citado pela referida autora coincide com o da $1^{\text {a }}$ República, momento em que há descentralização do sistema, ou seja, ao lado das escolas federais surgem outras públicas (municipais e estaduais) e também as privadas. As primeiras universidades brasileiras foram criadas sob regência do Estado Novo, em 1930. De acordo com Durham (2003b), após a criação tardia das primeiras universidades, o período que correspondeu à $2^{\mathrm{a}}$ República (1945 a 1964) marcou a primeira notável expansão do ensino superior a qual ocorreu na com a queda de Getúlio Vargas, durante processo de redemocratização nacional.

A década de 1950 foi marcada por intenso fervilhar de conflitos sociais dos mais variados e pela participação crescente de estudantes universitários em lutas políticas diversas. Nas palavras de Sampaio (2002) esse período foi palco de lutas "cujo ator principal não era mais a elite intelectual, mas o movimento estudantil” (p. 11). Ainda na $2^{\mathrm{a}}$ metade dos anos 50 esse movimento centralizou-se na discussão acerca da votação da Lei de Diretrizes e Bases da Educação Nacional (LDB), em que defendiam a reforma do modelo vigente, a expansão das universidades públicas e gratuitas, associando-se o ensino à pesquisa. Reivindicavam também que todo o ensino privado fosse substituído pelas instituições públicas, visto que as universidades deveriam ser um motor para o desenvolvimento nacional, devendo também contar com a participação das classes populares na luta por igualdade social. Os dirigentes deveriam ser eleitos diretamente por professores, funcionários e 
alunos; todos os cursos deveriam ser de graduação plena, além da opção de um título de bacharelado ou profissional para o acesso a uma profissão regulamentada. Qualquer outro modelo que fugisse a esses padrões era considerado "degradante" e deveriam ser extintos. No entanto, essa lei não foi aceita: venceram os setores privatistas.

O período autoritário que se seguiu (1964 a 1985) abrangeu o Regime Militar e a reforma sinalizou a expansão do ensino superior tanto o público como o privado, de modo que o segundo desenvolve-se mais aceleradamente em razão da criação de escolas isoladas, oferta de cursos a baixo custo e menores exigências acadêmicas. Por outro lado estas instituições representaram uma ampliação efetiva tanto no número de vagas oferecidas quanto na diversificação dos cursos oferecidos. Inicia-se assim, uma concentração crescente do setor privado com relação ao público que vem se consolidando e se ampliando até os dias atuais. Tal ampliação deu-se por ocasião do desenvolvimento urbano-industrial vivenciado naquele momento o que favoreceu o aumento da demanda pela formação oferecida pelos cursos superiores para qualificação de mão-de-obra. Importante ressaltar que só a partir de 1970 a representação do setor particular supera o público, aumentando crescentemente sua participação no ensino superior (Tabela 1) e essa concentração se mantém sempre superior a $60 \%$ do total das matrículas.

Tabela 1 - Evolução do número de matrículas no Ensino Superior Brasileiro e representação nacional em porcentagem nos estabelecimentos públicos e privados, de 1933 a 2001.

\begin{tabular}{cccccc}
\hline \multirow{2}{*}{ Ano } & \multicolumn{2}{c}{ Público } & \multicolumn{2}{c}{ Privado } & Total \\
\cline { 2 - 5 } & Número & $\%$ & Número & $\%$ & Número \\
\hline 1933 & 18986 & 56,3 & 14737 & 43,7 & 43723 \\
\hline 1945 & 21307 & 52,0 & 19968 & 48,0 & 90975 \\
\hline 1960 & 59624 & 56,0 & 42067 & 44,0 & 35691 \\
\hline 1965 & 182696 & 56,2 & 142386 & 43,8 & 425478 \\
\hline 1970 & 210613 & 49,5 & 214865 & 50,5 & 1377286 \\
\hline 1980 & 492232 & 35,7 & 885054 & 64,3 & 1540080 \\
\hline 1990 & 578625 & 37,6 & 961455 & 62,4 & 1759703 \\
\hline 1995 & 700540 & 39,8 & 1059163 & 60,2 & 2694245 \\
\hline 2000 & 887026 & 32,9 & 1807219 & 67,1 & 3039754 \\
\hline 2001 & 939225 & 31,0 & 2091529 & 69,0 & \\
\hline
\end{tabular}

Fonte: NUPES / SAMPAIO (2002) 
Destaque desse período foi que em cinco anos (de 1965 a 1970) houve um aumento de matriculas no nível superior de ensino da ordem de 206\% no setor público e $239 \%$ no particular (Tabela 1). De acordo com a tabela 2, os maiores aumentos de matriculas referentes ao ensino público, ao privado e ao Total foram foi nos intervalos: 1945 a 1960; 1960 a 1965; e 1970 a 1980. Nos dois primeiros intervalos houve aumento da demanda por mão-de-obra qualificada em função do desenvolvimento urbano industrial. O terceiro foi marcado pela expansão de Estabelecimentos Isolados principalmente no setor privado, que passaram de 463 em 1970 para 643 em 1980, enquanto a quantidade de universidades particulares variou de 15 para 20 nesse mesmo intervalo. Quanto ao setor público, no mesmo período, aumentou de 139 para 178 Estabelecimentos Isolados, e de 32 para 35 universidades.

No final dos anos 80, após a expansão sem precedentes da década anterior, o ensino superior encontra-se já bastante modificado como o aumento de matriculas e das modalidades alternativas ao padrão ideal de ensino superior estruturado na LDB e inicia um período de estagnação da educação superior. Um destaque desse período foram os cursos noturnos principalmente de iniciativa privada, como alternativa para atender uma demanda de estudantes já inseridos no mercado de trabalho. Apesar de ampliar o acesso ao nível superior de ensino a uma parcela da população que de outra forma não poderia atingir tal graduação, cabe mencionar que o nível de exigência desses cursos era menor, o que de acordo com Durham (2003b) facilitou o ingresso dessa população. Em 1986, correspondiam às matriculas em cursos noturnos $76,5 \%$ das Instituições Privadas versus $16 \%$ das Universidades Federais. 
Tabela 2 - Representação do número de matriculas no ensino superior brasileiro público e privado, por períodos, em valor absoluto (n) e em porcentagens relativas de aumento (\%) por intervalo.

\begin{tabular}{ccccccc}
\hline \multirow{2}{*}{ Intervalo } & \multicolumn{2}{c}{ Público } & \multicolumn{2}{c}{ Privado } & \multicolumn{2}{c}{ Total } \\
\cline { 2 - 7 } & $\mathrm{n}$ & $\%$ & $\mathrm{n}$ & $\%$ & $\mathrm{n}$ & $\%$ \\
\hline $1933 / 1945$ & 2321 & 12,2 & 5231 & 35,5 & 7252 & 21,5 \\
\hline $1945 / 1960$ & 38317 & 179,8 & 22099 & 110,7 & 54716 & 133,5 \\
\hline $1960 / 1965$ & 123072 & 206,4 & 100319 & 238,5 & 256405 & 268,0 \\
\hline $1965 / 1970$ & 27917 & 15,3 & 72479 & 50,9 & 73382 & 20,8 \\
\hline $1970 / 1980$ & 281619 & 133,7 & 670189 & 311,9 & 951808 & 223,7 \\
\hline $1980 / 1990$ & 86393 & 17,5 & 76401 & 8,6 & 162794 & 11,8 \\
\hline $1990 / 1995$ & 121915 & 21,1 & 97708 & 10,2 & 219623 & 14,3 \\
\hline $1995 / 2000$ & 186486 & 26,6 & 748056 & 41,4 & 934542 & 34,7 \\
\hline $2000 / 2001$ & 49199 & 5,5 & 284310 & 13,6 & 345509 & 11,4 \\
\hline
\end{tabular}

Fonte: NUPES / SAMPAIO (2002)

Ainda quanto o acesso à educação superior, é importante ressaltar que mesmo no auge do crescimento do ensino superior à taxa bruta de matriculas em relação à população de 20 a 24 anos não superou $12 \%$, ou seja, os obstáculos estruturais do próprio sistema de educação brasileiro já funcionavam como um gargalo que excluía quase $90 \%$ dos candidatos a uma vaga no ensino superior.

Curiosamente dos anos 80 e 90 verificou-se no país escassez de candidatos aos exames vestibulares (DURHAN, 2003b), em função da absorção da demanda reprimida de egressos do ensino médio, promovida pela criação de cursos noturnos, especialmente, nas instituições particulares. Assim, a desvantagem das instituições particulares de ensino superior de pequeno porte tanto com relação às universidades públicas, que possuíam maior autonomia para criação de cursos novos, quanto aos grandes estabelecimentos privados que possuíam maior número de cursos e poderiam enfrentar melhor novas demandas, todo esse cenário conspirou para o acirramento entre as instituições particulares de pequeno porte pela disputa por demandas alternativas.

Assim, a partir de 1985 o movimento de expansão do ensino superior privado norteia-se pelo ensino de massa - mass private sector - com finalidade lucrativa, sem que haja intenção quer do 
desenvolvimento de atividades de pesquisa, quer de qualificação do corpo docente. É nesse contexto que se insere a Associação Nacional dos Docentes Universitários (ANDES), movimento formado por docentes do ensino público de caráter contestatório que se contrapõe ao modelo insurgente de modelo particular de ensino superior. As grandes bandeiras do movimento foram: autonomia e democratização. Apesar de conseguir o apoio de grupos de esquerda da universidade, tal movimento diferenciou-se do movimento estudantil que era fundamentado por lutas sociais, já que os docentes representavam a nata intelectual, haviam sido excluídos politicamente e buscavam nos limites da universidade alterar esse quadro ambicionando alianças com funcionários e o alunado. Dessa forma um novo grupo se mobiliza contra a ANDES. Tratava-se então de um grupo de pesquisadores universitários envolvidos com estudos temáticos sobre a universidade, realizados na Europa e nos EUA, fortemente influenciados pela mudança de postura do Estado: de executor para regulador e avaliador. Assim, introduziram-se questões sobre: autonomia e avaliação.

De 1995 a 2002 inicia-se o período recente (DURHAM, 2003b), que coincide com os dois mandatos do Presidente da República Fernando Henrique Cardoso (FHC). Foi marcado por modificações substanciais em políticas educacionais, especialmente no que diz respeito ao ensino fundamental que praticamente se universalizou, sendo favorecidos pelo incentivo governamental ao acesso, permanência e sucesso. Conseqüências desse tipo de políticas favoreceram o aumento explosivo de matriculas no ensino médio, contribuindo para o aumento de uma futura demanda por ensino superior e, conseqüentemente esse processo marcou a retomada do crescimento no referido nível de ensino. Com relação à formação docente, uma tendência iniciada anteriormente à década de 90 teve continuidade nesse período: o aumento do percentual de docentes com titulação de Mestre ou Doutor.

Os esforços do período que vai de 1995 a 2002 foram em grande parte de regular e avaliar o ensino superior. Em 1996 foram introduzidas inovações importantes no âmbito da Nova LDB, dentre as quais: exigiu-se que as universidades - só então fiscalizadas por órgãos governamentais - 
associassem ensino e pesquisa como requisito para o credenciamento e recredenciamento da instituição; exigiu-se uma qualificação mínima do corpo docente - um terço dos docentes formados por mestres e doutores e um terço deveriam permanecer em tempo integral na universidade; recredenciamento periódico; renovação periódica do reconhecimento dos cursos superiores; criou-se uma ferramenta para efetivar a avaliação do ensino superior em que consistiu o exame nacional de cursos - Provão.

Ainda em relação a essa LDB, a Educação Superior constitui-se por cursos seqüenciais, cursos de graduação, pós-graduação e cursos de extensão. De acordo com Instituto Nacional de Estudos e Pesquisas Educacionais (INEP), o Sistema de Educação Superior brasileiro é composto pelos seguintes tipos de instituições: universidades, centros universitários, faculdades, institutos superiores e centros de educação tecnológica. Em relação ao tipo de administração, as Instituições de ensino superior (IES) dividem-se em públicas (como é o caso das instituições federais, estaduais e municipais) e privadas. Dentre as públicas, as federais são mantidas e administradas pelo Governo Federal; as estaduais, pelos Governos Estaduais e as municipais pelo poder público municipal. Já as instituições privadas de ensino superior, podem ser com ou sem fins lucrativos. No primeiro caso são as denominadas instituições particulares em estrito senso. Já nos casos onde não há fins lucrativos, tais entidades privadas podem ser instituídas por cooperativas e por professores, com finalidade de incluir representantes da comunidade; ou serem do tipo confessional; ou ainda filantrópicas - com finalidade de complementar as práticas governamentais (MEC, 2006). O termo ensino superior refere-se, neste estudo, à formação curricular que sucede o ensino médio, em específico o ensino acadêmico universitário.

\subsubsection{O Cenário Atual}


No Brasil, existem hoje 2435 instituições de ensino superior em funcionamento, sendo que de 2002 para 2006 a proporção de instituições particulares no cenário do ensino superior aumentou de 60\% (SAMPAIO, 2002) para 76,7\% (Tabela 3). A distribuição do total das instituições de ensino superior nas cinco regiões brasileiras, segundo o INEP (2006), dá-se da seguinte forma: 48,7\% na região sudeste; $18 \%$ na região nordeste; $16,7 \%$ na região sul; $10,7 \%$ na região centro-oeste; e 5,8\% na região norte. Em todas as regiões há predomínio de instituições privadas: centro-oeste (92,7\%); sudeste (90,3\%); sul $(90,2 \%)$; norte $(87,3 \%)$; e nordeste $(85,4 \%)$.

Tabela 3. Distribuição e freqüência (em valor absoluto e em porcentagem) de Instituições de Ensino Superior entre as cinco regiões brasileiras (SE, CO, NE, N, S) por modalidade administrativa (Privada ou Pública Federal, Estadual e Municipal).

\begin{tabular}{ccccccccc}
\hline & & SE & CO & NE & N & S & Total & $\%$ \\
\hline \multirow{3}{*}{ Pública } & Privada & 1069 & 241 & 374 & 124 & 366 & 1864 & 76,7 \\
\cline { 2 - 9 } & Federal & 42 & 10 & 26 & 13 & 14 & 177 & 7,3 \\
\cline { 2 - 9 } & Estadual & 43 & 4 & 20 & 4 & 19 & 241 & 9,9 \\
\cline { 2 - 9 } & Municipal & 31 & 5 & 20 & 1 & 7 & 397 & 16,3 \\
\hline
\end{tabular}

Fonte: INEP, 2006.

É sabido que o desenvolvimento econômico está diretamente relacionado ao nível educacional de determinadas regiões. Assim, a população terá maior ou menor acesso à educação qualificada, em todos os níveis, dependendo do local de origem, da sua família ou da possibilidade de migração de alguns de seus membros em busca de progresso educacional, social e econômico, os seja, de maior autonomia.

No âmbito da sociedade contemporânea, o acesso à vida acadêmica assume uma forma representativa de êxito da autonomia. "Na mente das pessoas comuns controlar o fluxo de influência não traz propriamente os prazeres da dominação, mas a oportunidade de assumir o controle de si mesmo" (SENNETT, 2001, p.159). Ser autônomo na sociedade atual é ser livre, ser dono de si e de suas vontades, de modo que o acesso ao ensino superior vai de encontro a essas necessidades. Esse 
conceito de liberdade é permeado por uma relação de forças do indivíduo autônomo sobre os que reconhecem essa autonomia.

A autonomia assume formas simples e complexas. A forma simples é a posse de qualificações. A sociedade moderna é rotulada, vez por outra, de 'sociedade das especializações', em vista de sua valorização da habilidade técnica. A forma complexa da autonomia está voltada para uma estrutura de caráter, estrutura de caráter autônomo significa uma pessoa com capacidade de ser um bom juiz das outras, por não ansiar desesperadamente pela aprovação delas (SENNETT, 2001, p.118).

Nesse sentido, o acesso à universidade traz implicações sociais na medida em que é entendido como mecanismo que promove autonomia pessoal podendo repercutir em mobilidade e ascensão sociais futuras. “(...) o campo educacional influi fortemente nas perspectivas futuras de participação social e de acesso às posições melhor remuneradas do mercado de trabalho" (DURHAM, 2003a, p.01). No entanto, ainda que a formação universitária seja bastante prestigiada enquanto escolha profissional, ainda é acessível a uma pequena parcela da população, mais especificamente aos egressos do ensino médio mais bem preparados e treinados para os exames seletivos das concorridas instituições públicas e também para os que possuem condições para financiar estudos em instituições particulares.

O instrumento mais utilizado na seleção para essas vagas é o vestibular, exame de admissão à universidade, que divide os estudiosos acerca da sua real finalidade e objetivos. Há os que defendem que o vestibular mede a preparação, as competências e habilidades necessárias para o bom desempenho no ensino superior (DURHAM, 2003a). Outros, porém entendem que o vestibular se interpõe como um tipo de barreira que não mede nada além da habilidade e treino para fazer o exame per se, o que pode ser desenvolvido por cursos preparatórios que existem com essa finalidade.

Existe demanda, mas há simultaneamente o efeito gargalo que exclui a maioria dos candidatos a esse nível de ensino, uma vez que para se valer dos "benefícios" provenientes do ingresso na universidade, os candidatos a uma vaga devem passar por uma série de procedimentos que justifiquem sua entrada na instituição de ensino. Petruccelli (2004) aponta para dois tipos de 
demanda: a demanda potencial, formada por estudantes que conseguiram concluir o ensino médio; e a demanda efetiva composta por aqueles com maiores possibilidades dar continuidade aos estudos. Tal condição é determinada mais diretamente por condições sócio-econômicas (renda, tempo para dedicação aos estudos, etc). Quanto ao primeiro tipo, Petruccelli (2003) traz dados referentes àqueles que concluíram o ensino médio - que estejam freqüentando ou não uma universidade - e os que não concluíram o nível médio.

Como mostra a Figura 1, do total da população com idade acima de 17 anos, 81,4\% (cerca de 88 milhões) não concluiu sequer o ensino médio; e dentre os 18\% (20 milhões) o concluiu (demanda potencial), sendo que desses apenas 2,8\% (3 milhões) freqüenta algum curso universitário. Isso indica que o acesso às universidades ainda é uma realidade que exclui a quase totalidade dos egressos do ensino médio. Acrescenta-se que o aumento desses egressos é encorajado por estratégias nacionais de educação, o que já a priori deflagra uma inflação ainda maior dessa demanda potencial que caso não seja de alguma forma absorvida pelo mercado ou encarada com seriedade poderá acarretar subdesenvolvimento da população economicamente ativa. 


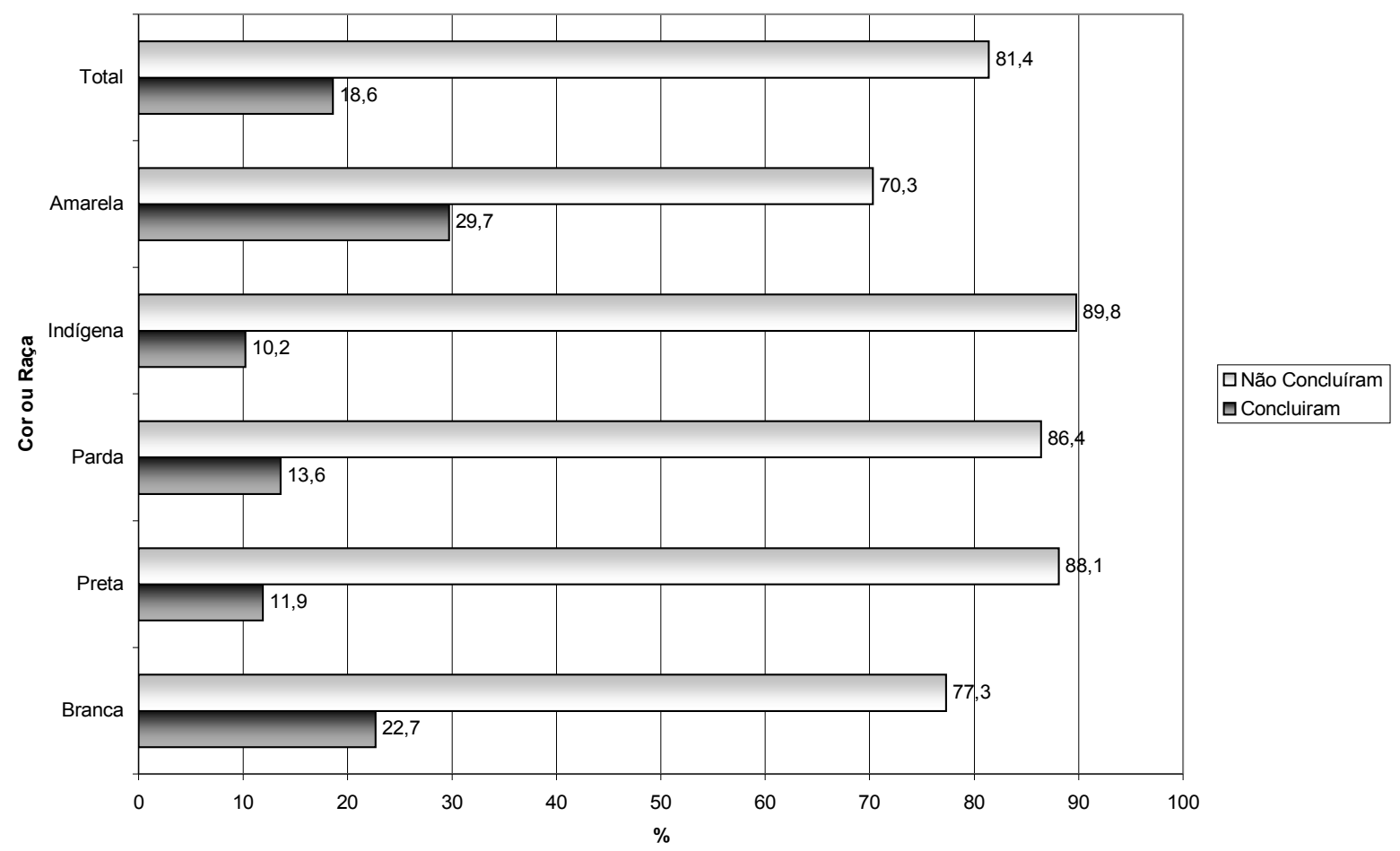

Figura 1. Distribuição de jovens com mais de 17 anos que concluíram e que não concluíram o ensino médio, com relação ao total dessa população e com relação à cor ou raça.

Em termos étnico-raciais, cabem aqui algumas considerações. Dentre os concluintes de ensino médio (18\% do total), $67,6 \%$ são de cor branca; $4,3 \%$, de cor preta; $26,5 \%$, de cor parda; $0,2 \%$ são indígenas; e $0,9 \%$ são de cor amarela. Dentre os poucos 2,8\% (3 milhões de brasileiros) que conseguem atingir o nível universitário, distribuem-se etnicamente entre 79\% que se autodenominam de cor branca; $16,8 \%$ parda; $2,4 \%$ preta. No entanto é em relação à composição étnico-racial do território brasileiro que o mapeamento da cor dos estudantes do ensino superior chama atenção: há na população cerca de 44,6\% de negros (denominação resultante da soma das denominações parda e preta, ambas instituídas pelo IBGE utilizadas na literatura), enquanto nas universidades esse índice não chega a $20 \%$. Já os brancos compõem $53,6 \%$ da população, mas representa quase $80 \%$ do perfil dos universitários. É esse um dos aspectos centrais que vem sendo questionado por medidas de ação afirmativa voltadas ao ensino superior brasileiro. 
Como relação à formação desses egressos de ensino médio, é recorrente a associação entre o tipo de preparação recebida (se pública ou privada) e desempenho (sucesso ou fracasso) no vestibular. De acordo com Whitaker e Onofre (2006) existe uma representação popular negativa com relação ao ensino fundamental e médio públicos que encontra sustentação no enfoque de pesquisas científicas há mais de 40 anos. Tal dado reforça a crença popular de que a formação no ensino fundamental e Médio das escolas privadas parece preparar melhor a criança e o adolescente para etapas posteriores nas instituições de ensino. No entanto esse dado não se confirma na realidade, pois o investimento em cursinhos se faz necessário mesmo para essa clientela (WHITAKER \& FIAMENGUE, 1999).

Dados do Exame Nacional de Ensino Médio (ENEM), expressos na Tabela 4, confirmam essa tendência, indicando que o desempenho dos estudantes que cursaram em rede particular (o ensino médio totalmente e, ou a maior parte), com uma média geral $(=46,2)$ superior à media geral nacional $(=36,9)$, atingindo a maior nota no Sudeste $(=48,5)$, seguida pela atingida no Sul $(=46,2)$ e Centro-Oeste $(=44,1)$.

Tabela 4 - Desempenho nacional e por regiões brasileiras na prova objetiva do ENEM-2006 de acordo com o tipo de escola de ensino médio

\begin{tabular}{ccccccc}
\hline & $\begin{array}{c}\text { Média } \\
\text { Geral } \\
(\mathrm{MG})\end{array}$ & $\begin{array}{c}\text { Estudantes } \\
\text { da rede } \\
\text { Particular } \\
(\mathrm{Pa})\end{array}$ & $\begin{array}{c}\text { Estudantes } \\
\text { da rede } \\
\text { Pública (Pu) }\end{array}$ & $\begin{array}{c}\text { Diferença entre } \\
\text { Pa e MG }\end{array}$ & $\begin{array}{c}\text { Diferença entre } \\
\text { Pu e MG }\end{array}$ & $\begin{array}{c}\text { Diferença } \\
\text { entre Pu e Pa }\end{array}$ \\
\hline BRASIL & 36,9 & 46,2 & 35,9 & 9,3 & $-1,0$ & $-10,3$ \\
\hline Norte & 32,2 & 39,9 & 32,3 & 7,7 & $-0,1$ & $-9,6$ \\
\hline Nordeste & 33,8 & 42,2 & 32,9 & 8,4 & $-0,5$ & $-9,2$ \\
\hline Centro-Oeste & 35,5 & 44,1 & 35,0 & 8,6 & $-1,3$ & $-11,0$ \\
\hline Sudeste & 38,9 & 48,5 & 37,5 & 9,6 & $-0,2$ & $-7,6$ \\
\hline Sul & 38,7 & 46,2 & 38,6 & 7,5 & & \\
\hline
\end{tabular}

Entre os que cursaram do Ensino Médio público (totalmente ou a maior parte do tempo) 
apresentaram-se desempenhos menos favoráveis sendo que a média geral desses estudantes $(=35,9)$ ficou abaixo da media nacional $(=36,9)$. As maiores notas atingidas foram no $\operatorname{Sul}(=38,7)$, seguidas pelo Sudeste $(=37,5)$ e Centro-Oeste $(35,0)$. A diferença entre as médias dos desempenhos dos estudantes de escola particular e os de escola pública no ENEM salienta a discrepância nos desempenhos desses dois grupos de estudantes (rede particular e rede pública), sendo que com relação à média nacional, os alunos da rede particular superarem em 10,3 pontos os de escola pública. Em todos os estados essa diferença foi maior do que 7,0 pontos, chegando a 11,0 pontos no Sudeste.

De acordo com as categorias por faixas de desempenho do referido exame ${ }^{2}$, os estudantes de escola pública tiveram em todas as regiões brasileiras desempenho de insuficiente a irregular (de 0 a 40 pontos). Já os de escola particular alcançaram médias na faixa de regular a bom (de 40 a 70 pontos). No entanto, tratar comparações desse tipo de maneira descontextualizada e sem que sejam consideradas particularidades institucionais de cada escola sem a devida cautela pode - a partir da manipulação do fazer científico - desvirtuar a complexidade dos fatores abarcados pelo processo avaliativo do referido exame. É necessário atentar para os modelos pedagógicos existentes e quais têm sido eficazes na formação educacional de estudantes e cidadãos. No universo das instituições particulares, o Instituto Dom Barreto, em Teresina (PI) foi avaliado como a melhor escola do país, com a maior nota total (prova objetiva e redação), no ENEM de 2006, com a pontuação 74,71. Ainda que a região Sudeste seja hegemônica na eleição realizada pelo ENEM (em 2006 concentrou 14 das 20 melhores escolas do país eleitas pelo ENEM em termos educacionais e pedagógicos) o fato de uma escola na região nordeste ter assumido o primeiro lugar do ranking, chama atenção para escolas de qualidade também em outras regiões. A justificativa para o bom desempenho revelado no Piauí consistiu na interação de sucesso entre investimento na formação de professores, carga horária de aulas mais extensa, turmas pequenas e infra-estrutura com laboratórios específicos para cada

2. Avalia-se o desempenho dos estudantes em três faixas de desempenho de acordo com o intervalo de notas, a saber: de Insuficiente a Regular, (de 0 a 40 pontos); de Regular a Bom (de 40 a 70 pontos); e de Bom a Excelente (de 70 a 100 pontos). 
disciplina, o que fez desta escola referência nacional. Apesar de se tratar de uma escola particular, a mensalidade do ensino médio ( $\mathrm{R} \$ 498$ ) equivale a um terço do valor pago pelo mesmo nível de ensino em grandes capitais como São Paulo (R \$1500), além disso, a instituição mantém compromisso social com a comunidade, abrigando cerca de 160 crianças carentes e uma escola para 280 alunos da educação infantil ao ensino médio, ambas na periferia de Teresina (BRITO, 2007).

Com relação ao ensino superior brasileiro, é também inevitável a comparação entre instituições privadas versus públicas, havendo de maneira recorrente o embate entre intelectuais e estudantes contra o ensino privado e em defesa da universidade pública (DURHAM, 2003b) na literatura produzida no Brasil sobre o assunto. Pontos cruciais como a ausência de liberdade acadêmica nas instituições particulares, além da apropriação da autonomia concedida pelas mantenedoras e proprietários do ensino superior privado apontam essa tendência. Aspectos como a educação massificada, proletarização dos docentes - ganho por hora aula, pouco incentivo para formação continuada dos mesmos dentro da própria instituição, além de serem por vezes submetidos a demandas impostas pelos donos das instituições de ensino - reforçam a crença popular que valoriza o ensino superior público. Desse modo, o ensino básico da rede privada priorizaria o preparo para ingresso no ensino superior público de qualidade, nas carreiras de maior prestígio e nas melhores faculdades. No entanto, uma perspectiva crítica deve questionar a predileção atribuída à preparação do ensino médio particular para o sucesso no ensino superior de qualidade, a luz do fenômeno "efeito cursinho", termo cunhado por Whitaker (1988). De acordo com esse fenômeno, investiga-se se há influência positiva da complementação dos estudos por meio de cursinhos no desempenho final dos vestibulares, condição que vem se traduzindo na opção mais recorrente de egressos do ensino médio aos chamados cursinhos aos que visem atingir níveis superiores de educação. Dessa forma, pode-se considerar que o tipo de formação oferecida pelo ensino médio não prepara o jovem para dar continuidade aos estudos, sendo insuficiente para garantir o sucesso no vestibular tanto de egressos da rede pública quanto aos da rede particular. Portanto, para que não haja divulgação infundada acerca 
da qualidade das instituições públicas e privadas de ensino, é necessário o acompanhamento de ambas para que possam ser levantados pontos para discussão que situem o contexto nacional de educação em suas especificidades regionais. Um importante dado - já referido anteriormente - sobre da realidade brasileira é a caminhada maciça de egressos do ensino médio público rumo ao ensino superior privado, que oferece 89,5\% (INEP, 2006) das vagas nesse nível de ensino. Dessas vagas, grande parte corresponde ao período noturno, cursos mais acessíveis ao perfil de estudantes em situação econômica limitada que dividem o tempo de estudo com atividade assalariada (SAMPAIO, 2002). Nesse sentido, os cursos noturnos e alguns diurnos desempenham um papel social importante enquanto alternativa de ingresso nas universidades. Whitaker e Fiamengue (2003) complementam que apesar de se poder associar o trabalho a um obstáculo para a transição em níveis superiores de escolaridade, deve-se considerar outras associações que permeiam essa relação como, por exemplo, o tipo de curso, a concorrência da carreira pretendida, a região, os talentos e características individuais dos candidatos, além do tipo de trabalho realizado.

Dessa forma, é fundamental que a população reflita sobre as questões levantadas acerca das divergências e desigualdade de oportunidades para que sejam propostas alternativas podendo ser discutidas e implementadas ações a fim de tornar mais igualitárias as condições de ingresso nas universidades. No entanto, deve-se considerar a interação de tais flexibilizações de acesso com dois fenômenos que caracterizam o cenário brasileiro no âmbito da formação superior: de um lado, há pouco dinamismo na criação de oportunidades de trabalho; do outro, as exigências de mercado são cada vez maiores a respeito da qualificação de pessoal (SAMPAIO, 2002). Ou seja, da mesma maneira que formas alternativas de acesso estão sendo avaliadas é importante atentar para os efeitos e repercussões do aumento desse tipo de mão-de-obra que se tornará disponível na sociedade e como serão absorvidas. Nesse sentido, faz-se necessário trazer à pauta alguns dos principais desafios atuais colocados às instituições de ensino superior.

Afirmações que apontam o ensino superior como solução milagrosa para problemas sociais 
crônicos da sociedade brasileira são recorrentes nos meios de comunicação de massa. No entanto a crise institucional por qual vem passando o modelo atual de universidade tem problematizado tal questão. Desse modo, igualdade de acesso à universidade garantida pelo mérito e esforços individuais dos exames vestibulares são postos em discussão buscando-se assim que a configuração atual do ensino superior seja rediscutida levando-se em conta os desafios colocados pelas exigências da sociedade e os limites da intervenção destas instituições no cenário social. O levantamento de tais questionamentos busca desnaturalizar idealizações recorrentes no imaginário coletivo acerca das universidades, aproximando-a do universo sócio-cultural e histórico em que se dão as interações e práticas humanas. Uma questão colocada por Pires (1997) refere-se ao ponto crítico do papel formador da educação superior, a qual deve abarcar não apenas a profissionalização como também a formação plena do indivíduo em interação com a sociedade:

É claro que em alguns momentos deste processo educacional, especialmente no que diz respeito à formação profissional, a aprendizagem de habilidades, práticas e ações imediatas são necessárias, mas o que aqui se quer destacar [...] é que o processo educacional é mais amplo, não se esgota na dimensão prática, exige a construção da formação em sua totalidade, tem que contribuir para a formação de homens plenos, plenos de humanidade (PIRES, p. 91).

Para Santos (2005) a crise institucional das universidades configura-se em um desafio para o futuro dessas instituições, devendo-se, a partir de sua práxis (interação entre teoria e prática), aprofundar estudos que pontuem dialeticamente as teias de significações atribuídas a essas instituições no imaginário social. A referida crise institucional configura-se enquanto principal reflexão trazida ao debate envolvendo o papel das universidades no cenário mundial. Ou seja, a rigidez tanto institucional quanto organizacional contribuem para o acirramento das contradições internas da universidade tornando-a uma instituição em cheque na medida em que não seja capaz de superar os desafios impostos pela nova realidade do mundo globalizado e suas demandas cada vez mais desafiadoras. Dados dessa rigidez são ressaltados em um estudo retrospectivo realizado por Santos (2005). De acordo com esse autor, dados de pesquisas realizadas em 1982 confirmam a 
dificuldade estrutural da universidade de se submeter a modificações uma vez que das 85 instituições que já existiam no mundo em 1520 com funções semelhantes às que desempenham hoje, 70 são universidades. Karl Jaspers (apud SANTOS, 2005) em 1923, definiu como sendo a missão eterna da universidade "lugar onde por concessão do Estado e da sociedade uma determinada época pode cultivar a mais lúcida consciência de si própria”.

Em 1965 Santos (2005) definiu os três principais objetivos da universidade por ordem de relevância: (1) investigação; (2) a universidade deve ser um centro de cultura disponível para a educação do homem em geral; e por fim (3) ela deve ensinar e, também, em termos de aptidões profissionais deve se voltar para a formação integral do homem. Mesmo após as pressões feitas à universidade na década de sessenta, tais objetivos perduraram, ainda que de maneira mais abstrata: investigação, ensino e prestação de serviços. E, em 1982 pouco parece ter se modificado, como o estudo realizado por Ortega \& Gasset (1982) que elencaram quatro principais objetivos da universidade: (1) transmissão de cultura; (2) ensino das profissões; (3) investigação científica; e (4) educação dos novos homens da ciência. Cabe acrescentar que o enfoque de tais pressões verteu-se para a preocupação com a elitização da universidade e com o fim a que eram destinados os conhecimentos produzidos por tais Instituições.

Em 1987 (SANTOS, 2005) atribuiu-se à universidade 10 funções principais, cujas contradições internas caracterizaram a situação crítica de desajustamento dessa instituição na tentativa de adaptar-se ao cenário contra-sensual da pós-modernidade. Tais funções se mantêm nos dias atuais: (1) educação geral pós-secundária; (2) investigação; (3) fornecimento de mão-de-obra qualificada; (4) educação e treinamento altamente especializados; (5) fortalecimento da competitividade da economia; (6) mecanismo de seleção para empregos de alto nível por meio de certificação; (7) mobilidade social para os filhos e filhas de famílias operárias; (8) prestação de serviços à região e à comunidade local; (9) paradigmas de aplicação de políticas nacionais (por ex. igualdade de oportunidades para mulheres e minorias raciais); e (10) preparação para os papéis de 
liderança social.

Nesse contexto, é em ressonância com algumas funções atribuídas à universidade, como as referentes à mobilidade social, a aplicações de políticas públicas de igualdade, racial, por exemplo, e a preparação para os papéis de liderança social, que se demandam ações efetivas dessa instituição sobre o funcionamento de normas e condutas sociais. Assim, a reivindicação por ações afirmativas, além de outras formas de ampliação do acesso às universidades, visa intervir sobre a seletividade de tais exames que se antes eram compreendidos em termos exclusivamente meritocráticos, hoje vêm sendo re-interpretados ao partir do crivo socioeconômico.

\subsection{Rotas das Ações Afirmativas}

As Ações Afirmativas têm como objetivo a promover o acesso a meios fundamentais de sobrevivência digna, como educação e trabalho, a minorias étnicas, raciais ou sexuais. A justificativa para esse tipo de intervenção é a de que do modo como vem sendo feito o acesso determinados grupos sociais estão excluídos total ou parcialmente destes meios (GUIMARÃES, 1997). As ações afirmativas objetivam corrigir tais mecanismos. Por um tempo determinado privilegiam-se os que estão em situação de desvantagem em busca do equilíbrio. O tempo de duração dessas medidas varia de acordo com seus propósitos ou da situação em que se pretende intervir. Trata-se basicamente, de medidas de caráter social para o favorecimento da igualdade de oportunidades e que teriam como objetivo final colocar todos os membros de uma determinada sociedade independentemente do grupo a que pertença e a partir de posições iguais, em condição de participar da competição pela conquista do que é vitalmente mais significativo, (MOEHLECKE, 2004).

No âmbito internacional, as investigações acerca de ações afirmativas voltadas para o ensino superior são ainda bastante incipientes. Moehlecke (2004) constatou que mesmo nos EUA, depois de 
mais de 30 anos de vigência das políticas sensíveis a aspectos étnico-raciais no ensino superior, apenas a partir dos anos 90 foram realizados estudos sobre o impacto dessas políticas nesse nível de ensino.

Por sua vez, Guarnieri \& Melo-Silva (2007) identificaram três linhas de pensamento ou unidades de análise que permearam a dinâmica da discussão sobre ações afirmativas no ensino superior, a partir da revisão na literatura no período de 2000 a 2005, em duas bases de dados Scopus e Jstor. O referido estudo de revisão da literatura, do tipo estado da arte, analisa o corpo de conhecimento já construído a respeito da temática das cotas universitárias. Os dados foram organizados em três unidades de análise (BARDIN, 1977): (1) pensamento dicotômico contra ou $a$ favor; (2) exploração de conceitos de diversidade e (3) reflexões dialéticas. A primeira é marcado pela exposição de teorias e hipóteses direcionadas unilateralmente, ora por oposição, ora por defesa das ações afirmativas nas universidades; na segunda, há exploração de conceitos positivos sobre diversidade, caracterizada pela valorização dos efeitos humanos positivos atribuídos ao cultivo e valorização da diferença; e os estudos organizados na terceira categoria focalizam reflexões dialéticas, definidas como produções reflexivas e críticas sobre as ações afirmativas, sendo abordadas em uma perspectiva mais integrada sobre as conseqüências positivas e negativas da implantação de ações afirmativas nas universidades. Com base nas referidas unidades de análise, as autoras traçam caminhos da discussão nos EUA e no Brasil. No caso norte-americano, a seqüência das unidades de análise são de 1 para 2. Já no Brasil essa ordem equivale de 2 para atualmente 1. A unidade 3 é uma tendência futura, mas ainda bastante incipiente que implicaria no avanço das discussões das demais linhas de pensamento (GUARNIERI; MELO-SILVA, no prelo).

Em função do pioneirismo norte-americano no uso de ações afirmativas caracterizadas como raciais, não raro, estudos realizados nos Estados Unidos são utilizados como referência para a compreensão histórica da intervenção governamental, por meio de ações afirmativas, para enfrentar à segregação racial. No entanto, para efeito de comparação, devem ser salientadas as peculiaridades de 
implantação dessas medidas de acordo com o contexto sócio-histórico de cada país. Cabem algumas considerações históricas sobre o processo norte-americano e que serão comparadas posteriormente com o caso brasileiro.

Nos EUA a escravidão extinguiu-se em 1863, durante a guerra de Secessão, e já em 1865, período denominado "Reconstrução", aprovaram-se medidas contra a segregação racial do país e determinando a plena cidadania aos afro-americanos, garantindo também o direito de voto (emendas $\mathrm{n}^{\circ} 14$ e $\left.\mathrm{n}^{\circ} 15\right)$. Tais medidas encontraram bastante resistência civil, principalmente no sul do país, onde em 1869, permitiu-se a criação de leis estatais que separassem grupos raciais com a condição de que fossem criadas também acomodações para os grupos em questão. A participação da sociedade americana foi fundamental atuando firmemente nas movimentações sociais da década de 60 naquele país, tanto favoráveis quanto contrárias à segregação.

Dentre os que se opunham a medidas de integração racial pode-se citar o "Manifesto Sulista" que repercutiu na criação dos "Conselhos dos Cidadãos" que se organizaram para reforçarem, com apoio do governo, a oposição à integração entre estudantes negros e brancos (MOEHLECKE, 2004). Em 1865 surge a Ku-klux-klan (KKK), extremo da violência atingida pela prática do racismo. Tratava-se de uma sociedade secreta racista norte-americana formada por homens que utilizavam capuzes cônicos e longos mantos brancos. Eram contrários à integração entre brancos e negros e defendiam os interesses da supremacia branca (RECCO, CATARIN \& BANDOUK). As ações da KKK eram especialmente contra negros, mas também abrangiam em menor escala simpatizantes de afroamericanos - brancos, judeus, católicos, hispânicos e quem mais se posicionasse contrariamente aos interesses da aristocracia sulista. A prática de terror manifestava-se em desfiles seguidos por paradas com manifestações racistas e, até em linchamentos, espancamentos e assassinatos, passando ainda por incêndios de imóveis e destruição de colheita. Em 1922 a KKK tornou-se numerosa atingindo cerca de um milhão de membros, chegando decadentes em meados da crise de 1929, mas retomando suas forças em 1960, em oposição ao governo democrata de integração racial. Foi 
duramente combatida pelo governo de Lyndon Johnson (1963-1969). Apesar da luta do congresso norte-americano para extinguir a atuação da KKK, as manifestações racistas ainda se fazem presentes em diversas regiões do país.

Já os movimentos contrários à segregação racial eram encabeçados geralmente por lideranças negras, além de representações diversas que defendiam direitos universais, nos moldes democráticos modernos. Tratava-se de uma minoria negra norte-americana unida pelos mesmos ideais de conquista da igualdade e justiça raciais, com divergências sobre o tipo de estratégias utilizadas para se chegar a tais objetivos. A National Association for the Advancement of Colored People (NAACP), por exemplo, foi um movimento civil que questionava o sistema segregacionista norte-americano. Destaca-se na luta contra o racismo os líderes negros como Martim Luther King (1929-1968) e Malcom X (1925-1965) sendo que a principal diferença entre essas duas lideranças era que enquanto Martin Luther King apostava em uma resistência pacífica como arma para enfrentar o racismo, Malcolm X defendia a separação das raças, a independência econômica e a criação de um Estado autônomo para os negros. Além disso, surgem organizações como os "Panteras Negras" e a "Nação Islã", ambas utilizando-se de atos mais agressivos e por vezes violentos para conquistas igualitárias para os afro-americanos.

Desse modo, a definição dicotômica dos que eram favoráveis e dos que eram contrários a ações integradoras dos direitos civis - típica de modelos modernos de democracia - estabeleceu também a luta por espaços simbólicos de representação e poder que necessariamente influiriam sobre as leis de dominação vigentes até então. Estava, portanto desenhado um palco em que reivindicações de movimentos sociais por integração racial, universalização de direitos e do acesso ao ensino chocavam-se com o conservadorismo de uma maioria avessa a mudanças no status quo. Formava-se assim um sangrento cenário de luta pela alternância dos espaços ético-político, social, econômico e mesmo físico entre brancos e negros na sociedade norte-americana. Assim, a história da implementação de políticas de ação afirmativa na Educação Superior nos EUA tem sua rota definida 
em função dos problemas raciais vividos pelos norte-americanos. A história brasileira é outra, como será apresentada na seção seguinte.

\subsubsection{Ação Afirmativa: do Pioneirismo Norte-Americano aos Moldes Brasileiros}

No Brasil, o segregacionismo embora não declarado, é cultuado socialmente de maneira silenciosa, mas não menos cruel. Historicamente, o Brasil passou por um longo período de 300 anos regido pelo sistema escravista, sendo que as ações abolicionistas do Governo brasileiro não privilegiaram o mínimo suporte à massa negra despejada na sociedade brasileira, sendo destituída de sentido pelo novo sistema baseado na mão-de-obra assalariada de imigrantes europeus. A discriminação racial no Brasil encontra meios informais de propagação e é dificilmente assumida. Assim, embora o ideal de multi-racialidade brasileira corrobore uma postura nacional vanguardista de referência para estudos internacionais (MAFFESOLI, 2002), o que tem chamado atenção é a forma como outra frente ideológica vem se opondo a esta concepção, voltando-se para definições étnico-raciais como início de um processo que enfatiza o reconhecimento e a exposição do "racismo à brasileira" e suas conseqüências negativas sobre a democratização de oportunidades. Somente a partir de 1990 as idéias acerca da implantação de ações afirmativas no Brasil tornaram-se mais expressivas e persuasivas nos meios de comunicação de massa e rodas de discussão. Esse fenômeno se deu, em grande parte, pela mudança de postura do governo brasileiro, regido na época pelo presidente Fernando Henrique Cardoso, o que favoreceu modificações no tipo de ação política, no discurso oficial e que conseqüentemente norteou a busca da essência das desigualdades étnico-raciais concebidas na prática, mas negadas no discurso apaziguador da diversidade racial (HTUN, 2004). Assim, pode-se entender a incorporação crescente de ações afirmativas para afrodescendentes como interação de mobilizações de frentes do movimento negro, da insurgência mais expressiva dos 
movimentos multiculturais e da mudança de postura ético-política do Estado brasileiro: "O processo pode, portanto ser modelado como processo dialético entre mobilização social e iniciativa presidencial, construída juntamente ao desdobramento de eventos internacionais" (HTUN, 2004, p. $62)$.

Nesse sentido, anteriormente a essa mudança de postura nacional, havia maior preocupação em se manter a cumplicidade nas relações colorblind (BOLLINGER, 2003) ou de indistinção de cor. Tal preocupação, assimilada por discursos modernos universalistas ou por imposição estratégica governamental, vem sendo cada vez mais questionada a partir da realidade social brasileira. Referese aqui a uma aceitação recíproca da existência de uma ambígua passividade / pacificidade na relação entre brancos e negros. São discursos sustentados por pensamentos vanguardistas que se posicionam em favor da mistura de cores e raças para a formação de uma sociedade "miscigenada". No entanto cabe ressaltar, como apontado por Htun (2004), que o papel assumido historicamente pelos governos brasileiros em se absterem da responsabilidade diante da discriminação racial teve repercussões negativas por dificultar a formação de uma sociedade autoconsciente e com iniciativa para ação coletiva.

The racial democracy thesis [...] insists that the disproportionate impoverishment of blacks and their absence among elites is due to class discrimination and the legacy of slavery, and that the absence of state-sponsored segregation, a history of miscegenation, and social recognition of intermediate racial categories have upheld a unique racial order (HTUN, 2004, p.64).

Existe, portanto uma grande e histórica resistência brasileira em tratar da definição racial e do racismo para justificar as desigualdades nítidas entre oportunidades de negros e brancos na sociedade. Apresentam-se assim, discursos que culpabilizam os níveis sociais por tais disparidades. Trata-se, portanto de um recurso dissociativo entre relações sociais e relações raciais, descomprometendo-se o viés racial / étnico da estratificação da sociedade brasileira. Em decorrência de tais questões étnicoraciais, cumpre refletir sobre como se deu a o desenrolar do processo de concepção e implementação 
das medidas compensatórias, no cenário brasileiro, levando-se em consideração o contexto interno, regido pela Constituição de 1988 e o externo, marcado pela Conferencia de Durban, na África em 2001.

Segundo a Constituição Brasileira de 1988, as políticas de intervenção relacionadas à garantia de direitos individuais têm caráter universalista, isto é, são destinadas à população em geral; e não são de caráter redistributivo, como é o caso das políticas diferencialistas, que privilegiam o recorte socioeconômico e envolvem ações direcionadas a grupos específicos a partir de critérios de sexo, raça, etnia e outros, como é o caso das ações afirmativas.

Políticas de igualdade racial como a ação afirmativa, ao exigirem direitos coletivos e a identificação racial dos grupos beneficiados, perturbam não apenas a noção moderna de igualdade e justiça, segundo o qual a distribuição de bens e posições sociais seria baseada no indivíduo e em seus méritos e talentos naturais, mas também a ideologia brasileira de mestiçagem e da democracia racial, constitutiva de nossa identidade e unidades nacionais onde não haveria espaço para divisões ou diferenciações de raça. (MOEHLECKE, 2004, p.03).

Pode-se compreender a ênfase dada a ações políticas denominadas diferenciais como tendência da atualidade, com o objetivo claro de renúncia ao modelo anterior de universalização de direitos que pelos moldes liberais e neoliberais (configuração social, econômica e política) não cumpriu sua finalidade, já que não foi acessível a todos. Para Gonçalves e Silva (2006) essa é uma tendência que tem orientado a ação de grupos que não encontraram eco no referencial hegemônico ocidentalizado proposto pelos ideais da Modernidade e que buscam no reconhecimento de suas peculiaridades a criação de uma referência multi-representativa, positiva e inclusiva. Trata-se de um movimento denominado multiculturalista, que originalmente expressava-se à maneira de reivindicações de grupos étnicos e, que a partir da segunda metade do século XX são expressivos também das reivindicações de minorias mais amplas (por exemplo, homossexuais, mulheres, etc.). A reação desses grupos culturalmente dominados dá-se por meio de suas organizações políticas que visam o reconhecimento e respeito quanto aos seus direitos civis. 
É marca de um momento histórico-político de transição o resgate de questões ainda não superadas para sejam reeditadas na atualidade. Essa tendência à reavaliação de conceitos, no caso das cotas universitárias, remete entre outras problemáticas à busca por diferenciação racial e étnica de negros e indígenas no Brasil tida até então como uma composição étnica indiferenciada, fundida à noção de mestiçagem instituída historicamente no Brasil e tida aparentemente como questão resolvida.

Assim, a Constituição Brasileira (1988), diante da questão racial brasileiros posiciona contra a secção étnica, repudiando o termo "raça" como critério de distinção. Parte-se do princípio de que os objetivos da República Federativa do Brasil estão na promoção do bem de todos, sem que haja preconceitos de origem, raça, sexo, cor, idade e quaisquer outras formas de discriminação, valendo-se de princípios universalistas (BRASIL, 2005). A referida mudança de postura anti-racial associada à Conferência de Durban, em 2001, repercutiu em propostas de "ações afirmativas" para a população afro-descendente, entre elas o reconhecimento oficial da legitimidade de reparações para com os efeitos sociais da escravidão. "É preciso reconhecer que um mergulho na história social do Brasil mostra que durante a escravatura formou-se uma poderosa cultura racista" (IANNI, 2004, p.11). Nesse sentido, alguns dos movimentos negros vêm se organizando a mais de 30 anos, buscando - a partir das ações afirmativas - tentativas de fortalecimento e engrandecimento da etnia negra no Brasil, aniquilada tão fortemente desde o início da colonização.

A ideologia da 'democracia racial' aparece como um elemento complicador da situação do negro [...]. Representa uma falácia que serve para encobrir as práticas racistas existentes no território nacional e isentar o grupo branco de uma reflexão sobre si mesmo (CAVALLEIRO, 2000, p. 28).

No Brasil, a proposta das cotas surgiu a partir do Grupo de Trabalho Interministerial (GTI) criado pelo Ministério da Justiça em 1995, criado por decreto no governo FHC, cujo intuito era o de valorização da População Negra, reunindo representantes da sociedade civil e do Governo Federal. Esse GTI representou um passo decisivo para a discussão e aproximação das populações negras no 
âmbito da Administração Pública.

Definem-se, então, as cotas como ação afirmativa inserida no âmbito das políticas públicas de flexibilização de acesso da população negra a vagas de emprego, a cargos políticos e ao ensino superior. A partir disso, pôde-se desenvolver um conceito sobre as políticas de ação afirmativa para negros como sendo ações adotadas tanto pelo setor público quanto pelo privado que buscam compensar perdas históricas significativas mediante a flexibilização do acesso, da capacitação, do emprego e preservação da auto-imagem nos meios de comunicação. O grande problema foi traduzir tal medida para a prática, que ao se transformar em meta, trouxe a necessidade de ser representada em termos de uma porcentagem específica. A dificuldade relativa à definição dessa porcentagem trouxe e ainda traz desentendimentos mesmo entre os que apóiam a medida. A atenção recai sobre os problemas étnicos ainda existentes no Brasil que foram de certa forma "deixados de lado".

Como já referido, o contexto internacional contribuiu fortemente para mudanças na política brasileira, como a ocorrida em 2001: uma visível mudança da postura de combate ao preconceito adotada pelo governo brasileiro depois da III Conferência Mundial das Nações Unidas de Combate ao Racismo, Discriminação Racial, Xenofobia e Intolerância Correlata, ocorrida em Durban, na África do Sul. De acordo com o subdiretor geral para Ciências Humanas e Sociais da UNESCO, Pierre Sane (2002), o que diferenciou a terceira Conferência das duas anteriores, realizadas ambas em Genebra, foi o reconhecimento de que a escravidão é um crime contra a humanidade (lesa-humanidade) e que o racismo está presente nas sociedades contemporâneas em geral. Até então se referia a esse fenômeno em contextos específicos, como no caso do apartheid e do sionismo. Depois da Conferência em Durban assumiu-se que o racismo "é uma realidade em todas as sociedades e que constitui grave ameaça para a segurança e a estabilidade dos países" (Sane, 2002).

Enfrentar essa realidade conduziu ao exame de causas históricas, socioeconômicas e culturais do racismo, noções que passaram a nortear as mais diferentes pesquisas no âmbito das ações diferenciais, medidas compensatórias e ações afirmativas. Nesse sentido, ao final do evento foi 
desenvolvido um Plano de Ação em que se estabeleceram estratégias a partir da cooperação internacional e do fortalecimento das nações e de mecanismos para "o combate ao racismo, a discriminação racial, a xenofobia e intolerância correlata e, ainda, apontou para o estabelecimento de recursos e medidas eficazes de reparação, ressarcimento, indenizações e outras medidas em níveis nacional, regional e internacional" (IKWA, PIOVESAN, ALMEIDA \& GOMES, 2006).

Por fim, acrescenta-se que hoje existem variadas formas de ações afirmativas focadas no ensino superior, como por exemplo, o Programa Universidade para Todos (PROUNI) - que concede bolsas de estudos em cursos de graduação em instituições privadas; o Programa de Financiamento Estudantil (FIES) - destinado ao financiamento da formação acadêmica de estudantes regularmente matriculados em Instituições particulares e que não possuam condições financeiras para tal; há também os cursos pré-vestibulares alternativos e comunitários, que buscam preparar jovens desprovidos de recursos financeiros para os exames vestibulares; além das cotas universitárias que serão discutidas a seguir.

\subsection{Cotas Universitárias: Cenário Brasileiro e Organizações de Suporte}

As cotas universitárias no Brasil inserem-se no cenário da educação superior brasileira, que tem se mostrado um campo cada vez mais fértil para implantação de medidas diferenciais. São medidas voltadas para grupos sociais específicos e que ampliam as possibilidades de acesso ao ensino superior sendo uma intervenção direta sobre esse nível de ensino além de evidenciar a reedição do mito da democracia racial brasileira. A reivindicação por cotas interfere diretamente sobre os exames vestibulares que se eram compreendidos em termos exclusivamente meritocráticos, tendo privilegiado o preparo de estudantes detentores de maior capital econômico e cultural.

Existe hoje no Brasil um número crescente de instituições de ensino superior implementando 
sistemas de reserva de vagas. No primeiro semestre de 2005, havia 14 instituições de ensino superior que já haviam implantado programas de cotas. Já no segundo semestre de 2006 esse número aumentou para 43 instituições. Destas, 69,7\% são particulares e distribuem-se da seguinte forma: $41,8 \%$ localizam-se na região sudeste; $18,6 \%$ na região centro-oeste; $18,6 \%$ na região nordeste; $18,6 \%$ na região sul; e 4,6\% na região norte. $\mathrm{O}$ aumento significativo em apenas um ano da implementação das cotas étnico-raciais e, ou sociais nesse nível de ensino confirmam a relevância de estudos direcionados para a investigação dessa temática. Ressalta-se, portanto, que há necessidade de acompanhar tais programas tanto no processo de inserção dos alunos na universidade quanto permanência e saída para o mercado de trabalho, de modo que lhes sejam assegurados permanência e acolhimento tanto para lidar com dificuldades relacionadas à formação escolar, assimilação de conteúdos das aulas e a restrições financeiras, quanto para questões tangenciais acerca das relações étnico-raciais e sociais, considerando a aceitação dessas medidas entre os próprios universitários.

Entre os programas de cotas já implementados no Brasil, há uma grande variedade de critérios, como: étnicos (voltada para os povos indígenas), raciais (relacionado a afrodescendência), étnico-raciais (para afrodescendentes e indígenas), sociais (para egressos da rede pública e, ou avaliados de acordo com a renda familiar), regional (prioridade de ingresso a estudantes da região da universidade em questão). Há ainda os programas de reserva de vagas mais complexos que mesclam mais de dois critérios. Seguem alguns exemplos de programas em funcionamento.

O Rio de Janeiro foi o primeiro Estado brasileiro a legislar (Lei no 3708, novembro de 2001) e decretar (Decreto $\mathrm{n}^{\mathrm{o}}$ 30.766, março de 2002) um programa de cotas que se fundamenta de acordo com as leis estaduais 1.258/2000 e 3.524/2000. A Lei Estadual do Rio de Janeiro de $n^{\circ} 1.258 / 2000$ prevê a reserva de $50 \%$ das vagas em universidade pública para alunos egressos da rede pública de Ensino Fundamental e Médio. A Lei $\mathrm{n}^{\circ} 3.524 / 2000$ concebe a reserva de 40\% das vagas da Universidade Estadual do Rio de Janeiro (UERJ) e da Universidade Estadual do Norte Fluminense (UENF), para alunos de descendência afro ou indígena. Cabe ressaltar que se criou, paralelamente à implementação 
do programas de cotas no Rio de Janeiro, projetos com a finalidade de fornecer suporte ao grupo de alunos cotistas. Ou seja, tais projetos, como por exemplo, o "Projeto Espaços Afirmados", visavam garantir a permanência e o desenvolvimento acadêmico qualitativo desses alunos.

Outra importante referência para o cenário brasileiro em termos de implementação institucional de reserva de vagas é a Universidade Federal da Bahia (UFBA), uma das pioneiras no estudo sistematizado de questões étnico-raciais anteriores à implantação da reserva de vagas (UFBA, 2004). Essa universidade se valeu de estudos riquíssimos realizados pelo grupo de pesquisa "A cor da Bahia" certificado pelo CNPq e criado em 1992 com objetivos de (1) realizar pesquisas empíricas sobre o negro no Brasil sob a perspectiva de comparação internacional; (2) apoiar a formação dos estudantes (graduação e pós-graduação) nos estudos sobre as relações étnicas e raciais no Brasil; (3) implementar ações que visem à democratização do ensino superior no Brasil (GUIMARÃES, 1991). O modelo desenvolvido por esta universidade é um dos mais complexos, pois apresenta - de acordo com o site da UFBA seis categorias de reserva de vagas: (1) aos egressos de escola pública que se declararam pretos ou pardos (36,55\% das vagas); (2) aos candidatos de escola pública de qualquer etnia ou cor $(6,45 \%)$; (3) aos de escola particular que se autodeclararam pretos ou pardos (caso categorias anteriores não preencham as vagas); (4) os candidatos de escola pública que se declararam índios-descendentes $(2 \%)$; (5) a todos os candidatos, qualquer que seja a procedência escolar e a etnia ou cor (55\%); e (6) Aos candidatos de escola pública que se declararam índios aldeados ou moradores das comunidades remanescentes dos quilombos, sendo que são abertas duas vagas extras por curso para esse fim.

Em 2004 foi elaborado um projeto de Lei Federal (n $\left.n^{\circ} 3627 / 2004\right)$ para instituir o Sistema Especial de Reserva Vagas para estudantes que tenham cursado o ensino médio em escola pública e em especial para negros e indígenas nas instituições públicas federais de Educação Superior. A priorização étnica desses povos se dá pela justificativa de que as vagas não são preenchidas por negros e membros das comunidades indígenas em função de "insuficiências circunstanciais" desses 
grupos (BRASIL, 2004a). A porcentagem das vagas reservadas para cada etnia estará de acordo com a composição étnica da população estadual de acordo com o Instituto Brasileiro de Geografia e Estatística (IBGE), ou seja, haverá percentuais mínimos para negros e indígenas que estarão de acordo com o perfil da população da unidade da Federação onde está a universidade, segundo o último censo IBGE (BRASIL, 2004b).

Tão importante quanto atentar para a criação de alternativas de inserção é o acompanhamento das práticas implementadas. Nesse sentido, julga-se importante citar algumas das organizações que oferecem suporte a iniciativas de políticas que visam à democratização do ensino superior. $\mathrm{Na}$ América Latina pode-se citar como exemplo o Observatório latino-americano de políticas educacionais (OLPED), que consiste em um espaço multidisciplinar voltado para pesquisa, análise, divulgação e documentação envolvendo as políticas educacionais latino-americanos. As informações estão disponíveis via internet (http://www.lpp-uerj.net/olped/) e são destinadas a professores, estudantes, sindicalistas, militantes e ativistas de movimentos sociais, além de acadêmicos e pesquisadores. As atividades desenvolvidas pelo OLPED fundamentam-se no compromisso com a educação pública, a democratização do Estado e a construção de uma sociedade humana e solidária.

No Brasil há organizações de referência no que tange o suporte à aplicação de ação afirmativa no Ensino Superior (MEC, 2006). São algumas delas: o Laboratório de Políticas Públicas (LPP) e o Programa Políticas da Cor na Educação Brasileira (PPCor) e a entidade Educação e Cidadania de Afrodescendentes e Carentes (EDUCAFRO). O LPP foi criado em março de 2000 pela reitoria da universidade do Estado do Rio de Janeiro (UERJ) com finalidade de desenvolver atividades voltadas à pesquisa, análise e apoio a políticas públicas de caráter democrático (AE 006/Reitoria/2000, 15-03-2000). As suas principais atividades consistem em discutir, monitorar e formular estratégias governamentais que promovam o espaço público como esfera de realização efetiva dos direitos cidadãos. Mais especificamente o LPP desenvolve um programa de pesquisas multidisciplinares, além de seminários e cursos de formação na gestão e avaliação de políticas públicas. A segunda 
organização citada - PPCor - foi criada em 2001 pelo referido LPP e tem se fortalecido como uma referência nacional na luta pela promoção das políticas de ação afirmativa no campo educacional brasileiro. Corresponde hoje ao maior programa de ações afirmativas desenvolvido no âmbito das universidades brasileiras. Esse programa constitui-se enquanto rede de iniciativas orientadas para ampliar tanto as oportunidades de acesso quanto à permanência de afro-brasileiros no Ensino Superior. No início os esforços do PPCor enfatizavam o fortalecimento dos projetos em curso, além da avaliação de novas ações orientadas a diminuir os efeitos segregacionistas de crivo sócio-raciais no acesso ao Ensino Superior. Já a EDUCAFRO consiste em uma rede de cursinhos pré-vestibulares comunitários com o objetivo de reunir voluntários que lutem pela inclusão de negros e de estudantes com dificuldades financeiras nas universidades públicas, prioritariamente, ou em universidades particulares, por meio de bolsas de estudos.

\subsubsection{Dicotomia das Frentes Argumentativas}

O debate sobre a temática das cotas divide a população e os cientistas sociais. A questão é ainda bastante controversa e repleta de ambigüidades, quanto maior a elaboração teórica discursiva e a coesão dos discursos, maiores as dificuldades em se localizar as construções ideológicas cada vez

mais sofisticadas por utopias limítrofes de posicionamentos "universais modernos" versus “diferenciais pós-modernos".

Paradoxalmente à defesa dos próprios interesses e do arsenal semântico e simbólico que compõem a vivência histórica do sujeito e o preparam para enfrentar diferentes situações cotidianas, as cotas trazem outro lado denunciador de uma vigência de valores incompatíveis com uma realidade competitiva e atroz aos que não estiverem adaptados a um modelo hegemônico que precisa ser revisto. A seguir são apresentadas algumas linhas gerais referentes aos principais embates mediados 
pela discussão acerca das cotas universitárias no Brasil.

\subsubsection{Problema social versus problema étnico-racial: dados da exclusão no ensino}

De início, a estratégia de separar a característica "social" e "étnica" das cotas, sustenta a relação estabelecida por Munanga (2004b): “ambigüidade entre cor e classe social (...) como uma das características do racismo brasileiro". Algumas reflexões que emergem dessa tendência questionam a necessidade de ação afirmativa para afrodescendentes, já que cientificamente é possível afirmar que não existem diferenças genéticas capazes de definir quem é branco ou negro (FRY; MAGGIE, 2004). No entanto, reconhece-se que ainda assim o processo discriminatório acompanha o negro e se mantém desde o início da formação escolar, ou seja, apesar do avanço de pesquisas com o genoma humano, o que se percebe na prática é que o preconceito racial permanece, ainda que cruelmente silencioso. Não se trata da condição biológica, mas da função representativa e simbólica do estigma associado ao negro, o que isso representa e quais os significados atribuídos desde o período da colonização até os dias atuais. Nesse sentido, e de acordo com Munanga (2004a), "os conceitos de negro e de branco têm um fundamento étnico-semântico, político e ideológico, mas não um conteúdo biológico" (p.52). No contexto da educação questiona-se que tipo de interferências esse estigma introjetado nas condutas interpessoais pode ter no âmbito escolar.

Estudos realizados acerca do desempenho dos alunos no ensino brasileiro têm chamado a atenção para a defasagem na escolaridade de negros do ensino fundamental ao superior. De acordo com Araújo e Araújo (2003), dados do Sistema de Avaliação da Educação Básica (SAEB) indicam que a participação de crianças negras na última série do ensino médio (24\%) representa metade (50\%) da registrada na $4^{\mathrm{a}}$ série do ensino fundamental (56\%). Já entre brancos a proporção de crianças na $4^{\mathrm{a}}$ série é de $44 \%$, subindo para $76 \%$ na última série do ensino médio. Alunos negros freqüentando escolas apresentam sistemática queda de desempenho acadêmico. Mesmo nas escolas particulares, os rendimentos escolares de brancos e negros são destoantes. Um exemplo citado pelo referido estudo 
indica que na $4^{\mathrm{a}}$ série da rede particular, nas provas de leitura, alunos negros alcançam um score de 179, e os alunos brancos 228 pontos. Em relação ao ensino superior, dados do IBGE (dezembro de 2003) evidenciam a discrepante distribuição de vagas universitárias entre negros (negros e pardos) e brancos. De acordo com esse levantamento $82,3 \%$ do contingente de estudantes brasileiros de graduação é formado por brancos. Já entre os brasileiros que tenham concluído o ensino superior, apenas $14,3 \%$ são negros. Outro dado importante foi o de que essa proporção se mantém quase inalterada em comparação ao censo de 1991, ainda que na última década tenha ocorrido o maior aumento de universitários da história do Brasil. Isso quer dizer que a desigualdade racial no ensino superior permanece praticamente inalterada, ou seja, que os negros e os pardos no Brasil possuem uma participação muito pouco significativa no ensino superior ainda que representem uma parcela considerável da população.

Ribeiro (2006) investigou se pessoas originárias de classes sociais distintas e de diferentes grupos étnicos teriam oportunidades desiguais de mobilidade ascendente. Concluiu-se que homens brancos, pardos e pretos, oriundos de classes sociais mais baixas (trabalhadores rurais, pequenos empregadores rurais, etc), possuem chances semelhante de ascenderem socialmente, ou seja, pode-se dizer que nos estratos sociais mais baixos, brancos e afrodescendentes enfrentam as mesmas dificuldades para ascenderem socialmente. No entanto, no topo da hierarquia de classe brasileira, os brancos possuem maiores chances de ascenderem e os negros de descenderem. Enfim, afirma-se que existe desigualdade nas oportunidades de mobilidade social entre brancos e afrodescendentes. Em síntese, o estudo revela que "a desigualdade de oportunidades está presente no topo da hierarquia de classe, mas não na base desta hierarquia" (p.32). Outro ponto abordado pelo autor refere-se ao fato de que a escolarização é ainda um dos principais fatores que influenciam positivamente a mobilidade social, destacando a importância de se analisar as desigualdades de oportunidades educacionais. No mesmo estudo, utilizaram-se seis transições educacionais para que fosse possível identificar tais desigualdades, a saber: (1) completar a $1^{\mathrm{a}}$ série do ensino fundamental; (2) completar a $4^{\mathrm{a}}$ série do 
ensino fundamental; (3) completar o ensino fundamental; (4) completar o ensino médio; (5) completar um ano de universidade; e (6) completar a universidade. Dessa forma, foi possível identificar que apesar de se constatar a existência de desigualdade nas chances de transição social tanto em função da classe social quanto em função da etnia de origem, pontua-se que a desigualdade de classe diminui conforme vão se sucedendo as transições ascendentes, ocorrendo o inverso com a desigualdade racial intensificando-se quanto maior a ascendência escolar. Diante desse contexto, há necessidade de se repensar políticas específicas contra as desigualdades no ensino superior, o que exige indubitavelmente reflexões sobre etnia e mestiçagem.

\subsubsection{Definição étnica versus mestiçagem}

Outras reflexões sobre cotas partem dos princípios de que se o brasileiro é visto etnicamente como "miscigenado", como definir quem é negro no Brasil? A polêmica gerada pelas cotas para determinadas etnias chama atenção para a volta da taxonomia bipolar (FRY; MAGGIE, 2004) entre brancos e negros, ou seja, essa medida contribui para a volta do pensamento de divisão do ser humano em raças, trazendo a questão racial para que seja re-discutida. É evidente que medidas que diferenciam grupos sociais dentro de uma democracia causam polêmicas, mas mudar a realidade exige enfrentamento do problema e do conflito em busca do consenso possível.

No norte dessa questão, outro aspecto ressaltado sobre a repercussão desse tipo de distinção é que pelo fato de chocar-se com os direitos universais regidos pela Constituição Brasileira, tende a gerar conflitos étnico-raciais. No entanto, deve-se reconhecer que o mito da democracia racial no Brasil vem sendo questionado pela constatação óbvia do preconceito racial no país, ou seja, o olhar democrático da não-discriminação está sendo re-avaliado de acordo com a observação da realidade brasileira. Deve-se, portanto, questionar as bases de enfrentamento das divergências étnicas antes que se culpabilizem processos de intervenção pela emergência de conflitos raciais já existentes na 
sociedade.

O Multiculturalismo propõe uma releitura para o problema racial embasado em uma série de dispositivos peculiares de pensamento da contemporaneidade, de modo que no Brasil os motivos para a definição racial seguem peculiaridades nacionais, diferentes dos experimentados por outros países, como por exemplo, os EUA. É importante ressaltar que o modelo norte-americano refere-se a uma situação específica marcada por relações raciais diferentes das vivenciadas no Brasil.

Numa posição dúbia sobre a existência de uma democracia racial e relações harmoniosas no Brasil, recorre-se freqüentemente ao exemplo dos Estados Unidos, citado como cenário negativo daquilo que poderia acontecer em nosso país. (...) No entanto, nesse raciocínio, anacrônico, esquece-se que as políticas de ação afirmativa vieram num momento posterior a esses acontecimentos e com intenção justamente de tentar contorná-los. (MOEHLECKE, 2004, p.77).

Uma questão inicial que deve ser colocada frente a estratégias de "discriminação positiva" seria: por que soa tão politicamente incorreto discriminar? Que valores ou ideologias estariam objetivados no referido conceito? O processo de "discriminar" ou diferenciar faz parte do desenvolvimento humano: só nos desenvolvemos na medida em que nos tornamos capazes de nos diferenciarmos uns dos outros. Mena (2000) ressalta que o ato de reconhecer a diferença é o início do processo de humanização, sendo fundamental para a formação de novos conceitos e identidades. Negar a diferença corresponderia, portanto, a uma estratégia utilizada para manter o equilíbrio intrapsíquico a partir da eliminação da fonte de insegurança, tensão e ansiedade. Em termos mais específicos, as representações de discriminação estão associadas diretamente ao campo representacional do preconceito racial. No entanto, no âmbito das questões étnico-raciais, o uso vulgarizado do conceito de "discriminação" acabou sendo naturalizado de maneira pejorativa como uma desvantagem valorativa dos negros em relação aos brancos. Busca-se desnaturalizar conceitos como o de discriminação esvaziando-se a conotação de valor pejorativo e abrindo-se possibilidades de interpretação. No caso resgata-se o sentido de diferenciar como algo positivo. Desse modo consideram-se as diversidades étnicas de grupos específicos como qualidade que não deve ser 
eliminada pela tendência de massificação do homem sem origem do mundo globalizado. É sob esta perspectiva que se fundamentam os princípios das ações ou políticas diferenciais.

Nesse sentido, de acordo com Munanga (2004b), a elite intelectual brasileira vem reproduzindo, desde o final do século passado, um modelo de racismo universalista. Esse tipo de racismo atua na desconstrução das identidades étnicas e segue na contramão da constituição plural da sociedade, visto que se busca uma padronização sócio-cultural assimilacionista enraizada no modelo eurocêntrico. Tal modelo centra-se na total negação da diferença e na força ideológica do discurso que naturaliza e engrandece a mestiçagem como fruto de equidade entre os povos. No entanto, a compreensão dessa construção simbólico-ideológica exige que sejam retomados também outros vieses que subjazem o uso deste modelo também como estratégia eugenista de embranquecimento da população. Umas das conseqüências mais negativas desse tipo de racismo é o etnocídio, isto é, a destruição da identidade racial e étnica dos povos dominados. Uma característica do modelo norteamericano é a marca genética incorporada pelas políticas de ação afirmativa, ou seja, o critério utilizado para implementação dessas medidas se dá a partir da árvore genealógica. Daí a insurgência de um recorrente erro argumentativo que fora importado por brasileiros: como definir quem é negro no Brasil, visto que possuímos uma árvore genealógica sofisticada em função do fenômeno brasileiro da miscigenação como é o caso da denominação "moreno" como categoria étnico-racial exclusivamente brasileira. O que determina a afrodescendência brasileira são marcas fenotípicas, aspectos visuais facilmente detectados pelos órgãos públicos de segurança nacional, por exemplo, mas fragmentariamente assumidos por uma população pouco consciente das próprias contradições entre o discurso multirracial e as práticas racistas do dia-a-dia. Ora, há que se considerar que no Brasil as medidas de ação afirmativa destinam-se a populações que sofreram e ainda com o preconceito racial. Especificamente sobre as etnias brasileiras, indígena e negra, a historicidade do processo civilizatório deve ser retomada para a compreensão do presente. 
Em se tratando dos indígenas brasileiros, escravizados por estrangeiros na própria terra natal, colonizados e coagidos em suas tradições culturais e espirituais, muitas famílias indígenas suicidaram-se como forma de resistência à dominação imposta pelos europeus. Em outros casos, pela resistência ao trabalho escravo, muitos chefes de família indígena foram assassinados, expondo suas mulheres e filhos às mais diversas formas de violência sexual, física e moral. Isso sem mencionar os massacres desses povos, quer por doenças trazidas pelos europeus (como varicela, escarlatina, varíola, sarampo, gripe e tuberculose), quer por exércitos portugueses e espanhóis (POTIGUARA, 2002). Já os negros africanos surgiram como alternativa de reposição de mão-de-obra escrava nas lavouras de cana de açúcar. Afastados de suas raízes culturais, pela violência com que foram segregados de seu nicho, foram coagidos a deixarem em seu país de origem costumes, crenças, religiosidade e laços familiares. Dessa forma, durante a escravidão, viveram como um povo desacreditado, identificados como animais de tração. Mesmo diante das adversidades - favorecidas pelo cenário colonial das perseguições, açoites e violenta imposição da supremacia européia mesmo após a abolição da escravatura - os povos africanos, a duras penas, tiveram de resgatar as próprias singularidades, criando clandestinamente as ferramentas necessárias para a sua construção enquanto ser humano.

Tais marcas históricas devem ser consideradas e trabalhadas na medida em que ainda hoje, quando se tornou tão arcaico retornarmos a questões como o racismo, é necessária a busca por recursos que auxiliem a compreensão da pluralidade perdida no processo de massificação do homem construído sem o rastro de sua formação e história (GUARNIERI \& MELO-SILVA, 2007, p.76).

Ao se destituir um povo de história, na medida em que suas peculiaridades são desconsideradas, o passado é esquecido e a compreensão do presente torna-se fragmentária e é prejudicada. É nesse sentido que representantes dos movimentos negros e indígenas, no Brasil, contestam a harmonia mestiça em contraposição à óbvia constatação do preconceito construído historicamente contra etnias negras e indígenas. Nesse sentido, a reserva de vagas para negros e 
povos indígenas ao mesmo tempo em que parece estimular animosidades geradas pela definição étnico-racial, traz também a retomada de considerações importantes sobre os prejuízos sociais causados pelo velado preconceito à brasileira e pela baixa representatividade dessas populações na produção de conhecimento em instituições de ensino superior e Centros de pesquisa a elas vinculados.

Atualmente, a polêmica das cotas universitárias vem sendo discutida por diversos segmentos sociais. No entanto, como essas questões são vistas pelos que são diretamente afetados? O que os estudantes que pleiteiam uma vaga na universidade pensam sobre a implantação das cotas? De um modo geral, como se caracterizam os adolescentes que constituirão a amostra do presente estudo? Para que tais questionamentos possam contribuir para o avanço da discussão aqui proposta, faz-se necessário contextualizar o jovem em sua condição peculiar de desenvolvimento caracterizada pela adolescência; seu modo de lidar com as questões de escolha profissional e de compreender o mundo. Em particular, interessa neste estudo, compreender "as adolescências" com fins de refletir sob a perspectiva dos jovens que poderão ser beneficiados ou não, pelas políticas de ação afirmativa para o acesso à carreira universitária. A seguir são abordadas algumas questões relativas à escolha da carreira, na adolescência, e a preparação via cursos pré-vestibulares para a realização do exame de admissão à carreira universitária.

\subsection{Vestibulandos e o Processo de Escolha Profissional}

Sabe-se que a adolescência, em geral, e a da pessoa que aspira à carreira universitária, em particular, marca um momento de transição, de modo que o jovem, em contextos específicos, vai se re-configurando, deixando de lado certezas da vida infantil e engajando-se em novos projetos em busca de recursos que o auxiliem a se reconhecer enquanto adulto. Nesse processo a questão do 
trabalho e o valor dado à escolha profissional se estabelecem enquanto demanda dessa transição, favorecendo um contato maior do adolescente tanto com a realidade no modo de produção capitalista quanto com as peculiaridades de seu mundo interno.

A dor que lhe produz abandonar seu mundo e a consciência de que vão se produzindo mais modificações incontroláveis dentro de si movem o adolescente a efetuar reformas exteriores que lhe assegurem a satisfação de suas necessidades na nova situação em que se encontra frente ao mundo. (ABERASTURY, 1983, p.27).

O momento da escolha profissional é vivenciado com muita angústia pela maioria dos adolescentes os quais passam por mudanças que vão desde alterações no corpo até reestruturações de sua visão de mundo. Assim, a identidade profissional não deve ser entendida como algo definido, mas em termos de um processo no qual estão envolvidos as mesmas dificuldades a que está sujeita a formação da identidade pessoal (BOHOSLAVSKY, 1991). É nessa fase que o jovem que aspira a uma carreira universitária começa a se preocupar com o futuro, buscando formas de atuação no mercado de trabalho que de alguma forma satisfaçam suas necessidades conscientes ou inconscientes.

Ao buscar uma forma de ocupação, o jovem busca também formas de conseguir sua independência e autonomia para se estabelecer enquanto adulto no mundo do trabalho. Para estar apto a "escolher", ou seja, tomar uma decisão relativa à carreira acadêmica o adolescente deve buscar informações que satisfaçam suas dúvidas e atendam suas necessidades. É necessário buscar informação sobre as carreiras que se relacionam com os interesses e as habilidades do jovem, sua condição educacional e socioeconômica e ao mesmo tempo com as expectativas e possibilidades do mercado de trabalho.

Diante das constantes modificações no mundo do trabalho e diante da proposição de formas alternativas de acesso ao ensino superior o papel da orientação profissional se coloca como ajuda especializada dentro de um determinado contexto que deve abarcar não apenas questões individuais e subjetivas do processo - questões ligadas ao autoconhecimento, interesses, aptidões, habilidades e competências - mas também deve atentar para variáveis externas que muitas vezes dificultam ou até 
inviabilizam a tomada de decisão - determinantes socioeconômico e histórico-culturais, contextos ideológicos, informações sobre as profissões e sobre o funcionamento dos meios de acesso à universidade e do mundo do trabalho - pois adquirem um papel pedagógico para o adolescente em suas escolhas futuras. É nesse sentido que o acompanhamento das carreiras, profissões e mercado de trabalho, o conhecimento sobre conteúdo dos vestibulares e a sistematização de estudo e, sobre a criação de cursos alternativos, entre outros assuntos, deve acompanhar o amadurecimento do jovem para a escolha de carreira.

Desse modo, espera-se que jovens engajados na conquista por uma vaga no ensino superior devam realizar um acompanhamento bastante cuidadoso nos meios de informação levando em conta a atualização e construção do conhecimento sobre as possibilidades de acesso à universidade. Para tal é preciso preparar-se para o vestibular, durante e, ou após o ensino médio que, por sua vez, deveria capacitar o estudante para o ingresso na universidade. Deflagra-se uma crise geral do ensino médio brasileiro que deveria por si só, de acordo com a LDB (1996), possibilitar o prosseguimento nos estudos, preparando seus egressos para que sejam capazes de se adaptarem às condições de ocupação ou aperfeiçoamento posteriores. Ao mencionar a preparação, no contexto brasileiro, entram em pauta os cursos preparatórios para o vestibular.

\subsubsection{Os Cursos Pré-Vestibulares}

Os exames vestibulares são hoje o grande marco da passagem para o mundo acadêmico universitário. "O fenômeno dos vestibulares" é um dos mais importantes rituais de passagem que marca o fim da adolescência e introduz parte da juventude nos espaços privilegiados da universidade (WHITAKER \& ONOFRE, 2006). Os rigorosos processos dessa seleção criaram uma demanda crescente por cursos pré-vestibulares (os chamados cursinhos), os quais têm finalidade de preparar os 
candidatos para êxito nos exames. Dessa forma, dadas as condições não padronizadas para a apresentação dos conteúdos direcionados para a prova do vestibular, os estudantes interessados em ingressar em uma carreira universitária recorrem à complementação nos estudos nesses cursos. Tradicionalmente são cursos ministrados em instituições particulares, os quais condensam o conteúdo programático dos níveis de ensinos anteriores, podendo ter duração de um ano (extensivo) ou seis meses (semi-extensivo). No entanto, há também os chamados cursinhos alternativos que correspondem a instituições de cunho filantrópico que tem como objetivo preparar estudantes em situação de desvantagem educacional e socioeconômica para a realização de exames vestibulares. Alguns desses cursinhos denominados comunitários ou populares visam tanto o treinamento para o domínio dos conteúdos quanto à formação humana e crítica dos estudantes discutindo questões gerais dos valores sócio-culturais e éticos da sociedade brasileira, perpassando desde temas relacionados ao exercício da cidadania até uma apropriação crítica do fazer científico e suas aplicações.

Considerando os cursinhos em geral como espaço já institucionalizado entre o ensino médio e o superior que corresponde ao preparo complementar dos candidatos às carreiras universitárias, poder-se-ia, então, afirmar que as chances de sucesso são maiores para os estudantes que passaram por essa preparação pré-vestibular? Um fenômeno associado à transição do Ensino Médio para Superior denominado "efeito cursinho" por Whitaker e Fiamengue (1989), identificou influência positiva dos cursos preparatórios sobre os desempenhos no vestibular tanto de estudantes da rede pública como da rede privada. No entanto, apesar de existir uma relação diretamente proporcional entre o "efeito cursinho", termo cunhado por Whitaker, sobre a elitização de determinados cursos tidos como de maior prestígio, investigações mais recentes desenvolvidas pelas referidas autoras apontaram para a constatação de ambigüidades geradas pelo efeito.

Se para ingressar na carreira universitária o "cursinho" tem sido necessário para muitos candidatos pode-se pressupor que nos referidos espaços encontrar-se-ão estudantes que decididamente aspiram à universidade. Assim sendo, cumpre questionar como a reserva de vagas na 
universidade é percebida pelo grupo de agentes sociais representados por esses aspirantes à universidade? Na opinião desses jovens quais seriam as repercussões das políticas de cotas a curto, médio e longo prazo? Há implicações dessas medidas sobre as expectativas profissionais desses adolescentes? Nesse sentido, investigar a opinião de vestibulandos de cursos tradicionais e comunitários sobre o vestibular, em suas facetas social, racial e meritocrática é relevante para o conhecimento das perspectivas dos principais interessados na questão, tanto daqueles que julgam que serão "beneficiados" quanto dos que julgam que poderão ser "prejudicados". Assim, espera-se com este estudo contribuir com a produção do conhecimento nas áreas da Psicologia e da Educação, em especial da Psicologia Social, Educacional e da Orientação Profissional e de Carreira.

\section{Objetivo}

O objetivo geral desta pesquisa consiste em investigar as opiniões de estudantes em situação de vestibular sobre as medidas de ação afirmativa no ensino superior, o sistema de reserva de vagas para grupos específicos da população. Com relação aos objetivos específicos pretende-se trazer contribuições para o debate sobre cotas universitárias no momento de implantação, que é recente no Brasil, fornecendo dados atuais diante de uma amostragem de estudantes que recebe diretamente a influência dessas medidas governamentais.

\section{Método}

\subsection{Universo de Estudo}

No percurso metodológico duas etapas antecederam a definição da amostra e a coleta dos 
dados propriamente dita. Trata-se da busca de informação em meios de comunicação de massa, via internet, sobre o universo dos vestibulandos; e da participação no Fórum Regional de Cursinhos prévestibular, fundamentais para a imersão no universo da população objeto de estudo. Considerando que essa aproximação constituiu-se em uma etapa inicial do percurso metodológico, optou-se por inseri-la no método.

\subsubsection{Meios de comunicação de massa e internet}

Objetivando aproximação ao objeto de estudo, em um primeiro momento buscou-se adentrar o universo dos vestibulandos por meio de buscas na mídia impressa, em fóruns de discussão e sites de relacionamento via internet, e em um evento que aproximou a pesquisadora do universo dos cursinhos comunitários.

Para que fosse possível obter uma visão a priori a respeito dos debates mais recentes sobre as cotas entre os adolescentes, realizou-se uma busca inicial nos meios informativos de maior circulação como revistas e jornais comerciais (Caros Amigos, Veja, Estadão, Folha de São Paulo), consultas pela internet em salas de bate-papo selecionadas por idade, dando-se preferência para as que possuíssem mais integrantes. Os resultados desse levantamento inicial relativo às opiniões sobre o tema das cotas universitárias mostraram posicionamentos ou "contra" ou "a favor" à referida medida de ação afirmativa, sinalizando as visões antagônicas como apontado na revisão da literatura. Observaram-se as opiniões e os argumentos de sustentação de cada posição defendida pelos participantes. Foi possível, através das salas de bate-papo na internet - chats - interagir com os internautas colhendo informações específicas sobre as cotas universitárias em tempo real. De acordo com o que foi observado, parece não haver clareza, entre os internautas, sobre o programa de cotas universitárias. Há muitas dúvidas sobre definições básicas, sendo que o teor emocional parece caracterizar opiniões incipientes envolvendo etnia e pertença social, de modo que muitas das conversas terminavam com xingamentos, palavras de baixo calão e intolerância entre as partes discordantes. Muitos dos jovens 
apesar de admitirem não possuir conhecimento sobre o assunto, já se posicionavam sobre as mesmas, de modo que as crenças individuais e o julgamento - favorável ou contrário - precediam o próprio significado ou definição que eles possuíam sobre cotas. Observou-se a necessidade de se realizar reflexões sobre o significado da discriminação positiva.

A maioria dos opinantes recusou-se a aceitar pontos de vista divergentes dos seus, estando engajados em fundamentar a própria argumentação. Entre os que apóiam a medida pôde-se perceber ambivalência quando questionados sobre os critérios étnicos utilizados na determinação de quem deve ou não ser beneficiário do programa. Já entre os que não concordam com a medida, houve ambivalência nas respostas quando questionados sobre existência desigual de oportunidades entre diferentes grupos étnicos e socioeconômicos no Brasil. Foram poucos os que se justificaram tentando compreender argumentos divergentes ao seu ponto de vista. Foi possível distinguir na atitude dos jovens relativas às políticas de cotas uma tendência a discórdias observadas nas conversações, sendo as mesmas norteadas pela dificuldade de compreender e aceitar opiniões divergentes. Pode-se inferir que os participantes dos chats funcionam em termos de posição maniqueísta, a favor ou contra. É também importante atentar, além da transmissão e veiculação das informações, em que medida fatores de ordem emocional influenciam a apropriação e o posicionamento diante de uma medida como essa, que contrapõe o mito versus a realidade das relações de poder na democracia racial brasileira.

Independentemente da postura que se assuma frente às cotas, deve-se ressaltar a importância da implementação de políticas públicas enquanto resultado de mobilização social e enquanto disparador temático da discussão política acerca de questões raciais no Brasil. De modo geral, o que se espera com a adoção do programa de cotas é que o número de estudantes egressos da rede pública de ensino (em especial alunos de origem afro-brasileira) aumente nas universidades públicas - bem como nos cursos mais concorridos - além de trazer à tona reflexões e consciência crítica diante das políticas de participação e de interesse da população, corroborando as idéias de Araújo e Araújo 
(2003). “(...) O debate situa-se na encruzilhada de duas questões capitais para o país: a organização do ensino público e a redução das desigualdades raciais e sociais. São matérias complicadas que devem ser abertamente discutidas numa sociedade democrática” (ARAÚJO \& ARAÚJO, 2003).

Para tanto, torna-se necessária a realização de estudos e levantamentos acerca de considerações mais específicas sobre o programa de cotas, para que seja verificado de que modo a discussão sobre as cotas vêm sendo realizada; quais os pontos de avanço ou retrocesso do debate sobre a questão, de modo a serem compreendidos em sua complexidade pela população em geral e os jovens em particular. Pelo fato de se tratar de uma implementação legislativa relativamente recente, cuja lei federal ainda se encontra em debate no Congresso Nacional, faz-se necessário acompanhar as repercussões dessas medidas que desencadeiam programas de intervenção governamental nos três níveis, federal, estaduais e municipais. Assim sendo, esse trabalho visa investigar opiniões sobre as cotas universitárias na perspectiva de estudantes em situação de vestibular, ou seja, estudantes interessados em ingressar em uma carreira universitária. Tais estudantes representam o grupo social que poderá ou não ser beneficiado pela implantação das cotas universitárias. Nesse sentido, compreender a perspectiva de vestibulandos, em instituições de duas naturezas -pública ou comunitária - poderá contribuir enquanto subsídios para avanço de reflexões referentes, por exemplo, às influências de medidas como as de cotas universitárias nas expectativas de carreira profissional dos jovens. A fim de alcançar tais objetivos o contato com cursinhos foi necessário, em especial com os comunitários, populares ou alternativos, que precisavam ser identificados e localizados na cidade e região.

\subsubsection{O Fórum Regional de cursinhos alternativos}

A fim de aproximar-se dos cursinhos comunitários, compreender a dinâmica e funcionamento de um dos grupos que constituiu a amostra deste estudo a pesquisadora participou de um evento que ocorreu em outubro de 2006, intitulado “III Fórum Regional de Cursinhos Populares” organizado por 
professores e coordenadores de cursos populares e comunitários. O evento foi sediado na cidade de Franca, com a participação de quatro cursinhos de Ribeirão Preto (Centro de Apoio Popular - CAP; Centro de Apoio Popular Estudantil - CAPE; Núcleo de Apoio ao Vestibulando - NAV; Cursinho Conexão), um de Franca (Serviço de Extensão Universitária - SEU / Unesp), um de Passos (Educação e Cidadania de Afrodescendentes e Carentes - EDUCAFRO) e um de Jaboticabal (Ativo / USP). Tal evento trouxe contribuições significativas inclusive para a definiç̧ão dos chamados cursos pré-vestibulares comunitários ou alternativos. O objetivo do Fórum foi proporcionar um espaço para reflexão sobre o papel dos cursinhos na formação dos estudantes, no sucesso dos vestibulares públicos, além de problematizar conseqüências negativas geradas pelo exame vestibular contextualizado nos moldes da Educação nacional atual. Foram realizadas palestras com os seguintes temas: "Conjuntura Nacional: a educação e o vestibular em debate", "A missão dos cursinhos populares de Ribeirão Preto e região" e "A experiência de quem fez cursinho popular e conseguiu aprovação: depoimento de ex-alunos”.

De acordo com tal conteúdo proposto e segundo depoimentos de alunos e professores colhidos durante o Fórum, observou-se que eventos dessa natureza visam contribuir para o estabelecimento de uma atualização de identidade dos estudantes nessa modalidade de cursinho, interessada em se diferenciar dos demais por seu engajamento em questões sociais, políticas e críticas, sendo voltadas para um público distinto tanto economicamente quanto culturalmente, com demandas que destoam dos cursinhos tradicionalmente particulares, com perfil de alunos diferenciados em termos educacionais, culturais e socioeconômicos. Observou-se, assim, uma preocupação latente com a definição de uma identidade compartilhada por professores e alunos, sendo esse o tema central do Fórum.

A partir desse encontro, definiram-se critérios para a constituição dos grupos de participantes deste estudo, que diferenciassem os cursos comunitários ou populares dos particulares ou tradicionais, os quais serão expostos a seguir. Em termos gerais, de acordo com o relato dos coordenadores 
entrevistados, designam-se populares ou comunitários os cursos pré-vestibulares que não tenham fins lucrativos e se destinem a ser uma alternativa para estudantes com dificuldades financeiras para custearem um curso particular, daí a denominação "alternativos”.

Nesses cursinhos, os professores são, em grande maioria, estudantes de universidades públicas, às quais - não raro - são sedes dos mesmos. Normalmente, há um preço estipulado para a matrícula, inscrição e mensalidade, que varia de $\mathrm{R} \$ 10,00$ a $\mathrm{R} \$ 25,00$; valor destinado à compra de material - giz, papel e xérox - sendo o pagamento facultado aos vestibulandos, de acordo com suas possibilidades financeiras. No entanto há que se acrescentar que há cursinhos que cobram mensalidades mais expressivas (cerca de R\$ 150,00 - exemplo citado por um coordenador de um cursinho popular em Franca) e que ainda assim se autodenominam comunitários. Constata-se assim a existência de uma polêmica essencial para as definições cursinhos "populares", "comunitários", "públicos" ou "alternativos", havendo ainda bastante controvérsia sobre o assunto. Para fins do

presente estudo, serão utilizadas expressões como: comunitários, populares e, ou alternativos, para referir aos participantes de um dos grupos que constitui a amostra deste estudo.

\subsection{Participantes}

Foram considerados elegíveis para participar deste estudo alunos interessados no ingresso em uma carreira universitária, podendo ter passado ou não pela experiência do vestibular. Participaram desta etapa 107 vestibulandos matriculados em cursos pré-vestibulares de duas cidades do interior do Estado de São Paulo (Ribeirão Preto e São Carlos), distribuídos em dois subgrupos: um de natureza administrativa denominada comunitária, identificados como Grupo A (GA) e outro de administração particular, identificados como Grupo B (GB). 
Como a proposta deste estudo envolve a comparação entre os sexos e entre a procedência do cursinho, houve a necessidade de reajustar a amostra em ambos os casos. No primeiro, buscou-se alcançar a meta de equilíbrio no número de sujeitos nos subgrupos por procedência escolar e por sexo, como mostra a Tabela 5. Considerando-se a natureza voluntária da participação, observou-se na prática uma participação feminina mais expressiva. A amostra total foi composta por $60,8 \%$ de mulheres, e em cada grupo essa porcentagem corresponde respectivamente a 60,4 no GA e 61 no GB. A faixa etária dos participantes variou entre 16 e 28 anos, com média de 17,8 anos de idade no Grupo A e, entre 16 e 24 anos, com média 18,7 anos no grupo B.

Tabela 5 - Distribuição dos participantes dos grupos A e B tendo a procedência dos cursos como variável central.

\begin{tabular}{ccccccc}
\hline & \multicolumn{2}{c}{ Grupo A } & \multicolumn{2}{c}{ Grupo B } & \multicolumn{2}{c}{ TOTAL } \\
\cline { 2 - 7 } & $\mathrm{n}$ & $\%$ & $\mathrm{n}$ & $\%$ & $\mathrm{n}$ & $\%$ \\
\hline Moças & 32 & 60,4 & 33 & 61 & 65 & 60,8 \\
\hline Rapazes & 21 & 39,6 & 21 & 39 & 42 & 39,2 \\
\hline TOTAL & 53 & 100 & 54 & 100 & 107 & 100 \\
\hline
\end{tabular}

\subsection{Instrumentos}

Foram utilizados os seguintes instrumentos: (a) Questionário desenvolvido para fins desse estudo, por Guarnieri e Melo-Silva, intitulado "Mapeamento da Opinião sobre Cotas Universitárias" (COTAS); e (b) Entrevista individual. Ambos serão descritos a seguir.

\subsubsection{Questionário COTAS}

Consiste em um instrumento (Anexo A) elaborado pela pesquisadora e orientadora com base no questionário de Moehlecke (2004), o qual se encontra no Apêndice A. O detalhamento do processo de elaboração do instrumento utilizado neste estudo encontra-se no Apêndice B. 
O Questionário COTAS (Anexo A) divide-se em três partes. A primeira corresponde às informações sócio-demográficas, aos dados do participante e de seus pais ou responsáveis, no que se refere à escolaridade, atividade profissional e autodenominação étnico-racial (questões de número 1 a 11). Ressalta-se aqui a importância da noção de capital cultural segundo Bourdieu (2003) e sua transmissão doméstica para a desigualdade de desempenho escolar de estudantes de diferentes classes sociais.

[...] a transmissão do capital cultural é, sem dúvida, a forma mais dissimulada da transmissão hereditária do capital; por isso, no sistema das estratégias de reprodução, recebe um peso tanto maior quanto mais as formas diretas e visíveis de transmissão tendem a ser mais fortemente censuradas e controladas (p. 76).

Por exemplo, dados sobre a escolarização dos pais e mães sinalizam o tempo de aquisição do capital familiar e as relações com a transmissão do arsenal cultural aos filhos, bem como o papel da família em assegurar tempo liberado da necessidade econômica (aquisição inicial de capital cultural).

A segunda parte (questões de 12 a 19) do instrumento corresponde à opinião propriamente dita dos participantes em termos de conteúdo e objetivos específicos do estudo, e é composta por cinco questões de múltipla escolha $(14,16,17,19)$ e quatro questões em escala Likert de quatro pontos $(12,13,15$ e 18). Com relação aos temas, pode-se dividi-lo em 4 subseções: Vestibular (12a, 12b, 12d, 18e, 18g e 18h), Cotas Universitárias (17, 17.1, 17.2, 18a, 18b, 18c, 18d, 18f e 19), Medidas Governamentais de acesso ao Ensino Superior (13b, 13c, 13d e 15c) e Questão Racial (12c, 15a, 15b, $15 \mathrm{~d}, 15 \mathrm{e}, 15 \mathrm{f}, 15 \mathrm{~g}, 15 \mathrm{~h}, 15 \mathrm{i}$ e 14$)$. Já a terceira parte corresponde a uma questão sobre a avaliação do questionário (questão 20) em escala Likert de cinco pontos e uma questão aberta (referida anteriormente) para exposição de comentários, além de informações pessoais para localização e estabelecimento de contato posterior com os participantes a fim de dar continuidade ao estudo. 


\subsubsection{Entrevista Individual}

A utilização desse instrumento marca a $2^{\mathrm{a}}$ etapa do estudo em que se permitiu aos participantes não apenas expor como também fundamentar seu posicionamento e perspectivas, trazendo questões que lhes eram mais latentes sobre as cotas universitárias e sobre seu contexto. Tratou-se de entrevistas individuais, semi-estruturadas, cujos temas centrais referiam-se à opinião pessoal sobre as cotas e às perspectivas individuais futuras. Outros temas foram abordados na medida em que emergiam em função do conteúdo que era disparador temático. O objetivo dessa etapa foi promover uma investigação mais aprofundada do referencial dos vestibulandos acerca dos temas abordados pelo questionário e trazidos pelo entrevistado, além de abordar as perspectivas futuras dos participantes frente à escolha profissional. De acordo com Bleger (1998) a entrevista constitui-se em uma técnica de investigação científica em Psicologia, com seus próprios procedimentos e regras empíricas, porém não se restringe apenas a ampliar as informações, mas também amplia a interação da prática com o conhecimento científico.

\subsection{Considerações Éticas}

O presente estudo foi submetido ao Comitê de Ética em Pesquisa (CEP) da Faculdade de Filosofia, Ciências e Letras de Ribeirão Preto (FFCLRP) na Universidade de São Paulo (USP), sendo analisado e aprovado. Elaborou-se para fins desse estudo uma Carta de Autorização para as Instituições (Anexo B) que participaram da pesquisa, sendo entregue ao representante do cursinho e apresentada juntamente com uma entrevista breve sobre características e objetivos do cursinho e sobre o perfil dos estudantes. 
O Termo de Consentimento Livre e Esclarecido (Anexo C) teve como finalidade esclarecer aos estudantes no que consistia a sua participação nas duas etapas do estudo. Além disso, explicitouse o objetivo do estudo, o caráter voluntário da participação na pesquisa, a possibilidade de encerramento da participação em qualquer momento e esclareceram-se as condições éticas sobre sigilo e manuseio de tais dados pela pesquisadora. Os termos foram assinados pelos participantes e, nos casos de menores de 18 anos, foram assinados também pelos pais ou responsáveis. A pesquisadora colocou-se à disposição para possíveis esclarecimentos acerca dos temas relacionados à pesquisa. Todos os participantes da primeira etapa foram instruídos sobre a possibilidade de serem convidados para a realização da entrevista em etapa posterior.

\subsection{Procedimento de coleta de dados}

A coleta dos dados foi realizada em duas etapas. A primeira consistiu na aplicação coletiva do questionário intitulado COTAS nos próprios cursinhos ou mediante entrega do material em mãos aos vestibulandos para serem respondidos em sua residência, conforme instrução do coordenador de um dos cursinhos. Foram preparadas e entregues 230 cópias do questionário, dos quais 139 foram preenchidos e devolvidos para a pesquisadora. A segunda etapa correspondeu à realização de entrevistas individuais semi-estruturadas em situação face a face com seis participantes da etapa anterior. Os procedimentos específicos de cada etapa serão descritos detalhadamente a seguir.

\subsubsection{Etapa 1}

Foram contatados a priori seis cursos pré-vestibulares particulares de Ribeirão Preto: Colégio Objetivo, Anglo Carlos Chagas, Colégio Albert Einstein, Colégio Vianna, Liceu Albert Sabin, e Colégio e Curso Oswaldo Cruz (COC), e quatro comunitários (Centro de Apoio Pedagógico 
Estudantil - CAPE, Programa de Ensino Interdisciplinar Comunitário - PEIC, Escola Estadual de Ensino Médio “Otoniel Mota” e Cursinho Pré-vestibular da Universidade Federal de São Carlos UFSCar). No entanto confirmaram a participação no presente estudo dois cursinhos particulares de pequeno e médio porte: Colégio Vianna e Liceu Albert Sabin e três comunitários de pequeno, médio e grande porte: PEIC, Colégio Otoniel Mota e Cursinho Pré-vestibular da UFSCar. Quatro deles localizam-se na cidade de Ribeirão Preto e um em São Carlos.

O Cursinho Pré-vestibular da UFSCar foi contatado em função do tempo de funcionamento e consistência institucional em termos estruturais, administrativos e pedagógicos. A título de esclarecimento, o que ganhou atenção em especial foram as chamadas "turmas de dois anos", desenvolvido, especificamente, para estudantes que estão afastados a muito tempo dos estudos e, ou por aqueles com graves dificuldades em disciplinas básicas. Nessas turmas, o conteúdo do $1^{\circ}$ ano consiste nos reforço em Português e Matemática (disciplinas básicas para a compreensão de todas as demais); na abordagem de paradigmas científicos contextualizados de acordo com situações trazidas do cotidiano dos alunos; e na preocupação em conscientizar os alunos sobre problemas sociais, sobre o exame vestibular, a universidade e o mercado de trabalho em geral. Já o $2^{\circ}$ ano direciona-se ao treino para os exames, próprio da idéia de curso preparatório para o vestibular.

O contato com as instituições de ensino participantes foi realizado inicialmente por telefone, momento em que as escolas eram informadas acerca dos objetivos da pesquisa e decidia se participaria ou não. Quando da aceitação em participar da pesquisa, era agendado um horário para apresentação dos seguintes documentos: instrumento de coleta, termos de consentimento - os quais foram entregues aos estudantes - e uma autorização a ser assinada pelo diretor ou coordenador responsável pelo cursinho, para incorporar a documentação submetida ao Comitê de Ética em Pesquisa da Faculdade de Filosofia,Ciências e Letras de Ribeirão Preto (FFCLRP/USP). Com esse mesmo responsável era realizada uma entrevista com a finalidade de esclarecer possíveis dúvidas acerca da pesquisa e de conhecer um pouco mais sobre a Escola, sua estrutura e funcionamento, bem 
como dados gerais sobre os alunos. Durante a entrevista foram acordadas estratégias para a aplicação e recolha do instrumento, negociadas entre a pesquisadora e os coordenadores de cada curso preparatório em função do objetivo da pesquisa e da disposição estrutural e de funcionamento das instituições de ensino.

Nos cursinhos populares contatados para os fins do presente estudo, o acesso da pesquisadora aos estudantes foi facilitado pela gestão mais descentralizada de tais cursinhos. No primeiro cursinho visitado - Escola Estadual de Ensino Médio Professor Otoniel Mota -, o coordenador sugeriu reservar uma sala que estava inativa para aplicação coletiva, de modo que ele mesmo encaminharia estudantes que aceitassem participar voluntariamente da pesquisa para o local. Foi a estratégia mais vantajosa para a pesquisadora, pois teve a totalidade dos questionários preenchidos e em grande quantidade. Tal aplicação ocorreu em uma manhã e uma tarde. Em outro cursinho dessa natureza, o PEIC, a aplicação do instrumento foi realizada em alunos que estavam fora da sala de aula e em intervalos. Quando os coordenadores foram interrogados sobre qual seria o objetivo principal do cursinho, responderam que pretendiam ir além do objetivo de preparo e treino para os vestibulares, acrescentando-se a função formadora e crítica aos vestibulandos desses cursinhos. Reconheceram que o objetivo final continua sendo a busca por sucesso no vestibular, o que significa resultado, mas acrescentaram que além do treino para o vestibular, uma das grandes preocupações dos cursinhos populares seria com a formação de uma consciência política, social e cidadã dos vestibulandos, sendo que em muitos casos o despreparo dos alunos carentes ultrapassa a barreira do conteúdo programático do ensino médio deficiente, abarcando a falta de informações sobre o mercado de trabalho e, em alguns casos, total desconhecimento sobre a gratuidade das universidades públicas, tampouco sobre as alternativas de apoio ao ingressante dentro do espaço dessas Instituições, como, por exemplo, as bolsas: alimentação, moradia, trabalho.

Nos cursinhos particulares, as estratégias de intervenção da pesquisadora junto aos estudantes foram mais restritivas. Nos três casos, a entrega e a recolha dos questionários ficou sob 
responsabilidade dos coordenadores. De acordo com relato dos coordenadores, houve consenso de que o objetivo do cursinho é preparar e treinar aspirantes à universidade para ingresso nos grandes vestibulares, ou seja, nas carreiras de prestígio. Para fins do presente estudo, serão utilizadas expressões como: comunitários, populares e, ou alternativos, para referir aos participantes do grupo A, como mencionado anteriormente. Enquanto que os participantes do grupo B serão designados como provenientes de cursinhos particulares, privados ou tradicionais.

\subsubsection{Etapa 2}

$\mathrm{Na}$ segunda etapa, foram realizadas entrevistas individuais com seis participantes, sendo três do Grupo A e três pertencentes ao Grupo B. Além da disponibilidade do estudante para participar da entrevista, outro critério inicial utilizado para seleção dos entrevistados foi referente ao preenchimento da sessão "comentários", ao final do questionário. Nessa sessão havia sugestões e questionamentos pertinentes ao questionário e ao tema proposto pelo mesmo (cotas universitárias, vestibular, etc). Tal critério estabeleceu-se pelo fato de sugerir interesse dos participantes em discorrer um pouco mais sobre tema. Os convites para a entrevista deram-se mediante contato telefônico, no qual a pesquisadora localizava o jovem, verificava se havia interesse e disponibilidade do mesmo em participar da entrevista. Em caso afirmativo, estabelecia-se um local, data e hora que correspondessem às possibilidades da dupla (entrevistador-entrevistado). Dos convites realizados, sete foram descartados, pois os participantes recusaram-se a dar entrevista alegando indisponibilidade de tempo $(n=3)$; falta de interesse sobre o assunto $(n=1)$; ou não alegaram qualquer motivo $(n=3)$. Ao final foram entrevistados efetivamente seis participantes, sendo três do Grupo A e os outros três do Grupo B.

As entrevistas duraram em média 20 minutos, sendo que a mais longa teve duração de 40 minutos (Bruno) e mais curta, 15 (Bianca). As entrevistas foram iniciadas e gravadas com o consentimento dos entrevistados. O eixo da entrevista foi a opinião dos participantes sobre as cotas 
universitárias. Buscou-se investigar quais as temáticas mais se destacavam nas falas dos entrevistados (conteúdos afetivos, cognitivos e ideológicos). Outros temas pertinentes, como, por exemplo, o vestibular e o preconceito racial, ao serem abordados pelos entrevistados eram também explorados pela pesquisadora durante a entrevista.

\subsection{Procedimento de análise dos dados}

\subsubsection{Recursos estatísticos e quantificação}

Os dados obtidos por meio do Questionário foram tratados quantitativamente com base nos seguintes recursos estatísticos: análises univariadas e bivariadas; teste de significância; teste de QuiQuadrado e o Teste exato de Fisher. A utilização da análise univariada dá-se a partir de fins descritivos, em que cada variável é examinada exclusivamente. Já o uso da análise bivariada tem objetivo explicativo por meio do qual se busca conhecer a relação que existe entre valores de uma variável dependente (opiniões dos participantes sobre as temáticas do questionário) e de uma independente (sexo e idade), em termos de probabilidade. O teste de significância expressa relação de probabilidade e foi adotado como nível de significância $\mathrm{p} \leq 0,05$. De acordo com Babbie (2001 apud MOEHLECKE, 2004).

[...] três níveis de significância são usados freqüentemente em relatórios de pesquisa: 0,05, 0,01 e 0,001. Esses números significam, respectivamente, que as probabilidades de se obter a associação medida como resultado de erro de amostragem são 5/100, 1/100 e 1/1000. (p. 27)

O teste de Qui-Quadrado foi utilizado neste estudo por corresponder a um teste de significância que mede a probabilidade de as diferenças encontradas nos grupos amostrais estarem ou não ocorrendo ao acaso. Se a probabilidade for alta conclui-se que não há diferenças estatisticamente significativas. Se a probabilidade for baixa (no caso, menor que 5\%) conclui-se que há diferença 
estatisticamente significativa determinada pela variável em questão. O Teste exato de Fisher foi utilizado em situações que limitam a utilização do Qui-Quadrado, ou seja, quando os valores esperados nas células da tabela são inferiores a cinco.

\subsubsection{Análise Qualitativa}

As entrevistas foram tratadas qualitativamente, a partir da Análise de Conteúdo de Bardin (1977), que consiste em "um conjunto de técnicas de análise das comunicações, que utiliza procedimentos sistemáticos e objetivos de descrição do conteúdo das mensagens, indicadores (quantitativos ou não) que permitam a inferência de conhecimentos relativos às condições de produção/recepção (variáveis inferidas) destas mensagens" (BARDIN, 1977, p. 42). Parte-se da leitura per se do material, sentidos que se encontram "em segundo plano" (p. 41) são realçados através da inferência e da interpretação. Estudos dessa natureza desenvolvem-se em torno de três pólos: (a) a pré-análise; (b) a exploração do material; (c) o tratamento dos resultados - a inferência e a interpretação. A pré-análise tem por finalidade de estabelecer contato com o material a partir da leitura flutuante. A exploração do material consistiu em hipóteses provisórias formuladas a fim de construir categorias de análise, temas centrais associados a alguns critérios estruturais dos estudos. $\mathrm{Na}$ etapa final, a partir da inferência e interpretação, os dados são organizados em unidades de análise centrais, que neste caso corresponderam a dois eixos centrais das entrevistas: (1) Cotas Universitárias: Prós e Contras; e (2) Trajetórias e Perspectivas.

\subsubsection{Escopo Teórico-Metodológico}

Os dados quantitativos e qualitativos foram tratadas a partir de abordagens qualitativas de apreensão dos fenômenos observados. As principais noções norteadoras das análises que permitiu a leitura das problemáticas apresentadas foram embasadas na teoria sócio-cognitiva de desenvolvimento de carreira e no enfoque dialético da teoria das representações sociais, como 
recursos teóricos férteis e complementares para tratar das questões suscitadas pelas informações obtidas.

Parte-se do princípio de que a Psicologia, enquanto área do saber humano voltado para as interações indivíduo-sociedade, deve se inserir em um contexto de compromisso ético-político e social diante das ações que se refletem e são refletidas pelo grau e qualidade dessas interações recíprocas. Assim, “compreender a relação sujeito-objeto é compreender como o ser humano se relaciona com as coisas, com a natureza, com a vida" (PIRES, 1997). Nesse contexto, a perspectiva de homem adotada pelo presente, assenta-se sobre a definição utilizada pelos estudiosos da Teoria da Complexidade, Morin e Moigne (2000), para ilustrar uma perspectiva engajada no reconhecimento das relações dialéticas que constituem o ser humano - e são constituídas por ele - em interação contínua consigo mesmo, com os outros e com o meio em que vive.

O ser humano é um ser racional e irracional, capaz de medida e desmedida; sujeito de afetividade intensa e instável. Sorri, ri, chora, mas sabe também conhecer com objetividade; é sério e calculista, mas também ansioso, angustiado, gozador, ébrio, extático; é um ser de violência e de ternura, de amor e de ódio; é um ser invadido pelo imaginário e pode reconhecer o real, que é consciente da morte, mas que não pode crer nela; que acredita no mito na magia, mas também na ciência e na filosofia; que é possuído pelos deuses e pelas idéias, mas que duvida dos deuses e critica as idéias; nutre-se dos conhecimentos comprovados, mas também de ilusões e de quimeras. (p.116).

As temáticas humanas evocadas pela política de Ação Afirmativa representadas aqui pelas “cotas universitárias” são muito abrangentes, carregadas de marcas históricas e ideológicas, além de contradições inerentes ao entendimento das interações ético-políticas e étnico-raciais na construção do saber partilhado pela população em geral. Pelo nível de sofisticação e complexidade dos fenômenos humanos a que se remetem, tais questões serão tratadas considerando-se contextos e conteúdos construídos socialmente e os processos dialéticos subjacentes.

A linha teórica seguida aproxima-se da linha sugerida por Minayo (1992) para denominar a metodologia de pesquisa qualitativa, corrente preocupada não apenas em quantificar o fenômeno observado, mas que busca "explicar os meandros das relações sociais consideradas essência e 
resultado da atividade humana criadora, afetiva e racional que pode ser aprendida no cotidiano, da vivência e da explicação do senso comum” (p.11). Outro apontamento da referida autora destaca a dialética marxista como abordagem que supera linhas teóricas positivistas e compreensivistas pelo fato de abarcar além do sistema de relações que constroem o conhecimento externo ao indivíduo, considerando também o significado das representações sociais resultantes das relações objetivas dos atores sociais. Ressalta-se ainda que diante da problemática da oposição aparente entre as abordagens quantitativa e qualitativa, a perspectiva dialética atua sobre a dissolução dessa dicotomia, assumindo que ambas são inseparáveis e complementares. Nesse sentido, convém esclarecer que para a realização do presente estudo contou-se com a colaboração de ambas as abordagens, em duas etapas: uma quantitativa - utilizada para fornecer dados descritivos do grupo de atores sociais que participaram da pesquisa em um determinado contexto - e outra qualitativa - utilizada para aprofundar questões latentes identificadas coletivamente pela etapa anterior, ou seja, busca-se "aprofundar aspectos da realidade brasileira que os indicadores numéricos apontassem como cruciais" (MINAYO, 1992).

Desse modo, serão apresentadas duas teorias selecionadas para dar leitura aos dados do presente. Trata-se da Teoria Sócio-Cognitiva da Carreira (TSCC) e a Teoria das Representações Sociais (TRS), que se complementam e fornecem um enfoque mais integrado com relação aos objetos desse estudo. Enquanto a primeira teoria orienta-se pela condição dos participantes em processo de escolha profissional, com base no Modelo de Escolha de Carreira de Lent, Hackett e Brown (1994), a segunda teoria permite um olhar dialético sobre questões étnico-raciais, culturais e ideológicas que compõem o universo representacional dos estudantes. Ambas são descritas a seguir. 


\subsubsection{Teoria Sócio-Cognitiva de Desenvolvimento de Carreira}

Tendo em vista que este estudo focaliza a perspectiva de estudantes em situação de vestibular, e que em tal contexto variáveis relativas ao desempenho escolar estão em pauta, os construtos desenvolvidos pela Teoria Social-Cognitiva de Carreira (Social Cognitive Career Theory - SCCT) sobre o conceito de eficácia pessoal foram considerados úteis para iluminar as reflexões sobre os dados. O desempenho escolar, tanto para aprovação no exame vestibular quanto para o sucesso na carreira acadêmica, remete à idéia de auto-eficácia, às expectativas de resultados e aos objetivos que se busca atingir.

Vieira e Coimbra (2006) delinearam um interessante estudo sobre a transição da escola para o mundo do trabalho e seus desdobramentos, tomando como referencial o modelo sócio-cognitivo de desenvolvimento vocacional, que traz outra perspectiva para a compreensão do universo do jovem que se candidata ao ensino superior. A perspectiva sócio-cognitiva centra-se na interação sistêmica entre pessoa, contexto e comportamento (reciprocidade triádica). A compreensão sugerida por esse tipo de abordagem traz considerações acerca da compreensão da dinâmica das variáveis pessoais na percepção do mundo externo (recursos disponíveis, possibilidades) como algo positivo ou negativo ao indivíduo. Como afirmam Vieira e Coimbra (2006), "tal perspectiva não minimiza a importância das características objectivas do contexto, mas chama a atenção para o papel activo do indivíduo enquanto intérprete do seu contexto, isto é, a importância incontornável do significado pessoalmente construído" (p.37), ou seja, subjetivo que se traduz na prática. Assim, as variáveis pessoais ou "variáveis sócio-cognitivas auto-referentes", correspondem: à auto-eficácia, às expectativas de resultados e aos objetivos alcançados.

A auto-eficácia, de acordo com Bandura (1977), citado por Vieira \& Coimbra (2006), corresponde a crenças que o indivíduo possui sobre si mesmo, sobre "sua capacidade para executar cursos de acção requeridos para alcançar determinados tipos de desempenhos" (p.30). Já a 
expectativa de resultados é definida por Lent, Hackett e Brown (1999) como as "conseqüências antecipadas frente a esforços comportamentais" (VIEIRA; COIMBRA, 2006, p.34). Por fim, os objetivos correspondem à determinação do sujeito para se entregar a determinada atividade, buscando alcançar sucesso em futuros resultados. Assim, o desenvolvimento vocacional, com base nesse referencial, delineia-se a partir de três aspectos que interagem entre si e o mapeiam: “(a) a formação e elaboração de interesses vocacionais; (b) a selecção das opções vocacionais; (c) a persistência e o desempenho nas actividades educacionais e profissionais" (p.27). São elencadas seis tarefas evolutivas referentes a essa transição: (1) aquisição de crenças de auto-eficácia e expectativas positivas de resultados ajustadas à realidade; (2) desenvolvimento de interesses acadêmicos e profissionais por determinada área; (3) formação/transformação da união entre os interesses e os objetivos; (4) transformar objetivos em ações; (5) desenvolvimento de competências específicas e competências gerais; (6) negociação de barreiras e apoios que afetam o acesso às opções vocacionais pretendidas.

A Teoria Social Cognitiva de Carreira (TSCC) será utilizada neste estudo para compreender as percepções dos estudantes sobre a situação de vestibular. Assim, os conceitos de auto-eficácia e expectativas de resultados são úteis para discussão dos dados. "Os construtos de auto-eficácia e expectativas de resultado são percepções da realidade; como tal essas percepções podem ou não ser realistas" (SWANSON \& FOAUD, 1999, p.126). A TSCC é apropriada para discutir os dados obtidos porque ela "focaliza nas construções pessoais que as pessoas colocam nos eventos relacionados à tomada de decisão de carreira" (SWANSON \& FOAUD, 1999, p.125). Essas decisões são fundamentadas nos inputs pessoais (predisposições, sexo, raça/etnia, estado de saúde / incapacidade) e no background e fatores contextuais (status sócio-econômico) que juntos influenciam nas experiências de aprendizagem, nesse estudo propiciadas pelas aulas do cursinho, que por sua vez influenciam tanto a auto-eficácia quanto às expectativas de resultados. A auto-eficácia, como mencionado anteriormente, é definida como crenças baseadas nos “julgamentos das pessoas sobre 
suas capacidades para organizar cursos de ações requeridas para atingir tipos de desempenho" (Bandura, 1986, p.391). Neste caso, são crenças de que têm capacidade para entrar na universidade, além de expectativas que a pessoa possui sobre os resultados dos seus comportamentos, ou seja, as crenças pessoais sobre a probabilidade de obter resultado positivo, ou seja, passar no vestibular. Assim, as crenças sobre suas habilidades e as crenças sobre os prováveis resultados levam ao desenvolvimento de interesses, nesse caso, a escolha por alguma carreira universitária. Esses interesses predizem objetivos - passar no vestibular para a carreira escolhida, que por sua vez levam à seleção de atividades como (1) assistir às aulas do cursinho; (2) buscar informações sobre as carreiras; (3) pesquisar informações sobre as inscrições para o vestibular e as diferentes formas de acesso: vestibular, processo seletivo, programas de cotas universitárias, PROUNI, FIES; (4) verificar se há isenção para o vestibular; (5) dialogar coma família sobre o seu projeto de futuro, entre outras ações. Para ao final atingir os objetivos, os resultados do desempenho: ingressar na carreira escolhida e em uma universidade com possibilidades de permanência e conclusão do curso. A Figura 2 mostra o modelo de Lent et al. (1994) com a "predição do desenvolvimento do interesse na Teoria Social Cognitiva de Carreira". 


\subsubsection{Teoria das Representações Sociais}

A Teoria das Representações Sociais (RS) foi introduzida como aporte teórico útil e complementar a TSCC, por focalizar os dilemas e as contradições específicas do universo de estudo investigado. Ou seja, trata-se de uma alternativa teórica que favorece o tratamento das contradições inerentes a questões polêmicas, como as cotas e seus desdobramentos. A sua utilização permite "novas formas de olhar, entender e interpretar os fenômenos sociais, ajudando a compreender, em última análise, por que as pessoas fazem o que fazem" (STREY, 1998, p. 104). Seguem-se algumas considerações sobre a teoria. Epistemologicamente, o surgimento desta resultou da contraposição relativa à "retórica da verdade" (Ibanez apud Spink, 1995). Portanto a teoria das representações insere-se no contexto de mudança de perspectiva das ditas "teorias do conhecimento", ou seja, transição da supervalorização do saber científico - típica do modelo moderno de ciência - para a apropriação do saber popular como conhecimento válido. Ampliou-se a legitimação do senso comum como conhecimento socialmente produzido e motor de transformações sociais. Trata-se do acompanhamento e de observações constantes sobre a dinâmica da formação do senso comum e de suas alterações. Além disso, a importância de tais construções reside na produção de teias de significados para composição de uma realidade criada e ao mesmo tempo criadora nesse processo.

De acordo com a Psicologia clássica, a definição de "representações" indica instâncias intermediárias entre percepção e conceito. De maneira análoga, para Moscovici, a idéia de representação refere-se a um processo que torna o conceito e a percepção, de algum modo, intercambiáveis uma vez que se engendram de maneira recíproca (SPINK,1995). Por se tratar, portanto de uma representação, existe a priori a tentativa de retratar uma dada situação ou posicionamento sob a perspectiva ativa de alguém que se encarrega da missão de representar. É dita "social" por trazer um complexo arsenal composto por regras e valores éticos, políticos, culturais e econômicos intrínsecos à idéia de sociedade e que conferem peculiaridades de um determinado grupo 
de atores sociais.

Em resumo, as RS são estruturas cognitivo-afetivas que devem ser compreendidas a partir do contexto que as engendram e da sua funcionalidade nas interações sociais cotidianas. Emergem como modalidade de conhecimento prático orientado e orientador da compreensão de mundo e para comunicação, parâmetros que devem sempre ser entendidos dialética e contextualmente. A dinamicidade e a historicidade da Teoria da RS são duas de suas características essenciais, ou seja, “as RS estão associadas a práticas culturais, reunindo tanto o peso da história e da tradição, como a flexibilidade da realidade contemporânea delineando as representações sociais como estruturas simbólicas desenhadas tanto pela duração, como pela inovação e metamorfose" (STREY, 1998, p. 119).

A utilização dessa teoria no âmbito da Psicologia Social tem se expandido sobremaneira nas últimas décadas. No entanto, um dos grandes desafios que se coloca aos teóricos afinados com a teoria é a dificuldade de defini-la definitivamente, visto tratar-se de uma construção dinâmica e dialética. O próprio Moscovici recusou-se a fazê-lo. Tecnicamente as RS devem ser investigadas dentro de parâmetros específicos. Deve-se considerar a priori o campo de sua origem e formação. Criamos RS quando nos deparamos com situações em que é preciso tornar familiar algo que nos é estranho. O que nos é familiar pertence ao Universo Consensual (UC), que corresponde ao universo de pensamento das teorias de senso comum, as práticas cotidianas e a produção das RS. Já o nãofamiliar pode encontrar amparo em representações pré-estabelecidas que são forçosamente ajustadas ao que ainda não se conhece ou busca respaldo no Universo Reificado (UR), que consiste em teorizações, abstrações e conceituações científicas. Uma relação que se estabelece entre ambos os universos está no fato de que o não-familiar situa-se e é gerado muitas vezes pelo UR e que deverá ser transmitido ao UC, fornecendo perspectivas de enfrentamento para novas situações, por vezes interferindo sobre as RS.

O processo de formação das representações sociais pode ser de natureza conceptual ou 
figurativa. No primeiro caso, a representação é aplicada a um objeto não-presente de modo a atribuir-lhe sentido, simbolizando-o. Já a natureza figurativa refere-se à tentativa de recuperar o objeto não-presente, figurando-o e tornando-o tangível. No âmbito processual mais detalhado das RS envolvem-se dois processos básicos: Ancoragem e Objetivação. Na ancoragem busca-se classificar o não-familiar em modelos pré-definidos que compõem o nosso arsenal de vivências. É comum que recorramos a juízos de valores quando tentamos adaptar o estranho a um arsenal historicamente composto também por valores. De acordo com Doise (apud PEREIRA, TORRES \& ALMEIDA, 2003), existem 3 tipos de ancoragem: a psicológica, a sociológica e a psicossociológica. A primeira aborda a ancoragem nas atitudes individuais. A análise sociológica identifica o modo como a pertença dos indivíduos a grupos sociais influencia as representações. $\mathrm{Na}$ análise psicossociológica a ancoragem permeia os discursos ideológicos sobre a natureza das relações sociais. Já na Objetivação busca-se a concretização de realidades, ou seja, há tentativas de relacionar um conceito a um símbolo ou imagem, trata-se de uma organização cognitiva comum aos membros de uma população sobre alguns elementos que constituem um sistema de relações sociais.

\section{Resultados e Discussão}

Os resultados e a discussão serão apresentados na seguinte ordem: Informações sóciodemográficas, opiniões dos participantes com relação às cotas universitárias; opinião e comentários dos participantes sobre o questionário. Os resultados das entrevistas estão em andamento. 


\subsection{Informações Sócio-Demográficas}

Como referido no método, as informações sócio-demográficas correspondem aos dados dos participantes e de seus pais e mães, com relação à escolaridade e atividade profissional (questões de número 1 a 11). Tais informações, para fins deste estudo, focalizam: (a) autodenominação étnicoracial dos participantes, (b) experiências educacionais dos participantes, (c) exercício de atividade remunerada, (d), a escolaridade dos pais e das mães, e (e) a ocupação dos pais e das mães.

\subsubsection{Autodenominação étnico-racial dos participantes}

Com relação à autodenominação étnico-racial, a Tabela 6 mostra dados da distribuição nos âmbitos: Nacional (população brasileira), do ensino superior e com relação aos Grupos A e B. Nas composições de GA e GB, observou-se que do total de participantes, 75\% se definem como de cor branca; $19 \%$ de cor parda; $3,7 \%$ de cor preta; e quase $1 \%$ amarelo e, ou indígena. Separadamente apresentam a seguinte caracterização: no Grupo A, 59\% consideram-se brancos; $30 \%$ pardos; $7 \%$ pretos e 1,8\% indígenas; e no Grupo B, $91 \%$ dos participantes se identificam como brancos; 7,4\% como pardos; e 1,8\% como amarelos. Os dados do Censo Demográfico de 2000 revelam que do total da população os brancos representam $53,72 \% ; 38,5 \%$ são pardos, $6,2 \%$ pretos e os índios $0,56 \%$. No entanto, no ensino superior essa distribuição indica uma concentração maior dos autodenominados de cor branca, que chega a $79 \%$, versus $17 \%$ de parda, $2,4 \%$ de preta, $1,3 \%$ de cor amarela e $0,2 \%$ de autodenominados indígenas.

Tabela 6 - Distribuições relativas, em porcentagem, da população brasileira, dos estudantes do ensino superior no Brasil e dos grupos A e B deste estudo, de acordo com as categorias étnico-raciais do Instituto Brasileiro de 
Geografia e Estatística (IBGE).

\begin{tabular}{cccccccc}
\hline & Branco & Pardo & Preto & Amarelo & Indígena & S/D & TOTAL \\
\hline População* & 53,7 & 38,5 & 6,2 & 0,4 & 0,56 & 0,7 & 100 \\
\hline Ensino Superior* & 78,8 & 16,8 & 2,4 & 1,3 & 0,2 & 0,5 & 100 \\
\hline GA & 58,5 & 30,2 & 7,6 & 0 & 1.9 & 1,8 & 100 \\
\hline GB & 90,7 & 7,4 & 0 & 1,85 & 0 & 0,05 & 100 \\
\hline
\end{tabular}

* Fonte: IBGE (2000)

Nota-se que tanto no GA quanto no GB, há prevalência, de adolescentes autodenominados brancos, que ainda não cursaram o ensino superior, o que evidencia que há dificuldade de acesso à universidade para qualquer grupo de jovens. Comparando-se GA e GB com a composição étnicoracial da população brasileira e a do ensino superior, observa-se que o GA apresenta uma configuração étnico-racial semelhante à composição da população brasileira, na qual a presença de pardos é mais expressiva. Já a composição do GB assemelha-se à do ensino superior, apresentando dados ainda mais visíveis da hegemonia branca, que chega a 90,7\%, enquanto pardos não chegam a 8\%. Desse modo, a baixa porcentagem baixa de estudantes negros e indígenas também nos cursos preparatórios reforça a reprodução da lógica que mantém essas minorias afastadas de níveis superiores de ensino.

\subsubsection{Experiências educacionais dos participantes}

A natureza administrativa da escola de procedência dos participantes é vista aqui como um indicador de nível socioeconômico dos participantes. De acordo com a Tabela 7, em relação ao ensino fundamental, nos cursos pré-vestibular alternativos (GA), a grande maioria recebeu formação do ensino público, de modo que $84,5 \%$ dos participantes completaram ou cursaram a maior parte dos estudos em rede pública, enquanto apenas $14 \%$ cursou total ou parcialmente na rede particular. 
Tabela 7 - Distribuição dos participantes de acordo com o a procedência escolar do Ensino Fundamental e do Ensino Médio, com relação ao tipo de cursinho. As categorias consideradas foram: totalmente ou maior parte em rede Pública $(\mathrm{Pu})$, totalmente ou maior parte em rede Privada (Pri) ou metade em cada rede (Pu e Pri).

\begin{tabular}{|c|c|c|c|c|c|c|c|c|c|c|c|c|}
\hline & \multicolumn{6}{|c|}{ Ensino Fundamental } & \multicolumn{6}{|c|}{ Ensino Médio } \\
\hline & \multicolumn{2}{|c|}{$\mathrm{Pu}$} & \multicolumn{2}{|c|}{ Pri } & \multicolumn{2}{|c|}{ Pu e Pri } & \multicolumn{2}{|c|}{$\mathrm{Pu}$} & \multicolumn{2}{|c|}{ Pri } & \multicolumn{2}{|c|}{ Pu e Pri } \\
\hline & $\mathrm{n}$ & $\%$ & $\mathrm{n}$ & $\%$ & $\mathrm{n}$ & $\%$ & $\mathrm{n}$ & $\%$ & $\mathrm{n}$ & $\%$ & $\mathrm{n}$ & $\%$ \\
\hline $\begin{array}{c}\text { GA } \\
(n=53)\end{array}$ & 45 & 85 & 8 & 15 & - & - & 50 & 94 & 2 & 4 & 1 & 2 \\
\hline $\begin{array}{c}\text { GB } \\
(n=54)\end{array}$ & 16 & 30 & 37 & 68 & 1 & 2 & 5 & 9 & 48 & 89 & 1 & 2 \\
\hline
\end{tabular}

Os alunos dos cursinhos particulares (GB) receberam a Educação Fundamental, principalmente, no ensino privado, ainda que uma parcela tenha cursado o ensino público. Assim, $68,5 \%$ de GB completou o ensino fundamental ou a maior parte em escola particular; e 29,6\% cursou totalmente ou a maior parte em escolas da rede pública. Sobre o ensino médio, a tendência anterior foi mais intensificada, uma vez que $95 \%$ do GA $(n=50)$ cursou todo ou a maior parte em escola pública, com apenas 5,7\% $(\mathrm{n}=3)$ cursou em rede particular, integral ou parcialmente. No GB, $91 \%$ $(n=49)$ declarou ter completado totalmente em escola particular; e apenas $9 \%(n=5)$ respondeu ter cursado totalmente na rede pública ou a maior parte em escola pública.

Nos itens 4 e 5, levantam-se dados sobre a experiência anterior em vestibulares e, ou ingresso em algum curso universitário. Ou seja, se o participante já prestou vestibular e se iniciou uma faculdade anteriormente. Além de tal experiência fornecer indícios sobre a proximidade do estudante com o universo acadêmico possui também um papel pedagógico para o adolescente em situação de escolha profissional. Ou seja, a experiência prévia media as representações (crenças positivas, negativas ou idealizadas) desses jovens sobre o universo que pretendem conquistar. No modelo da TSCC proposto por Lente t al. (1994), essa vivência prévia referente ao ensino superior insere-se no eixo das Experiências de Aprendizagem, que influenciam diretamente as crenças de auto-eficácia e as Expectativas de Resultado. Isto porque fornecem aos estudantes dados mais realistas tanto sobre as condições do exame em si (competitividade, concorrência candidato vaga, conteúdos exigidos, etc) quanto sobre o próprio desempenho (controle emocional, dificuldades em determinadas disciplinas, 
pontualidade). Ou seja, estudantes que já prestaram vestibulares tendem a conhecer melhor o desafio do que aqueles que ainda não passaram por essa vivência. Informações nesse âmbito foram levantadas em dois itens do questionário: uma sobre a experiência anterior com relação a exames vestibulares e outra sobre ingresso anterior em alguma universidade. Na primeira, prevalecem no GA os estudantes que ainda não prestaram qualquer exame vestibular $(60 \%)$, sendo que em GB, a grande maioria (93\%) já haviam passado por essa experiência. No entanto, na segunda referente ao ingresso anterior em cursos universitários, houve consenso (95\%) de que não haviam passado ainda por essa experiência, sendo que os que responderam afirmativamente (5\%) eram do GB.

\subsubsection{Exercício de atividade remunerada}

O exercício de atividade remunerada concomitante aos estudos foi enfatizado neste estudo por representar uma variável que influencia no preparo do candidato para atingir êxito nos exames, visto tratar de uma atividade que concorre com o tempo e a disponibilidade de preparação desses jovens. Candidatos a uma vaga no ensino superior que não precisem trabalhar possuem, teoricamente, maior tempo disponível para os estudos. No entanto essa relação não é assim tão linear. De acordo com Whitaker e Fiamengue (2003), embora facilmente seja inferida uma incompatibilidade natural entre estudo e trabalho, o que se pode afirmar com certeza é que o "trabalho dificulta a chegada aos mais altos níveis de escolaridade" (WHITAKER, 2003, p. 92). Ainda assim, ressalta que tal afirmação deve considerar aspectos de cada situação separadamente, já que os resultados, para essa autora, dependem de uma série de outros fatores: tipo de curso pretendido, da concorrência, da região, do talento e dos esforços dos candidatos além do tipo de atividade profissional executada.

Nesse sentido, com relação aos participantes da amostra, apenas uma minoria declarou exercer alguma atividade remunerada, concomitantemente ao cursinho, sendo sete do GA e um do GB. No GA, três se autodeclararam negros, dois pardos e dois brancos, e a remuneração variou de $\mathrm{R} \$ 160,00$ a $\mathrm{R} \$ 702,00$ (Média $=\mathrm{R} \$ 403,28)$, que correspondem a faixas salariais abaixo da média no 
Brasil, inclusive do Salário Mínimo, que podem ser entendidos como indício da condição financeira precária desses jovens e suas famílias. No Grupo B, apenas um vestibulando, que se autodeclarou como branco, informou exercer atividade com remuneração de $\mathrm{R} \$ 300,00$. Verifica-se que em GA e GB o índice de estudantes que dividem o tempo de estudo com atividade remunerada é baixo (7,5\%), o que sugere que os alunos de ambos os grupos possuem, teoricamente, condições de tempo para se dedicarem aos estudos objetivando a preparação para os exames de ingresso na carreira acadêmica. Se poucos precisam trabalhar, possivelmente é porque aspirar ao ingresso em um curso superior já é um privilégio de poucos. Nesse âmbito, entre GA e GB, observa-se desvantagem do primeiro, já que as porcentagens correspondem respectivamente a 13,2\% e 1,8\% de jovens envolvidos em atividades extraclasse.

\subsubsection{Escolaridade dos pais e das mães}

A importância da instrução das mães vem se pronunciando cada vez mais em estudos de diferentes países (WHITAKER, 1989), podendo-se afirmar que se trata de um fator de grande relevância na formação do capital cultural da carreira do estudante, visto que ainda hoje o papel da mulher na sociedade contemporânea é bastante voltado para a educação dos filhos e no acompanhamento da vida escolar deles.

Com relação ao grau de escolarização dos pais e mães (Tabela 8), no GA, atingiram o ensino médio $53 \%$ dos pais, $19 \%$ o ensino superior e $17 \%$ o ensino fundamental, sendo que $11,3 \%$ não apresentaram resposta. Ainda no GA, com relação às mães, 67,9\% chegaram até o ensino médio, $22,6 \%$ até o ensino fundamental, 7,6\% alcançaram o ensino superior. 
Tabela 8 - Distribuição, em número absoluto e em porcentagem, do nível de escolaridade dos pais e das mães do Grupo A e do Grupo B.

\begin{tabular}{|c|c|c|c|c|c|c|c|c|}
\hline \multirow{3}{*}{ Nível de Ensino Alcançado } & \multicolumn{4}{|c|}{ GRUPO A } & \multicolumn{4}{|c|}{ GRUPO B } \\
\hline & \multicolumn{2}{|c|}{$\mathrm{PAI}$} & \multicolumn{2}{|c|}{ MÃE } & \multicolumn{2}{|c|}{$\mathrm{PAI}$} & \multicolumn{2}{|c|}{ MÃE } \\
\hline & $\mathrm{n}$ & $\%$ & $\mathrm{n}$ & $\%$ & $\mathrm{~N}$ & $\%$ & $\mathrm{n}$ & $\%$ \\
\hline Sem Resposta & 6 & 11,3 & 1 & 1,9 & 1 & 1,8 & 1 & 1,9 \\
\hline Fundamental & 9 & 17 & 12 & 22,6 & 1 & 1,8 & 0 & 0 \\
\hline Médio & 28 & 53 & 36 & 67,9 & 18 & 33,4 & 16 & 29,6 \\
\hline Superior & 10 & 19 & 4 & 7,6 & 34 & 63 & 37 & 68,5 \\
\hline TOTAL & 53 & 100 & 53 & 100 & 54 & 100 & 54 & 100 \\
\hline
\end{tabular}

Com relação aos pais do GB, 63\% chegaram ao nível do ensino superior, 33,4\% ao ensino médio, sendo que 1,8\% atingiram apenas o ensino fundamental. Entre as mães do GB, 68,5\% alcançaram o ensino superior e $29,6 \%$ chegaram ao ensino médio. Nota-se, portanto, que a maioria dos pais e mães do GA atingiu o ensino médio (53\% e 67,9\%, respectivamente), enquanto em GB prevaleceram os pais e mães com formação universitária (63\% e 68,5\%, respectivamente). Esse dado mostra que os estudantes de GB possuem vantagens em termos de capital cultural, em decorrência da experiência vicariante de ingresso em uma carreira acadêmica no âmbito familiar, sugerindo uma maior proximidade dessa jovem com o contexto universitário. Dados desse quadro dão indícios de que a configuração da amostra do Grupo A já é fruto da seleção do sistema educacional e apresenta uma configuração diferenciada em relação a outros com histórico de exclusão.

\subsubsection{Ocupação dos Pais e das Mães}

As ocupações declaradas pelos pais e pelas mães foram classificadas, com base nos critérios adotados por Graciano, Lehfeld e Neves Filho (1999). A saber, para fins do presente estudo, optou-se pela classificação em quatro categorias (A) corresponde a carreiras universitárias, incluindo altos cargos de chefia; (B) prestação de serviços - comércio, lidar com público, rotina de escritório; (C) a atividades técnicas, artesanais, braçais; e (D) desempregados, falecidos, aposentados e dono ou dona de casa. Ressalta-se que pelo fato de alguns dos pais e mães exercerem mais de uma ocupação, além de que nem todos os questionários foram respondidos na íntegra, o total de profissões descritas para os pais e para a mães variou de 41 a 47. Serão apresentados inicialmente os dados dos PAIS, 
respectivamente do Grupo A e do Grupo B; seguidos pelos das MÃES, apresentados na mesma ordem (Grupo A e Grupo B).

Preencheram o quadro referente à ocupação dos pais, $81 \%$ do Grupo A e $87 \%$ do GB. No Grupo A (Tabela 9) evidencia a participação, predominantemente, em atividades classificadas na categoria $\mathrm{C}(37,7 \%)$, que correspondem a atividades técnicas, artesanais, braçais; destacando-se as seguintes ocupações: motorista $(n=3)$, operador de maquinário $(n=2)$, pedreiro $(n=2)$ e vigilante $(n$ =2). A segunda categoria mais representativa dos pais do GA (Tabela 9) é categoria B $(24,5 \%)$, de prestação de serviços, destacando-se a ocupação de comerciante $(\mathrm{n}=5)$ e a de funcionário público $(\mathrm{n}$ $=2)$

Tabela 9 - Categorização e freqüência da ocupação atual dos PAIS do Grupo A

\begin{tabular}{|c|c|c|c|c|}
\hline \multirow{2}{*}{ CATEGORIAS } & \multirow{2}{*}{ OCUPAÇÕES } & \multirow{2}{*}{ Freqüência } & \multicolumn{2}{|c|}{ TOTAL } \\
\hline & & & $\mathrm{n}$ & $\%$ \\
\hline \multirow{3}{*}{$A$} & Administrador & 3 & \multirow{3}{*}{5} & \multirow{3}{*}{9,4} \\
\hline & Advogado & 1 & & \\
\hline & Contador & 1 & & \\
\hline \multirow{8}{*}{ B } & Comerciante & 5 & \multirow{8}{*}{13} & \multirow{8}{*}{24,5} \\
\hline & Microempresário & 1 & & \\
\hline & Líder de setor & 1 & & \\
\hline & Representante comercial & 1 & & \\
\hline & Empresário & 1 & & \\
\hline & Despachante & 1 & & \\
\hline & Funcionário Público & 2 & & \\
\hline & Autônomo & 1 & & \\
\hline \multirow{15}{*}{$\mathrm{C}$} & Agricultor & 1 & \multirow{15}{*}{20} & \multirow{15}{*}{37,7} \\
\hline & Açougueiro & 1 & & \\
\hline & Arte final em oficina & 1 & & \\
\hline & Borracheiro & 1 & & \\
\hline & Marceneiro & 1 & & \\
\hline & Metalúrgico & 1 & & \\
\hline & Motorista & 3 & & \\
\hline & Operador de maquinário & 2 & & \\
\hline & Pedreiro & 2 & & \\
\hline & Porteiro & 1 & & \\
\hline & Segurança & 1 & & \\
\hline & Soldador & 1 & & \\
\hline & Vigilante & 2 & & \\
\hline & Encarregado de depósito & 1 & & \\
\hline & Garçom & 1 & & \\
\hline \multirow[b]{2}{*}{$\mathrm{D}$} & Aposentado & 4 & \multirow[b]{2}{*}{5} & \multirow[b]{2}{*}{9,4} \\
\hline & Desempregado & 1 & & \\
\hline Sem resposta & & & 10 & 18,9 \\
\hline TOTAL & & & 53 & 100 \\
\hline
\end{tabular}

Por sua vez, os pais do grupo B (Tabela 10) estão inseridos no mercado de trabalho nas categorias A $(42,6 \%)$, com destaque para as carreiras universitárias de administrador $(\mathrm{n}=5)$, 
engenheiro $(n=5)$ e médico $(n=3)$. Na seqüência, a categoria B $(25,9 \%)$ apresenta-se como mais representativa, com destaque para as ocupações de comerciante $(n=7)$ e de profissional liberal $(n=$ $3)$.

Tabela 10 - Categorização e freqüência da ocupação atual dos PAIS do Grupo B

\begin{tabular}{|c|c|c|c|c|}
\hline CATEGORIAS & OCUPAÇÕES & Freqüência & & TOTAL \\
\hline \multirow{10}{*}{ 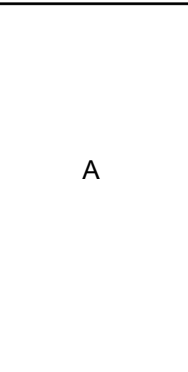 } & Advogado & 1 & \multirow{10}{*}{23} & \multirow{10}{*}{42,6} \\
\hline & Administrador & 5 & & \\
\hline & Biomédico & 1 & & \\
\hline & Contador & 1 & & \\
\hline & Engenheiro & 5 & & \\
\hline & Analista de Sistemas & 1 & & \\
\hline & Médico & 3 & & \\
\hline & Diretor de empresa & 2 & & \\
\hline & Procurador público & 1 & & \\
\hline & Professor (com formação acadêmica) & 3 & & \\
\hline \multirow{6}{*}{ B } & Bancário & 1 & \multirow{6}{*}{14} & \multirow{6}{*}{25,9} \\
\hline & Funcionário público & 1 & & \\
\hline & Profissional Liberal & 3 & & \\
\hline & Comerciante & 7 & & \\
\hline & Microempresário & 1 & & \\
\hline & Representante comercial & 1 & & \\
\hline \multirow{3}{*}{$\mathrm{C}$} & Agricultor & 1 & \multirow{3}{*}{4} & \multirow{3}{*}{7,4} \\
\hline & Agropecuarista & 1 & & \\
\hline & Operador de máquinas & 2 & & \\
\hline \multirow[b]{2}{*}{$\mathrm{D}$} & Aposentado & 5 & \multirow[b]{2}{*}{6} & \multirow[b]{2}{*}{11,1} \\
\hline & Falecido & 1 & & \\
\hline Sem respostas & & 7 & 7 & 13 \\
\hline TOTAL & & & 54 & 100 \\
\hline
\end{tabular}

No Grupo A (Tabela 11), observa-se presença predominante nas categorias C (30,2\%) com destaque para a ocupação de diarista/doméstica $(n=6)$, e a categoria $\mathrm{D},(28,3 \%)$, com quase totalidade da ocupação de dona de casa $(\mathrm{n}=14)$. 
Tabela 11 - Categorização e freqüência de resposta dada à ocupação atual das MÃES do Grupo A

\begin{tabular}{|c|c|c|c|c|}
\hline \multirow[t]{2}{*}{ CATEGORIAS } & \multirow[t]{2}{*}{ OCUPAÇÕES } & \multirow[t]{2}{*}{ Freqüência } & \multicolumn{2}{|c|}{ TOTAL } \\
\hline & & & $\mathrm{n}$ & $\%$ \\
\hline A & Enfermeira & 2 & 2 & 3,8 \\
\hline \multirow{4}{*}{ B } & Assistente administrativa & 2 & \multirow{4}{*}{7} & \multirow{4}{*}{13,2} \\
\hline & Pequena proprietária & 1 & & \\
\hline & Funcionária pública & 1 & & \\
\hline & Professora de pintura & 1 & & \\
\hline \multirow{8}{*}{$\mathrm{C}$} & Auxiliar (de produção/ enfermagem) & 2 & \multirow{8}{*}{17} & \multirow{8}{*}{32} \\
\hline & Colhedora de citrus & 1 & & \\
\hline & Copeira & 1 & & \\
\hline & Costureira & 1 & & \\
\hline & Cozinheira & 1 & & \\
\hline & Operadora de caixa & 1 & & \\
\hline & Serviços gerais & 2 & & \\
\hline & Diarista/doméstica & 6 & & \\
\hline \multirow[b]{2}{*}{$\mathrm{D}$} & Desempregada & 1 & \multirow[b]{2}{*}{15} & \multirow[b]{2}{*}{28,3} \\
\hline & Dona de casa & 14 & & \\
\hline Sem respostas & & & 12 & 22,6 \\
\hline TOTAL & & & 53 & 100 \\
\hline
\end{tabular}

Já no Grupo B (Tabela 12), houve prevalência das ocupações das categorias B (40,7\%), em que se destacam as ocupações de professoras $(n=8)$, comerciante $(n=4)$ e funcionária pública $(n=$ 3). A categoria seguinte trata-se da A (24\%), na qual se destacam carreiras universitárias, com destaque para a ocupação de médica $(n=3)$. 
Tabela 12. Categorização e freqüência de resposta dada à ocupação atual das MÃES do Grupo B

\begin{tabular}{|c|c|c|c|c|}
\hline CATEGORIAS & OCUPAÇÕES & Freqüência & & TOTAL \\
\hline \multirow{10}{*}{ A } & Administradora & 1 & \multirow{10}{*}{13} & \multirow{10}{*}{24} \\
\hline & Advogada & 1 & & \\
\hline & Agente administrativa & 1 & & \\
\hline & Assistente social & 1 & & \\
\hline & Dentista & 1 & & \\
\hline & Diretora administrativa & 1 & & \\
\hline & Fonoaudióloga & 1 & & \\
\hline & Médica & 3 & & \\
\hline & Pedagoga & 1 & & \\
\hline & Terapeuta Holística & 1 & & \\
\hline \multirow{9}{*}{ B } & Comerciante & 4 & \multirow{9}{*}{22} & \multirow{9}{*}{40,7} \\
\hline & Funcionária pública & 3 & & \\
\hline & Gerente de vendas & 1 & & \\
\hline & Professora & 8 & & \\
\hline & Recepcionista & 1 & & \\
\hline & Técnica do Judiciário & 1 & & \\
\hline & Profissional liberal & 1 & & \\
\hline & Protética & 2 & & \\
\hline & Técnica de laboratório & 1 & & \\
\hline $\mathrm{C}$ & Artesanato & 1 & 1 & 1,8 \\
\hline \multirow{3}{*}{ D } & Aposentada & 1 & \multirow{3}{*}{9} & \multirow{3}{*}{16,7} \\
\hline & Desempregada & 3 & & \\
\hline & Dona de casa & 5 & & \\
\hline Sem resposta & & 9 & 9 & 16,7 \\
\hline TOTAL & & & 54 & 100 \\
\hline
\end{tabular}

Nota-se que a maioria das carreiras universitárias das mães do GB é tipicamente feminina (assistente social, fonoaudióloga, terapeuta holística, pedagoga), além de aparecerem também ocupações em carreiras mais tradicionais (advogada, médicas, dentistas) e uma em cargo de chefia (diretora administrativa). Comparando-se o quadro de ocupações (Tabela 12) com os dados de escolarização das mães (Tabela 8) pode-se notar que o número de mães que alcançaram o nível de ensino superior é maior do que o daquelas que exercem ocupações ditas universitárias (categoria A). Esse dado parece indicar dificuldades enfrentadas pelas mães em se lançarem profissionalmente nas carreiras universitárias que escolheram para sua formação, e, ou dificuldades na procura e obtenção de trabalho. Porém, cabe ressaltar que algumas das ocupações enquadradas pelo presente estudo como de "prestação de serviço" (categoria B), como as ocupações de "professora" ou "comerciante", podem sugerir uma formação anterior de nível universitário, respectivamente as carreiras de pedagoga e administradora. 


\subsection{Opiniões dos Participantes com relação às Cotas Universitárias}

A seguir serão apresentados e discutidos os resultados, a partir do cruzamento da variável sexo seguido da variável da natureza do curso pré-vestibular com os temas centrais do questionário, categorizados em:

1. Vestibular (12a, 12b, 12c, 12d, 18e, 18g, 18h e questão 16),

2. Cotas Universitárias (questões 17, 17.1, 17.2, 18a, 18b, 18c, 18d, 18f e 19),

3. Medidas Governamentais de acesso ao Ensino Superior (13b, 13c, 13d e 15c), e

4. Questão Racial (13a, 15a, 15b, 15d, 15e, 15f, 15g, 15h, 15i e questão 14).

\subsubsection{Sexo e Vestibular}

Entre as mulheres, $60 \%$ discordam da afirmação “O vestibular é um método justo para selecionar aqueles que têm capacidade de entrar numa universidade" (12a), enquanto 54,8\% dos homens concordam (Tabela 13). Há um relativo consenso sobre o enunciado "Estudantes ricos têm mais chance de entrar numa boa universidade do que estudantes pobres" (12b), 81,5\% das moças e $81 \%$ dos rapazes concordam com tal afirmação. Ambos os grupos dão ênfase aos contextos ambientais (LENT, HACKETT \& BROWN, 1994), ou seja, as expectativas dos participantes atribuem valor positivo à contexto socioeconômico dos mais abastados. 
Tabela 13 - Distribuição das respostas por sexo e resultado do Qui-quadrado nas respostas envolvendo atitudes frente à temática vestibular.

\begin{tabular}{|c|c|c|c|c|c|c|c|c|c|}
\hline & \multicolumn{4}{|c|}{ Moças } & \multicolumn{4}{|c|}{ Rapazes } & \multirow{3}{*}{$\begin{array}{l}\text { Qui-quadrado e } \\
\text { Significância }\end{array}$} \\
\hline & \multicolumn{2}{|c|}{ concorda } & \multicolumn{2}{|c|}{ discorda } & \multicolumn{2}{|c|}{ concorda } & \multicolumn{2}{|c|}{ discorda } & \\
\hline & $\mathrm{n}$ & $\%$ & $\mathrm{n}$ & $\%$ & $\mathrm{n}$ & $\%$ & $\mathrm{n}$ & $\%$ & \\
\hline $\begin{array}{l}\text { (12a) O vestibular é um método justo para } \\
\text { selecionar aqueles que têm capacidade de entrar } \\
\text { numa universidade. }\end{array}$ & 26 & 40 & 39 & 60 & 23 & 54,8 & 19 & 45,2 & $\begin{array}{l}x^{2}=3,17 \\
p=0,37\end{array}$ \\
\hline $\begin{array}{l}\text { (12b) Estudantes ricos têm mais chance de entrar } \\
\text { numa boa universidade do que estudantes } \\
\text { pobres. }\end{array}$ & 53 & 81,5 & 12 & 18,5 & 34 & 81 & 8 & 19 & $\begin{array}{l}X^{2}=0,60 \\
p=0,90\end{array}$ \\
\hline $\begin{array}{l}\text { (12c) Estudantes brancos têm mais chance de } \\
\text { entrar numa boa universidade do que estudantes } \\
\text { pobres. }\end{array}$ & 19 & 29,3 & 46 & 70,7 & 19 & 45,2 & 23 & 54,8 & $\begin{array}{l}X^{2}=3,26 \\
p=0,35\end{array}$ \\
\hline $\begin{array}{l}\text { (12d) Estudantes entram numa boa Universidade } \\
\text { apenas por seus próprios méritos e esforços. }\end{array}$ & 44 & 67,7 & 21 & 32,3 & 22 & 52,4 & 20 & 47,7 & $\begin{array}{l}X^{2}=2,76 \\
p=0,43\end{array}$ \\
\hline $\begin{array}{l}\text { (18e) Na Univ., além do vestibular, deveria } \\
\text { também levar em conta na seleção as dificuldades } \\
\text { enfrentadas pelos candidatos devido às suas } \\
\text { condições sociais e raciais. }\end{array}$ & 28 & 43,1 & 37 & 56,9 & 25 & 59,5 & 17 & 40,5 & $\begin{array}{l}X^{2}=4,93 \\
p=0,18\end{array}$ \\
\hline $\begin{array}{l}\text { (18g) O vestibular realiza uma seleção injusta e } \\
\text { deveria ser modificado. }\end{array}$ & 51 & 79,7 & 13 & 20,3 & 23 & 54,8 & 19 & 45,2 & $\begin{array}{l}X^{2}=7,60 \\
p=0,02^{*}\end{array}$ \\
\hline (18h) O vestibular é injusto e deve ser extinto. & 18 & 19 & 44 & 81 & 16 & 38,1 & 26 & 61,9 & $\begin{array}{c}X^{2}=3,00 \\
p=0,39\end{array}$ \\
\hline
\end{tabular}

$(*)$ diferença significativa

Com relação ao determinante étnico-racial, que corresponde aos indutos pessoais, $70,7 \%$ das moças e $54,8 \%$ dos rapazes, discordam que estudantes brancos tenham mais chances de ingresso em uma boa universidade do que estudantes negros (12c). No item sobre mérito (12d), 67,7\% das moças e $61,7 \%$ dos rapazes concordam com a afirmação "Estudantes entram numa boa universidade apenas por seus próprios méritos e esforços". Observa-se, portanto que, na opinião desses jovens, a entrada no ensino superior de qualidade é determinada mais fortemente pela questão socioeconômica (meios contextuais de fundo) e a meritocrática (crenças de auto-eficácia) do que por critérios especificamente étnico-raciais (indutos pessoais).

No item 18e, que sugere um critério não-meritocrático de seleção para a universidade, com a afirmação "a universidade, além do vestibular, deveria também levar em conta na seleção as dificuldades enfrentadas pelos candidatos devido às suas condições sociais e raciais", $56,9 \%$ das mulheres discordam versus $59,5 \%$ dos homens que concordam com o novo critério de seleção. O item $18 \mathrm{~g}$, em que se afirma “O vestibular realiza uma seleção injusta e deveria ser modificado”, foi o único 
nesse conjunto de dados sobre vestibular a apresentar diferença estatística significativa $\left(X^{2}=7,60\right.$ e $p$ $=0,02 *)$, de modo que o percentual de mulheres que concordam da afirmação $(79,7 \%)$ é significativamente superior ao percentual dos homens (54,8\%). Já quanto à afirmação mais radical sobre o exame vestibular, $81 \%$ da moças e $68,2 \%$ dos rapazes discordam de que "O vestibular é injusto e deve ser extinto" (18h). Na questão 16 (Tabela 14), pergunta-se "o que acontecerá se uma pessoa, vinda de escola pública, estudar bastante para vestibulares de universidades federais e públicas", sendo que a resposta mais votada foi "provavelmente ela conseguirá ingressar no curso desejado se realmente se esforçar, ainda que não seja fácil” (76,6\% da moças e $66,7 \%$ dos rapazes). Ou seja, prevalece a idéia de que o esforço individual é condição essencial para os que pretendem atingir sucesso em qualquer carreira acadêmica.

Tabela 14 - Distribuição das respostas por sexo nas respostas dadas à questão sobre a temática relativa à oportunidade de ingresso nas universidades públicas para alunos do ensino médio público.

\begin{tabular}{|c|c|c|c|c|}
\hline \multirow{3}{*}{$\begin{array}{l}\text { Quest16. O que acontecerá se uma pessoa, vinda de escola pública, estudar bastante para vestibulares } \\
\text { de universidades federais e públicas }\end{array}$} & \multicolumn{4}{|c|}{ Sexo } \\
\hline & \multicolumn{2}{|c|}{ Moças } & \multicolumn{2}{|c|}{ Rapazes } \\
\hline & $\mathrm{n}$ & $\%$ & $\mathrm{n}$ & $\%$ \\
\hline $\begin{array}{l}\text { Provavelmente ela conseguirá ingressar no curso desejado se realmente se esforçar, ainda que não } \\
\text { seja fácil. }\end{array}$ & 49 & 76,6 & 28 & 66,7 \\
\hline $\begin{array}{l}\text { Não importa o esforço que ela faça, dificilmente ela terá chances de ingressar em cursos muito } \\
\text { concorridos }\end{array}$ & 2 & 3,1 & 3 & 7,1 \\
\hline $\begin{array}{l}\text { Talvez ela até consiga ingressar em alguma universidade, mas apenas nos cursos onde a concorrência } \\
\text { é baixa. }\end{array}$ & 6 & 9,4 & 3 & 7,1 \\
\hline Depende da capacidade da pessoa. & 7 & 7 & 8 & 19 \\
\hline Não sei. & - & - & - & - \\
\hline TOTAL & 64 & 100 & 42 & 100 \\
\hline
\end{tabular}

(*) diferença significativa

De acordo com Modelo de Escolha da Carreira de Lent, Brown e Hackett (1994), os dados acima permitem afirmar que a perspectiva dos participantes, de ambos os sexos, sobre o vestibular focaliza as elevadas crenças de auto-eficácia e as expectativas de resultados positivos (princípios auto-regulatórios) como variáveis diretamente relacionadas ao bom desempenho nas provas. Dessa forma, se houver sucesso diante do vestibular (experiência de aprendizagem), tais expectativas se 
confirmarão; caso contrário, o fracasso levará a uma reavaliação de praticamente todas as etapas do processo de escolha.

\subsubsection{Sexo e Cotas Universitárias}

As questões 17, 17.1, 17.2, 18a, 18b, 18c, 18d, 18f e 19 trazem informações sobre critérios dos sistemas de cotas universitárias em funcionamento, implementação ou que se encontram tramitando na Assembléia Legislativa Federal e/ou nas Estaduais e Câmaras Municipais. Na questão 17, pergunta-se se os participantes sabem da existência de pelo menos 14 instituições que operam com regime de cotas, com reserva de vagas para alunos vindos de escolas públicas, em especial para afro-descentes e indígenas. Com relação a essa questão, em que $X^{2}=7,15$ e p $=$ $0,007^{*}$, verifica-se que as meninas apresentam um percentual significativamente superior ao dos meninos $(84,6 \%$ e $61,9 \%)$, ou seja, estão mais informadas sobre o assunto. No item 17.1, pergunta-se qual o posicionamento dos participantes sobre esses programas. Nesse item não há diferença significativa $\left(\mathrm{X}^{2}=0,38 \mathrm{e} \mathrm{p}=0,83\right)$ sendo que prevalecem os que discordam, sendo $56,9 \%$ das moças e $52,4 \%$ dos rapazes. Somam $32,3 \%$ das moças e $38,1 \%$ dos rapazes os que concordam. Os demais $10,8 \%$ das moças e $9,5 \%$ dos rapazes correspondem aos que "não sabem" ou "não tem informação a respeito". Em 17.2, solicita-se ao participante que defina melhor seu posicionamento anterior, colocando qual critério para os programas de cotas seria melhor (Tabela

\begin{tabular}{|l|c|c|c|c|}
\hline & \multicolumn{3}{|c|}{ Sexo } \\
\hline & \multicolumn{3}{|c|}{ Moças } & \multicolumn{2}{c|}{ Rapazes } \\
\cline { 2 - 5 } & $\mathrm{n}$ & \multicolumn{2}{|c|}{$\mathrm{n}$} & \multicolumn{2}{|c|}{$\%$} \\
\hline Só para Negros e Indígenas & 1 & 1,6 & 1 & 2,4 \\
\hline Só para alunos de escola pública & 27 & 42,2 & 15 & 35,7 \\
\hline Negros, Indígenas e alunos de escola pública & 10 & 15,6 & 13 & 31 \\
\hline Não deveria haver Cotas & 26 & 40,6 & 13 & 31 \\
\hline TOTAL & 64 & 100 & 42 & 100 \\
\hline
\end{tabular}

$15)$.

Tabela 15 - Distribuição por sexo das repostas sobre qual seria o critério mais aceito a ser incorporado a programas de Cotas Universitárias. 
Nesse item, para a análise estatística de correlação foi preciso excluir a categoria de resposta "só para negros e índios", eleitas por apenas uma moça e um rapaz. Não houve diferença significativa $\left(\mathrm{X}^{2}=3,66\right.$ e $\left.\mathrm{p}=0,16\right)$. As opiniões se dividem: entre as moças, as respostas mais votadas foram: 42,2\% opinam que seria melhor se fossem "só para alunos de escola pública", 40,6\% respondem que "não deveria haver cotas" e 15,6\% que deveriam ser para "para negros, índios e alunos de escola pública". Entre os rapazes: 35,7\% opinam "só para alunos de escola pública", sendo 31\% respondem que "não deveria haver cotas"; e outros $31 \%$ concordam que deveriam ser "para negros, índios e alunos de escola pública”. Ou seja, apesar de não haver consenso sobre o melhor critério a ser adotado, o menos aceito pelos participantes é o critério étnico-racial isolado de outros ("só para negros e índios"), somando 1,6\% entre as mulheres e 2,4\% entre os homens.

Outra questão específica sobre o sistema de cotas trata-se da questão 19 , que cita o modelo de Cotas sugerido pelo Projeto de Lei Federal 3627/2004, perguntando aos participantes se os mesmos concordam ou não. Entre as mulheres, 49,2\% discordam, 33,8\% concordam e 16,9\% ainda não se posicionaram a respeito. Já entre os homens, 47,6\% concordam, 45,2\% discordam e outros 7,1\% ainda não sabem. Nota-se, portanto, que não há consenso entre os participantes sobre programas desse tipo. Essa dispersão de opiniões tanto pode evidenciar a polêmica em torno do tema como ser decorrente de falta de informação sobre política de ação afirmativa, em especial de reserva de cotas universitárias.

Os itens 18a à 18f (Tabela 16) trazem reflexões sobre as políticas de cotas, em âmbito geral. Sobre se "políticas de cotas raciais é uma boa forma de corrigir desigualdades raciais históricas" (18a), discordam $76,9 \%$ das moças e $69,1 \%$ dos rapazes.

Tabela 16 - Distribuição das respostas por sexo dadas aos itens do questionário COTAS referentes à temática das Cotas Universitárias

\begin{tabular}{|c|c|c|c|c|c|c|c|c|c|}
\hline \multirow{3}{*}{ Itens } & \multicolumn{4}{|c|}{ Moças } & \multicolumn{4}{|c|}{ Rapazes } & \multirow{3}{*}{$\begin{array}{l}\text { Qui-quadrado e } \\
\text { Significância }\end{array}$} \\
\hline & \multicolumn{2}{|c|}{ Concorda } & \multicolumn{2}{|c|}{ Discorda } & \multicolumn{2}{|c|}{ concorda } & \multicolumn{2}{|c|}{ discorda } & \\
\hline & $\mathrm{n}$ & $\%$ & $\mathrm{n}$ & $\%$ & $\mathrm{n}$ & $\%$ & $\mathrm{n}$ & $\%$ & \\
\hline $\begin{array}{l}\text { (18a) Políticas de cotas raciais é uma boa forma de } \\
\text { corrigir desigualdades raciais históricas. }\end{array}$ & 15 & 23,1 & 50 & 76,9 & 13 & 30,9 & 29 & 69,1 & $\begin{array}{l}X^{2}=2,53 \\
p=0,47\end{array}$ \\
\hline $\begin{array}{l}\text { (18b) Políticas de cotas raciais deveriam ser adotadas } \\
\text { junto com um maior investimento na educação básica }\end{array}$ & 35 & 54,7 & 29 & 45,3 & 31 & 73,8 & 11 & 26,2 & $\begin{array}{l}X^{2}=6,14 \\
p=0,05^{*}\end{array}$ \\
\hline
\end{tabular}




\begin{tabular}{lccccccccc}
\hline (18c) Melhor seria investir na educação básica. & 60 & 92,3 & 5 & 7,7 & 42 & 100 & - & - & $p=0,15$ \\
\hline $\begin{array}{l}\text { (18d) As pessoas deveriam entrar na universidade } \\
\text { somente por seus méritos e esforços próprios. }\end{array}$ & 53 & 81,5 & 12 & 18,4 & 28 & 90 & 12 & 10 & $\begin{array}{c}X^{2}=9,59 \\
p=0,008^{*}\end{array}$ \\
\hline $\begin{array}{l}\text { (18f) As pessoas não deveriam entrar numa } \\
\text { universidade favorecidos por uma lei como a reserva de } \\
\text { vagas. }\end{array}$ & 41 & 63,1 & 24 & 36,9 & 24 & 57,2 & 18 & 42,8 & $\begin{array}{c}X^{2}=0,49 \\
p=0,78\end{array}$ \\
\hline
\end{tabular}

(*) diferença significativa

Nos dois itens seguintes $18 \mathrm{~b}$ e $18 \mathrm{~d}$ identificam-se diferenças significativas entre moças e rapazes.

$\mathrm{Na}$ afirmação de que essas políticas "deveriam ser adotadas junto com um maior investimento na Educação Básica" (18b), as opiniões femininas se dividem um pouco, sendo que 54,7\% concordam e 45,3\% discordam. Entre os rapazes há maior consenso, já que 73,8\% concordam e $26,2 \%$ discordam. No item $18 \mathrm{~d}$, coloca-se em questão o valor atribuído pelos participantes ao mérito e aos esforços próprios. Nesse sentido, prevalecem as opiniões concordantes com a afirmação "as pessoas deveriam entrar na universidade somente por seus méritos e esforços próprios” (18d), equivalendo a $81,5 \%$ das moças e $90 \%$ dos rapazes. No entanto, quando se coloca que "melhor seria investir na Educação Básica" (18c), sem se mencionar a existência de políticas de cotas, há um relativo consenso em ambos os grupos: concordam 92,3\% da moças e $100 \%$ dos rapazes. Comparando-se o item $18 \mathrm{~d}$ ao já referido $12 \mathrm{~d}$ (Tabela 13), pode-se observar que apesar de se tratar do mesmo tema (mérito e esforço individual no vestibular), em 12d, há uma afirmação sobre o vestibular e em 18d há uma suposição introduzida pelo verbo "deveriam”. Entre os rapazes houve diferença entre o que eles julgam ser melhor ( $90 \%$ concordam com 18d)) e entre o que acontece de fato (61,7\% concordam com $12 \mathrm{~d})$. Sobre se "as pessoas não deveriam entrar numa universidade favorecidos por uma lei como a reserva de vagas" (18f), concordam $63,1 \%$ das mulheres e $57,2 \%$ dos homens, o que chama atenção, visto que há incongruência com relação ao item 18d. A reserva de vagas (cotas) associa-se a uma situação que não evidencia o esforço de quem se insere na Universidade pelo mecanismo tradicional. Rapazes e moças provavelmente prefeririam, em sua maioria, ingressar por mérito que elevaria mais ainda a autoestima e a auto-eficácia. Mas, se por meios já conhecidos não há oportunidade, cabe ao Governo e não ao vestibular intervir, como se observa na seção subseqüente. 


\subsubsection{Sexo e Medidas Governamentais de acesso ao ensino superior}

As afirmações 13b, 13c, 13d e 15c tangem a temática do papel do Estado na mediação de políticas como as cotas. Em 13b, afirma-se que "Igualdade de oportunidades para brancos e negros é algo importante, mas não é realmente uma função do governo garanti-la”. Discordam dessa colocação 64\% das moças e 61,9\% dos rapazes (Tabela 17). Em sentido inverso, o item 13c apresenta que "O governo federal deve fazer de tudo que puder para melhorar as condições sociais e econômicas dos negros", de modo que concordam com essa afirmação $72,3 \%$ das mulheres e $88,1 \%$ dos homens.

Tabela 17 - Distribuição das respostas por sexo dadas aos itens do questionário COTAS referentes à temática das Medidas Governamentais de acesso ao Ensino Superior

\begin{tabular}{|c|c|c|c|c|c|c|c|c|c|}
\hline & \multicolumn{4}{|c|}{ Moças } & \multicolumn{4}{|c|}{ Rapazes } & \multirow{3}{*}{$\begin{array}{l}\text { Qui-quadrado e } \\
\text { Significância }\end{array}$} \\
\hline & \multicolumn{2}{|c|}{ Concorda } & \multicolumn{2}{|c|}{ discorda } & \multicolumn{2}{|c|}{ concorda } & \multicolumn{2}{|c|}{ discorda } & \\
\hline & $\mathrm{n}$ & $\%$ & $n$ & $\%$ & $n$ & $\%$ & $\mathrm{~N}$ & $\%$ & \\
\hline $\begin{array}{l}\text { (13b) lgualdade de oportunidades para brancos e } \\
\text { negros é algo importante, mas não é realmente uma } \\
\text { função do governo garanti-la. }\end{array}$ & 23 & 36 & 41 & 64 & 16 & 38,1 & 26 & 61,9 & $\begin{array}{l}X^{2}=1,47 \\
p=0,69\end{array}$ \\
\hline $\begin{array}{l}\text { (13c) O governo federal deve fazer de tudo que puder } \\
\text { para melhorar as condições sociais e econômicas dos } \\
\text { negros }\end{array}$ & 47 & 72,3 & 18 & 27,7 & 37 & 88,1 & 5 & 11,9 & $\begin{array}{l}X^{2}=4,66 \\
p=0,20\end{array}$ \\
\hline $\begin{array}{l}\text { (13d) O governo não deve fazer nenhum esforço } \\
\text { especial para ajudar os negros porque eles mesmos } \\
\text { devem se ajudar }\end{array}$ & 10 & 15,6 & 54 & 84,4 & 4 & 9,5 & 38 & 90,5 & $\begin{array}{l}X^{2}=1,06 \\
p=0,58\end{array}$ \\
\hline $\begin{array}{l}\text { (15c) Japoneses, alemães, italianos e outros } \\
\text { imigrantes superaram as dificuldades e progrediram } \\
\text { socialmente no Brasil. Os negros deveriam fazer o } \\
\text { mesmo sem precisar de nenhum favor por parte do } \\
\text { Estado ou da sociedade. }\end{array}$ & 28 & 43,1 & 37 & 56,9 & 14 & 33,3 & 28 & 66,7 & $\begin{array}{l}X^{2}=2,25 \\
p=0,52\end{array}$ \\
\hline
\end{tabular}

Analogamente, quanto à afirmação de que "O governo não deve fazer nenhum esforço especial para ajudar os negros porque eles mesmos devem se ajudar" (13d) a grande maioria discorda, representando $84,4 \%$ das moças e 90,5\% dos rapazes. Na colocação seguinte (15c), faz uma analogia comparando diferentes grupos étnicos brasileiros, afirmando-se que já que "Japoneses, alemães, italianos e outros imigrantes superaram as dificuldades e progrediram socialmente no Brasil”, logo “os negros deveriam fazer o mesmo sem precisar de nenhum 
favor por parte do Estado ou da sociedade". Discordam dessa afirmação 56,9\% das mulheres e $66,7 \%$ dos homens.

Sobre esse tema, pode-se concluir que há, entre ambos os sexos, a consciência de que iniciativas governamentais que tenham por fundamento reduzir as desigualdades entre grupos sociais são bem aceitas e que o Estado brasileiro deve assumir a responsabilidade de combate à discriminação racial. Ao mesmo tempo discordam de que tais iniciativas sejam colocadas no âmbito dos critérios de seleção para o ensino superior (18f). O fato de não haver diferença significativa determinada pelo sexo sobre essa temática pode indicar a RS desse grupo sobre a responsabilidade do governo em garantir condições de equidade étnico-racial, possivelmente ancorada na origem histórica da discriminação e na omissão do estado em produzir no passado mecanismos de integração dos negros na sociedade após a abolição da escravatura.

\subsubsection{Sexo e Questão Racial}

Tratam da questão racial os itens: $15 \mathrm{a}, 15 \mathrm{~b}, 15 \mathrm{~d}, 15 \mathrm{e}, 15 \mathrm{f}, 15 \mathrm{~g}, 15 \mathrm{~h}, 15 \mathrm{i}$ e 14 . Na questão 14 (Tabela 18), a resposta mais freqüente, tanto no grupo de moças quanto no de rapazes, foi a alternativa que atribuía ao "preconceito e a discriminação que existe contra negros", respectivamente $68,7 \%$ e $50 \%$ o principal motivo que faz com que a população negra viva condições piores do que a população branca.

Tabela 18 - Distribuição das respostas, de acordo com o sexo, dadas à questão sobre o principal motivo que leva a população negra a viver em piores condições que a população branca, de acordo com o sexo.

\begin{tabular}{|c|c|c|c|c|}
\hline \multirow{3}{*}{$\begin{array}{l}\text { "De acordo com dados estatísticos, os negros recebem um salário menor que os brancos e são } 68 \% \text { daqueles } \\
\text { que vivem abaixo da linha de pobreza no Brasil. Na sua opinião, qual o principal motivo que leva a população } \\
\text { negra a viver em piores condições que a população branca? }\end{array}$} & \multicolumn{4}{|c|}{ Sexo } \\
\hline & \multicolumn{2}{|c|}{ Moças } & \multicolumn{2}{|c|}{ Rapazes } \\
\hline & $\mathrm{n}$ & $\%$ & $\mathrm{n}$ & $\%$ \\
\hline O preconceito e a discriminação que existe contra negros. & 44 & $\begin{array}{c}68 \\
7\end{array}$ & 21 & 50 \\
\hline Os negros que não aproveitam as oportunidades que têm para melhorar de vida. & 1 & 1,6 & 1 & 2,4 \\
\hline A falta de mão-de-obra qualificada negra. & 5 & 7,8 & 3 & 7,1 \\
\hline Falta de políticas por parte do governo. & 4 & 6,3 & 4 & 9,6 \\
\hline Outra resposta. & 6 & 9,4 & 10 & $\begin{array}{c}23 \\
8\end{array}$ \\
\hline Não sei. & 4 & 6,2 & 3 & 7,1 \\
\hline TOTAL & 64 & 100 & 42 & 100 \\
\hline
\end{tabular}

Outra afirmação associa o desempenho e sucesso profissional a condições favoráveis do meio, 
em que se diz que "Se pudessem comer bem e estudar numa boa escola, os negros sempre teriam sucesso profissional" (15a), é rejeitada por 51,6\% das moças e aceita por 57,1\% dos rapazes (Tabela 19). Sobre a afirmação "Toda raça tem gente competente e incompetente, isso não depende da cor da pele" (15b) concordam majoritários 100\% das mulheres e 85,2\% dos homens. Concordam que "Anos de escravidão e discriminação criaram condições que tornaram difíceis para os negros conseguirem sair da pobreza" (15e) 75,4\% das moças e 88,1\% dos rapazes. No item 15f, foi unânime a opinião de ambos os sexos que discordam da afirmação de que os negros não enfrentam problemas relacionados à sua cor.

Tabela 19 - Distribuição das respostas dadas por sexo às afirmações referentes à temática Questão Racial.

\begin{tabular}{|c|c|c|c|c|c|c|c|c|c|}
\hline \multirow{3}{*}{ Itens } & \multicolumn{4}{|c|}{ Moças } & \multicolumn{4}{|c|}{ Rapazes } & \multirow{3}{*}{$\begin{array}{l}\text { Qui-quadrado e } \\
\text { Significância }\end{array}$} \\
\hline & \multicolumn{2}{|c|}{ concorda } & \multicolumn{2}{|c|}{ discorda } & \multicolumn{2}{|c|}{ concorda } & \multicolumn{2}{|c|}{ discorda } & \\
\hline & $n$ & $\%$ & $n$ & $\%$ & $\mathrm{n}$ & $\%$ & $N$ & $\%$ & \\
\hline $\begin{array}{l}\text { (15a) Se pudessem comer bem e estudar numa boa } \\
\text { escola, os negros sempre teriam sucesso profissional. }\end{array}$ & 31 & 48,4 & 33 & 51,6 & 24 & 57,1 & 18 & 42,9 & $\begin{array}{l}X^{2}=1,85 \\
p=0,61\end{array}$ \\
\hline $\begin{array}{l}\text { (15b) Toda raça tem gente competente e } \\
\text { incompetente, isso não depende da cor da pele. }\end{array}$ & 64 & 100 & - & - & 40 & 95,2 & 2 & 4,8 & $p=0,15$ \\
\hline $\begin{array}{l}\text { (15d) Empenho e esforço na vida oferecem pouca } \\
\text { garantia de sucesso para os negros }\end{array}$ & 14 & 21,5 & 51 & 78,5 & 15 & 35,7 & 27 & 64,3 & $\begin{array}{l}X^{2}=6,47 \\
p=0,04^{*}\end{array}$ \\
\hline $\begin{array}{l}\text { (15e) Anos de escravidão e discriminação criaram } \\
\text { condições que tornaram difíceis para os negros } \\
\text { conseguirem sair da pobreza. }\end{array}$ & 49 & 75,4 & 16 & 24,6 & 37 & 88,1 & 5 & 11,9 & $\begin{array}{l}X^{2}=3,20 \\
p=0,20\end{array}$ \\
\hline $\begin{array}{l}\text { (15f) Os negros não têm problemas relacionados a sua } \\
\text { cor. }\end{array}$ & - & - & 64 & 100 & - & - & 42 & 100 & $P=0,15$ \\
\hline $\begin{array}{l}\text { (15g) Os problemas dos negros são iguais àqueles } \\
\text { enfrentados pela maioria da população pobre. }\end{array}$ & 41 & 64,1 & 23 & 35,9 & 22 & 52,4 & 20 & 47,6 & $\begin{array}{l}X^{2}=9,76 \\
p=0,02^{*}\end{array}$ \\
\hline $\begin{array}{l}\text { (15h) No Brasil, brancos e negros são tratados de } \\
\text { forma diferenciada. }\end{array}$ & 53 & 81,5 & 12 & 18,5 & 38 & 90,5 & 4 & 9,5 & $\begin{array}{l}X^{2}=2,47 \\
p=0,29\end{array}$ \\
\hline $\begin{array}{l}\text { (15i) Não existe preconceito no Brasil, pois somos uma } \\
\text { nação miscigenada e sem conflitos raciais }\end{array}$ & 1 & 1,6 & 63 & 98,4 & 2 & 4,8 & 40 & 95,2 & $p=0,56$ \\
\hline
\end{tabular}

(*) diferença significativa

Associando questão social e questão racial, ainda de acordo com a Tabela 19, concordam que “os problemas dos negros são iguais àqueles enfrentados pela maioria da população pobre" 64,1\% das mulheres e $52,4 \%$ dos homens, ainda que admitam ( $81,5 \%$ das moças e $90,5 \%$ dos rapazes) que haja diferença no tratamento de negros e brancos no Brasil (15h), sem que se mencione a realidade social, apenas o aspecto étnico-racial. Como era de se esperar, uma expressiva maioria discorda de que sejamos “(...) uma nação miscigenada e sem conflitos raciais”, equivalendo a 98,4\% das mulheres e 95,2\% dos homens. Esses dados desmistificam tolerância étnico-racial do povo brasileiro como ideologia predominante e evidenciam outras configurações da identidade nacional. 
Em síntese, com relação a variável sexo e ao partir do tratamento estatístico frente às temáticas tratadas pelo questionário (Vestibular, Cotas, Ação do Governo e Questões Raciais) foi possível observar que o sexo exerceu pouca influência na determinação das opiniões emitidas, sendo que apresentaram diferença estatística significativa apenas três questões sobre as cotas $(17,18 \mathrm{~b}$ e 18d), duas sobre a questão racial (15d e 15g) e uma sobre o vestibular (18g).

\subsubsection{Tipo de cursinho e Vestibular}

Com relação ao enunciado "o vestibular é um método justo para selecionar quem tem capacidade de entrar na universidade" (12a), como mostra a Tabela 20, houve diferença significativa nas respostas determinadas pelo tipo de cursinho $\left(X^{2}=20,99 ; p<0,001\right)$, sendo que o percentual do GA que concordam é significativamente superior ao do GB (68\% versus $24,1 \%)$. Já no GB a maioria discorda da justiça desse método seletivo, deixando subentendida a insatisfação desses alunos com o exame, bem como a necessidade de alterações do mesmo.

Tabela 20. Distribuição das respostas dadas às afirmações referentes à temática vestibular, por modalidade de cursinho comunitário (Grupo A) ou curso particular (Grupo B).

\begin{tabular}{|c|c|c|c|c|c|c|c|c|c|}
\hline & \multicolumn{4}{|c|}{ GRUPO A } & \multicolumn{4}{|c|}{ GRUPO B } & \multirow{3}{*}{$\begin{array}{l}\text { Qui-quadrado e } \\
\text { Significância }\end{array}$} \\
\hline & \multicolumn{2}{|c|}{ concorda } & \multicolumn{2}{|c|}{ discorda } & \multicolumn{2}{|c|}{ concorda } & \multicolumn{2}{|c|}{ discorda } & \\
\hline & $\mathrm{n}$ & $\%$ & $\mathrm{n}$ & $\%$ & $\mathrm{n}$ & $\%$ & $\mathrm{n}$ & $\%$ & \\
\hline $\begin{array}{l}\text { (12a) O vestibular é um método justo para selecionar aqueles } \\
\text { que têm capacidade de entrar numa universidade. }\end{array}$ & 36 & 68 & 17 & $\begin{array}{c}32 \\
1\end{array}$ & 13 & 24,1 & 41 & 75,7 & $\begin{array}{l}X^{2}=20,99 \\
p<0,001^{*}\end{array}$ \\
\hline $\begin{array}{l}\text { (12b) Estudantes ricos têm mais chance de entrar numa boa } \\
\text { universidade do que estudantes pobres. }\end{array}$ & 38 & $\begin{array}{c}71 \\
7\end{array}$ & 15 & $\begin{array}{c}28 \\
3\end{array}$ & 49 & 90,7 & 5 & 9,3 & $\begin{array}{l}X^{2}=14,84 \\
p=0,01^{*}\end{array}$ \\
\hline $\begin{array}{l}\text { (12c) ) Estudantes brancos têm mais chance de entrar numa } \\
\text { boa universidade do que estudantes pobres. }\end{array}$ & 20 & $\begin{array}{l}37 \\
7\end{array}$ & 33 & $\begin{array}{l}62 \\
3\end{array}$ & 18 & 33,4 & 36 & 66,6 & $\begin{array}{l}X^{2}=0,27 \\
p=0,88\end{array}$ \\
\hline $\begin{array}{l}\text { (12d) Estudantes entram numa boa Universidade apenas por } \\
\text { seus próprios méritos e esforços. }\end{array}$ & 41 & $\begin{array}{c}77 . \\
3\end{array}$ & 12 & $\begin{array}{c}22 . \\
6\end{array}$ & 15 & 46,3 & 29 & 53,7 & $\begin{array}{l}X^{2}=20,99 \\
p<0,001^{*}\end{array}$ \\
\hline $\begin{array}{l}\text { (18e) } \mathrm{Na} \text { Univ., além do vestibular, deveria também levar em } \\
\text { conta na seleção as dificuldades enfrentadas pelos candidatos. }\end{array}$ & 36 & $\begin{array}{c}67 \\
8\end{array}$ & 17 & $\begin{array}{c}32 \\
2\end{array}$ & 17 & 31,5 & 37 & 68,5 & $\begin{array}{l}X^{2}=15,44 \\
p=0,001^{*}\end{array}$ \\
\hline $\begin{array}{l}\text { (18g) O vestibular realiza uma seleção injusta e deveria ser } \\
\text { modificado. }\end{array}$ & 33 & $\begin{array}{c}62 \\
3\end{array}$ & 20 & $\begin{array}{c}27 \\
8\end{array}$ & 41 & 77,4 & 12 & 22,6 & $\begin{array}{l}X^{2}=4,01 \\
p=0,14\end{array}$ \\
\hline (18h) O vestibular é injusto e deve ser extinto. & 13 & $\begin{array}{c}24 \\
5\end{array}$ & 40 & $\begin{array}{c}75 \\
4\end{array}$ & 21 & 41,2 & 20 & 58,8 & $\begin{array}{l}X 2=3,97 \\
p=0,27\end{array}$ \\
\hline
\end{tabular}

(*) diferença significativa 
Os resultados obtidos nas questões 12a e $12 \mathrm{~b}$ sinalizam uma contradição nas respostas no Grupo A, isto é, para eles o vestibular é justo (68\% concorda em algum grau), embora admitam que os ricos tenham mais chances do que os pobres $(71,7 \%)$, o que evidencia a apropriação da ideologia meritocrática dominante no cenário universitário brasileiro. As respostas do Grupo B apresentam-se mais coerentes, uma vez que para $75,9 \%$ o vestibular é injusto e que os ricos têm mais chances na visão de $90,7 \%$ dos respondentes deste grupo. Na questão 12c afirma-se que "estudantes brancos têm mais chances de entrar em uma boa universidade do que estudantes negros". A essa questão os resultados mostram que não houve diferença significativa entre os grupos $\mathrm{A}$ e $\mathrm{B}\left(\mathrm{X}^{2}=0,27, \mathrm{p}=0,88\right)$, de modo que concordam 70,7\% integrantes do GA; e 67\% do GB, como mostra a Tabela 20.

Sobre a idéia de que "estudantes entram em uma boa universidade apenas por seus próprios méritos" (12d), verificou-se que a porcentagem dos participantes dos cursinhos comunitários (GA) que concordam é significativamente superior ao dos particulares (GB) $(77,3 \% \mathrm{X} 46,3 \%)$, como mostra a Tabela 20, confirmando tanto a tendência dos grupos observada nas respostas anteriores aos itens 12a e 12b quanto a apropriação do discurso dominante por parte dos integrantes do Grupo A. Já no enunciado "a universidade, além do vestibular, deveria levar em conta na seleção as dificuldades enfrentadas pelos candidatos devido às suas condições sociais e raciais" (18e), traz a idéia de que no vestibular devem ser consideraras as dificuldades específicas dos candidatos. Nesse aspecto, com o $\mathrm{X}^{2}=15,44$ e o $\mathrm{p}=0,001$, confirma-se que no Grupo $\mathrm{A}$ o percentual dos que concordam ou concordam fortemente é superior ao Grupo B (67,9\% X 31,5\%). De acordo com as respostas dadas a esse item, pode-se identificar uma conduta dos participantes de defenderem os interesses próprios e do grupo.

Com o objetivo de avaliar o que os participantes pensam sobre políticas públicas que alterariam o modo de ingresso na universidade a questão $18 \mathrm{~g}$ pergunta se o "vestibular realiza uma seleção injusta e deveria ser modificado". A maioria dos participantes $(70 \%)$ concorda com essa afirmação (Tabela 20). Quando considerado por tipo de cursinho, no Grupo A esse índice cai para 
$62,3 \%$ contra $77,4 \%$ dos cursinhos particulares. "O vestibular é injusto e deveria ser extinto" (questão 18h), discordam ou discordam fortemente 75,4\% dos participantes do Grupo A (comunitários) versus 58,8\% dos participantes do Grupo B (particulares), como mostra Tabela 20. Não há diferença significativa nas respostas às duas questões (18g e 18h) quanto à natureza do cursinho.

Ainda sobre o vestibular, na questão 16 (Tabela 21) solicita-se que o respondente assinale uma única alternativa sobre o que aconteceria se um estudante de escola pública estudasse bastante para vestibulares de universidades federais e públicas.

Tabela 21 - Opinião dos Grupos A e B com relação à questão 16, que pergunta "O que acontecerá se uma pessoa, vinda de escola pública, estudar bastante para vestibulares de universidades federais e públicas". Sendo $\mathrm{X}^{2}=8,78$ e $\mathrm{p}=0,01^{*}$

\begin{tabular}{|c|c|c|c|c|}
\hline & \multicolumn{4}{|c|}{ Tipo de cursinho } \\
\hline & \multicolumn{2}{|c|}{ GRUPO A } & \multicolumn{2}{|c|}{ GRUPO B } \\
\hline & $\mathrm{n}$ & $\%$ & $\mathrm{n}$ & $\%$ \\
\hline $\begin{array}{l}\text { Provavelmente ela conseguirá ingressar no curso desejado se realmente se esforçar, ainda que } \\
\text { não seja fácil. }\end{array}$ & 44 & 83 & 33 & 62,3 \\
\hline $\begin{array}{l}\text { Não importa o esforço que ela faça, dificilmente ela terá chances de ingressar em cursos muito } \\
\text { concorridos }\end{array}$ & 2 & 3,8 & 3 & 5,7 \\
\hline $\begin{array}{l}\text { Talvez ela até consiga ingressar em alguma universidade, mas apenas nos cursos onde a } \\
\text { concorrência é baixa. }\end{array}$ & - & - & 9 & 17 \\
\hline Depende da capacidade da pessoa. & 7 & 13,2 & 8 & 15,1 \\
\hline Não sei. & - & - & - & - \\
\hline Sem Resposta & - & - & 1 & \\
\hline TOTAL & 53 & 100 & 54 & 100 \\
\hline
\end{tabular}

Dos participantes do GA, $44(83 \%)$ responderam que provavelmente o mesmo conseguiria ingressar no curso desejado caso se esforçasse; e sete deles (13\%) afirmam que dependerá da capacidade da pessoa. Novamente observam-se crenças elevadas de auto-eficácia e expectativas positivas de resultados na escolha da opção educacional e de carreira, porém focalizam-se mais os inputs pessoais desprivilegiando os fatores contextuais. Assim, observa-se a ideologia neoliberal presente nos discursos de alguns participantes As categorias de resposta "dificilmente terá chances" e "apenas em cursos onde a concorrência é baixa" foram agrupadas para que pudessem ser tratadas estatisticamente $\left(\mathrm{X}^{2}\right)$, somando no grupo A 3,8\% $(\mathrm{n}=2)$. Já no Grupo B, 33 dos participantes $(62 \%)$ afirmam que o estudante conseguiria ingressar caso se esforçasse; oito deles (15\%) acreditam que 
dependerá da capacidade deste vestibulando; e 22,7\% $(\mathrm{n}=12)$ correspondem às categorias “dificilmente" e "onde a concorrência é menor" agrupadas.

Comparando-se os grupos A e B conclui-se que na categoria de resposta "provavelmente o mesmo conseguiria ingressar no curso desejado se realmente se esforçasse", percentual dos comunitários é significativamente superior ao percentual dos particulares $(83,0 \% \mathrm{X} 62,3 \%)$. Nas categorias agrupadas (“dificilmente terá chances” e "apenas em cursos onde a concorrência é baixa”) o percentual de estudantes dos cursinhos comunitários é significativamente inferior ao percentual dos particulares $(3,8 \%$ X $22,7 \%)$, o que pode ser entendido aqui como influencia da ideologia dominante neoliberal de que todos podem alcançar o sucesso desde que se esforcem, ignorando ou omitindo as desigualdades educacionais, culturais, sociais e econômicas que influenciam as possibilidades de competição entre determinados grupos sociais pela ascensão educacional e social. Mais uma vez os fatores contextuais são desconsiderados para avaliar as possibilidades de efetivação da escolha do curso universitário, ou seja, passar no vestibular. Pode-se também associar as crenças dos estudantes do GA, mais otimistas quanto o sucesso no vestibular atrelado mais ao esforço individual, ao momento de vida em que buscam em si mesmos a força necessária para encarar esse desafio. Nesses casos os inputs pessoais são privilegiados na perspectiva da maior parte dos participantes. Além disso, há um diferencial entre os grupos que deve ser considerado: no GB a maioria já passou pela dura experiência de fracasso no vestibular (93\%), o que pode ter influenciado as percepções dos jovens, tornado-os mais realistas ou mais cientes sobre o tipo de seleção realizada pelo exame.

Em síntese, de acordo com o grupo A, o vestibular é um método justo (68\%); ao mesmo tempo em que os participantes afirmam que é injusto e que deveria ser modificado (62,3\%), apesar de discordarem que o mesmo deva ser extinto (75,4\%). Para esse grupo, mérito e esforços individuais são suficientes para garantir o sucesso $(77,3 \%)$ ao mesmo tempo em que admitem a influência da variável socioeconômica, visto que os ricos possuem mais chances de sucesso no vestibular $(71,7 \%)$. Observa-se, portanto, ambivalência no julgamento sobre o vestibular, que devem ser exploradas com 
a finalidade de investigação da perspectiva desses jovens sobre a realidade presente em que vivem. De acordo com a Teoria das Representações Sociais, essa ambivalência parece estar ancorada em valores que fazem parte do universo consensual dos vestibulandos. O fato de que a grande maioria dos participantes do Grupo A não ter prestado anteriormente qualquer exame vestibular permite inferir que a opinião deles tem base em experiências vicariantes ou aprendizagem por observação, que apesar de se tratar de uma das fontes genuínas de auto-eficácia, são passíveis de idealizações sobre o processo seletivo em questão. Inclusive pelo fato de que, nos cursinhos comunitários como foi observado no Fórum de Cursinhos, enfatizam-se apenas experiências de sucesso de ex-alunos desses cursos em palestras e auto-relatos.

Em relação ao Grupo B, discordam que o vestibular seja um método justo $(75,9 \%)$, admitem que os estudantes ricos possuem mais chances $(90,7 \%)$ e acreditam que o vestibular deveria ser modificado $(77,4 \%)$, mas não extinto $(58,8 \%)$. A garantia do ingresso em uma universidade depende, para quase metade dos participantes $(46,3 \%)$ de motivações internas (como o mérito e o esforço individuais), enquanto as demais podem ser atribuídas a elementos contextuais, do meio externo. Cabe a ressalva de que desses estudantes, mais da metade (60\%) já prestou vestibular, tendo, portanto, já passado por essa experiência. Assim, a atitude mais negativa frente ao exame se justifica em parte por essa vivência passada que contribuiu para uma perspectiva mais realista da seleção, que considera outros fatores que não apenas os internos (motivação, esforço, capacidade individual), como por exemplo, questões macroestruturais nas quais se insere o modelo tradicional de vestibular. Quando as expectativas de resultado consideram os fatores contextuais elas se tornam mais realistas. Além disso, é possível considerar a introjeção, nesses jovens, de um sentimento negativo ou crenças negativas de auto-eficácia, decorrentes do fracasso anterior no exame. Outro aspecto a ser considerado nesse grupo (GB) é o fato dos participantes estarem mais inseridos no universo do vestibular e das carreiras acadêmicas, uma vez que em todos os cursinhos particulares havia serviço de Orientação Vocacional e Profissional. Esses serviços funcionam como suporte a dúvidas e 
incertezas dos vestibulandos frente à escolha de carreira, aos meios de acesso, dificuldades e modificações pertinentes ao mercado de trabalho, entre outros, como foi apontado pelos Coordenadores dos cursos.

\subsubsection{Tipo de cursinho e cotas universitárias}

Na questão 17.1 inquire-se diretamente sobre o posicionamento com respeito a "cotas para alunos egresso de escola pública, especialmente para negros e indígenas". As categorias "não tem informação a respeito" e "não sei” foram agrupadas para que pudessem ser tratadas estatisticamente. Como $\mathrm{X}^{2}=30,62$ e $\mathrm{p}<0,001$, conclui-se que a diferença entre os grupos A e B é significativa: o percentual de estudantes dos cursos comunitários (GA) que concordam é significativamente superior ao percentual dos estudantes dos cursos particulares (54,7\% contra $14,8 \%$ ), como era esperado. O GB discorda $(81,5 \%)$ de tais medidas, também como se esperava. Nesta questão cada grupo respondeu de acordo com o que considera mais vantajoso para os interesses do grupo de pertença (A ou B).

Na questão 17.2, busca-se investigar qual seria na opinião dos participantes o melhor critério para a medida de cotas, se “(a) só para negros e índios, (b) só para alunos de escolas públicas, (c) para negros, índios e alunos de escola pública, e (d) não deveriam existir cotas para nenhum grupo”.

Tabela 22. Opiniões de acordo com o tipo de cursinho sobre os critérios que poderiam ser melhor utilizados por Programas de Cotas Universitárias. Sendo: $\mathrm{X}^{2}=18,43$ e $\mathrm{p}<0,001^{*}$

\begin{tabular}{|c|c|c|c|c|}
\hline & \multicolumn{4}{|c|}{ Cursinho } \\
\hline & \multicolumn{2}{|c|}{ Grupo A } & \multicolumn{2}{|c|}{ Grupo B } \\
\hline & $\bar{n}$ & $\%$ & $\bar{n}$ & $\%$ \\
\hline Só para Negros e Indígenas & 1 & 1,9 & 1 & 1,9 \\
\hline Só para alunos de escola pública & 20 & 37,7 & 22 & 41,5 \\
\hline Negros, Indígenas e alunos de escola pública & 20 & 37,7 & 3 & 5,7 \\
\hline Não deveria haver Cotas & 12 & 22,6 & 27 & 50,9 \\
\hline TOTAL & 53 & 100 & 53 & 100 \\
\hline
\end{tabular}

Nessa questão, a categoria de resposta "só negros e índios" foi excluída por sua pouca representatividade. Nessa questão, há diferença significativa determinada pelo tipo de cursinho em 
duas categorias de resposta: “cotas para negros, indígenas e alunos de escola pública”, em que o percentual do GA é superior ao do GB (respectivamente 37,7\% e 5,7\%), e "não deveria haver cotas", de modo que o percentual de GA é menor que GB (22,6\% e 50,9\% respectivamente), como mostra a Tabela 22. Ou seja, o GA aceita melhor os critérios intercalados do que o GB, que por sua vez prefere que não haja cotas ou medidas alternativas no vestibular. Respondeu "cotas só para alunos de escola pública" $37,7 \%$ do grupo A, e 41,5\% do B. Esse dado é interessante, pois ainda que os estudantes de cursinhos particulares possam ficar em situação de desvantagem com tal medida eles são mais favoráveis à política de ação afirmativa desde que destinadas aos alunos provenientes de escolas públicas. Sobre se as cotas deveriam ser para os três grupos populacionais (alunos de escola pública, negros e indígenas) o percentual do Grupo A foi significativamente superior ao do Grupo B (37,7\% X 5,7\%). Deve-se lembrar que é esse o critério incentivado pelo governo federal, isto é, um critério que faça o cruzamento de variáveis entendidas como fundamentais para a inclusão no ensino superior: classe social, cor e, ou etnia. Os dados revelam que, de acordo com ambos os grupos, o melhor critério a ser adotado deveria ser apenas para os egressos de escola pública.

Ainda com relação à Tabela 22, na categoria de resposta "não deveriam existir cotas", também houve diferença significativa: o percentual do Grupo B que concorda com essa afirmação é significativamente superior ao do GA (50,9\% versus 22,6\%). Quanto a esse aspecto, pode-se entender que o Grupo B não apóie as cotas pelo fato de que essas medidas não os favoreçam ou que haja outros motivos envolvidos que devem ser investigados. Tal posição contradiz o discurso politicamente correto expresso na opinião de que as cotas universitárias deveriam ser apenas para alunos de escolas públicas. As contradições expressas nas opiniões evidenciam o quanto o assunto é polêmico e exige mais estudos inclusive de acompanhamento e avaliação das medidas.

Na afirmação de que "Políticas de cotas são uma boa forma de corrigir desigualdades raciais" (questão 18a), como mostra a Tabela 23, há diferença significativa $\left(X^{2}=31,02\right.$ e $\left.p<0,001 *\right)$ entre os 
grupos A e B, sendo que o percentual dos comunitários que concordam é significativamente superior ao dos cursinhos particulares.

Tabela 23 - Distribuição das respostas dadas às afirmações referentes à temática: cotas universitárias, por modalidade de cursinho comunitário (Grupo A) ou curso particular (Grupo B).

\begin{tabular}{|c|c|c|c|c|c|c|c|c|c|}
\hline \multirow{3}{*}{ Itens } & \multicolumn{4}{|c|}{ GRUPO A } & \multicolumn{4}{|c|}{ GRUPO B } & \multirow{3}{*}{$\begin{array}{l}\text { Qui- } \\
\text { Quadrado }\end{array}$} \\
\hline & \multicolumn{2}{|c|}{ concorda } & \multicolumn{2}{|c|}{ discorda } & \multicolumn{2}{|c|}{ concorda } & \multicolumn{2}{|c|}{ discorda } & \\
\hline & $\mathrm{n}$ & $\%$ & $\mathrm{n}$ & $\%$ & $\mathrm{n}$ & $\%$ & $n$ & $\%$ & \\
\hline $\begin{array}{l}\text { (18a) Políticas de cotas raciais são uma boa forma de } \\
\text { corrigir desigualdades raciais históricas. }\end{array}$ & 25 & 47,2 & 28 & 52,8 & 3 & 5,6 & 51 & 94,4 & $\begin{array}{l}X^{2}=1,02 \\
p<0,001^{*}\end{array}$ \\
\hline $\begin{array}{l}\text { (18b) Políticas de cotas raciais deveriam ser adotadas junto } \\
\text { com um maior investimento na educação básica }\end{array}$ & 39 & 73,6 & 14 & 26,4 & 27 & 50,9 & 26 & 49 & $\begin{array}{l}X^{2}=6,31 \\
p=0,04^{*}\end{array}$ \\
\hline (18c) Melhor seria investir na educação básica. & 48 & 90,6 & 5 & 9,4 & 54 & 100 & - & - & $p=0,03^{*}$ \\
\hline $\begin{array}{l}\text { (18d) As pessoas deveriam entrar na universidade somente } \\
\text { por seus méritos e esforços próprios. }\end{array}$ & 42 & 82,3 & 9 & 17,6 & 39 & 72,2 & 15 & 27,8 & $\begin{array}{l}X^{2}=3,43 \\
p=0,14\end{array}$ \\
\hline $\begin{array}{l}\text { (18f) As pessoas não deveriam entrar numa universidade } \\
\text { favorecidos por uma lei como a reserva de vagas. }\end{array}$ & 23 & 43,4 & 30 & 56,6 & 42 & 77,8 & 12 & 22,3 & $\begin{array}{l}X^{2}=19,31 \\
p<0,008^{*}\end{array}$ \\
\hline
\end{tabular}

(*) diferença significativa

Há ambivalência no grupo dos comunitários, sendo que quase a metade dos participantes desse grupo (47,2\%) concorda ou concordam fortemente com a afirmação. O fato das respostas mais assinaladas corresponderem às categorias "concordo" e "discordo" confirma essa ambivalência. Pode-se inferir que sobre essa questão 17.2 a opinião dividiu-se em ambos os grupos. Parece não haver consenso nem quanto ao fato de medidas como as cotas serem uma boa maneira de corrigir desigualdades, nem quanto ao melhor critério a ser adotado. Tais ambivalências expressas nas opiniões evidenciam, uma vez mais, o quanto o assunto é polêmico.

No grupo dos particulares, porém, há maior convicção de discordância, sendo que 94,4\% discordam ou discordam fortemente contra apenas 5,6\% dos que concordam ou concordam fortemente.

Sobre se "as políticas de cotas deveriam ser acompanhadas por investimentos em educação básica" (questão 18b), estatisticamente o percentual dos participantes do Grupo A que concorda com afirmação é significativamente superior ao Grupo $B\left(\mathrm{X}^{2}=6,31\right.$ e $\left.\mathrm{p}=0,04 *\right)$, como mostra a Tabela 23. Isto é, no Grupo A houve relativo consenso, sendo que $73,6 \%$ concordam. Já no Grupo B identifica-se ambivalência: 50,9\% concordaram e 49\% discordaram. Na questão $18 \mathrm{c}$ "melhor seria 
investir em educação básica", não houve diferença significativa entre os tipos de cursinhos $\left(\mathrm{X}^{2}=3,43\right.$ e $\mathrm{p}=0,14$ ) é a alternativa mais votada pelos participantes dos grupos A e B, respectivamente com $90,6 \%$ e $100 \%$ das respostas.

Há, portanto, consenso entre os participantes sobre a educação básica brasileira, que precisa ser revista. Esse tipo de discurso ancora-se em uma discussão histórica no cenário brasileiro acerca desse nível de ensino que apesar de aparecerem como a principal causa do despreparo para etapas posteriores de ensino, parecem também assumir um caráter ideológico que não só legitima a discriminação social no ensino superior como também justifica a perversidade de mecanismos remanescentes de manutenção desse status quo social, como os vestibulares tradicionais, vinculados a universidades públicas. É no sentido de interferir sobre esse processo que políticas de ação afirmativa são propostas. Trata-se de um mecanismo de discriminação positiva com finalidade a intervenção, em curto prazo, na realidade educacional brasileira que é educacional e socialmente injusta.

Em relação à entrada na universidade há dois enunciados. Na afirmação "As pessoas deveriam entra na universidade somente por seus méritos e esforços próprios” (questão 18d), os participantes de ambos os grupos concebem que atitudes individuais como esforço e mérito deveriam ser suficientes para o sucesso no vestibular, de modo que concordam $82,3 \%$ no Grupo A e $72,2 \%$ no Grupo B. Sobre o beneficio das cotas, na questão 18f: “as pessoas não deveriam entra numa universidade favorecidas por uma lei como a reserva de vagas", verificou-se que o percentual de respostas do Grupo B, que concordam fortemente é significativamente superior ao do Grupo A (42,6\% X 9,4\%), como evidencia a Tabela 23.

Na questão 19, pergunta-se se os estudantes "concordam com o Projeto de Lei Federal 3627/04 que concede reserva de vagas (cotas) para estudantes que tenham cursado o ensino médio em escola pública e, em especial para negros e indígenas, em instituições federais de educação superior”, verificou-se que há diferença significativa entre os grupos $\mathrm{A}$ e $\mathrm{B}\left(\mathrm{X}^{2}=32,873\right.$ e p $\left.<0,001\right)$, de modo 
que o percentual dos comunitários (GA) que responderam "sim" é significativamente superior ao percentual dos particulares (GB) (64,2\% versus $14,8 \%)$, o que era esperado.

$\mathrm{Na}$ questão 17, pergunta-se se os participantes sabiam da existência de pelo menos 14 instituições brasileiras de ensino superior (número oficial na época da recolha de dados, atualmente se fala em 43 instituições) que adotam programas de reserva de vagas para alunos de escolas públicas, afrodescendentes e populações indígenas. Em relação aos grupos, de acordo com $X^{2}=3,45$ e p = 0,06; pode-se afirmar que apesar de não haver diferença estatística significativa, constata-se uma fortíssima tendência do GB apresentar percentual de conhecimento superior em relação ao GA (respectivamente 83,3\% e 67,9\%). Assim, o GB julga-se mais informado a respeito das cotas em funcionamento. Pode ajudar a compreender essa tendência o fato já mencionado de que os cursinhos privados dispõem de serviços de Orientação para o Vestibular e Orientação Profissional que disponibiliza recursos de suporte, auxílio sobre a escolha profissional e informações gerais sobre as carreiras universitárias, fornecendo também dados de realidades, informações sobre o mundo do trabalho. Tal orientação especializada não se encontra disponível aos estudantes do Grupo A.

Em síntese, a respeito do tema cotas universitárias, observou-se que no GA a opinião dos vestibulandos sobre os programas de cotas divide-se. Um pouco mais da metade concorda com as cotas para egressos de escola pública, em especial para negros e indígenas e cotas apenas para egresso de escola pública. Já o Grupo B há maior consenso ao responderem que não deveriam existir cotas $(85,2 \%)$. Esse dado pode confirmar a tendência do GB de defender os próprios interesses. Ou seja, estudantes dos cursinhos particulares não se beneficiarão com os programas de cotas, portanto, são contrários a esse tipo de seleção que levará em consideração outros critérios que não apenas o mérito. Inversamente, vestibulandos de cursinhos comunitários apóiam em sua maioria a adoção desses modelos para flexibilizar o acesso de estudantes desfavorecidos pelo modelo atual de seleção para o ensino superior. Deve-se considerar o potencial ameaçador sugerido pela representação das cotas entre os que não se beneficiariam delas, visto que as vagas existentes que já eram bastante 
concorridas e com as ações de inclusão de estudantes cotistas acredita-se que concorrência aumentará.

Os alunos cotistas, com um perfil que até então não ameaçava a hegemonia branca e elitista, ao exigirem um espaço no nível superior de ensino passam a incomodar aqueles que defendem a manutenção do status quo. Por outro lado, torna-se necessário repensar a universidade e sua função na contemporaneidade com vistas à democratização do acesso ao conhecimento e ao poder.

\subsubsection{Tipo de cursinho e Medidas Governamentais de acesso ao Ensino Superior}

As questões 13A, 13B, 13C, 13D e 15C averiguam a opinião dos participantes sobre as medidas governamentais a respeito da inclusão ou da promoção de igualdade de oportunidades no acesso ao ensino superior (Tabela 24). Na questão se "todas as pessoas, independente de sua cor e, ou raça, deveriam ser tratadas da mesma forma e possuir os mesmos direitos" (13a) a resposta foi unânime: todos os participantes concordam ou concordam fortemente. Sobre o papel do governo na garantia dos direitos, em 13b afirma-se que "não é função do governo garantir esses direitos", discordam dessa afirmação $68,1 \%$ do GA e $77.7 \%$ do GB. Em contrapartida, na questão 13 c “o governo deve fazer tudo que puder para melhorar as condições sociais e econômicas dos negros", concordam ou concordam fortemente $79,3 \%$ do GA e $77,7 \%$ do GB.

Tabela 24 - Distribuição das respostas dadas às afirmações referentes à temática Medidas Governamentais de acesso ao Ensino Superior, por modalidade de cursinho comunitário (Grupo A) ou curso particular (Grupo B).

\begin{tabular}{|c|c|c|c|c|c|c|c|c|c|}
\hline & \multicolumn{4}{|c|}{ GRUPO A } & \multicolumn{4}{|c|}{ GRUPO B } & \multirow{3}{*}{$\begin{array}{c}\text { Qui- } \\
\text { Quadrado }\end{array}$} \\
\hline & \multicolumn{2}{|c|}{ concorda } & \multicolumn{2}{|c|}{ discorda } & \multicolumn{2}{|c|}{ concorda } & \multicolumn{2}{|c|}{ discorda } & \\
\hline & $\mathrm{n}$ & $\%$ & $\mathrm{n}$ & $\%$ & $\mathrm{n}$ & $\%$ & $n$ & $\%$ & \\
\hline $\begin{array}{l}\text { (13a) Todas as pessoas, independente de sua } \\
\text { cor/raça, deveriam ser tratadas da mesma forma e } \\
\text { possuir os mesmos direitos. }\end{array}$ & 53 & 100 & - & - & 54 & 100 & - & - & $p=0,06\left({ }^{* *}\right)$ \\
\hline $\begin{array}{c}\text { (13b) Todas as pessoas, independente de sua } \\
\text { cor/raça, deveriam ser tratadas da mesma forma e } \\
\text { possuir os mesmos direitos. }\end{array}$ & 27 & 51,9 & 25 & 48,1 & 12 & 22,3 & 42 & 77,7 & $\begin{array}{l}X^{2}=11,52 \\
p=0,009^{*}\end{array}$ \\
\hline $\begin{array}{l}\text { (13c) O governo federal deve fazer de tudo que puder } \\
\text { para melhorar as condições sociais e econômicas dos } \\
\text { negros }\end{array}$ & 42 & 79,3 & 11 & 20,7 & 42 & 77,7 & 12 & 22,3 & $\begin{array}{c}X^{2}=6,54 \\
p=0,09\end{array}$ \\
\hline $\begin{array}{c}\text { (13d) O governo não deve fazer nenhum esforço } \\
\text { especial para ajudar os negros porque eles mesmos } \\
\text { devem se ajudar }\end{array}$ & 12 & 22,6 & 41 & 77,3 & 2 & 3,7 & 52 & 96,3 & $\begin{array}{l}X^{2}=14,87 \\
p=0,001^{*}\end{array}$ \\
\hline
\end{tabular}


(15c) Japoneses, alemães, italianos e outros imigrantes superaram as dificuldades e progrediram

socialmente no Brasil. Os negros deveriam fazer

mesmo sem precisar de nenhum favor por parte do

Estado ou da sociedade.

(*) diferença significativa

(**) tendência à diferença significativa

Ainda sobre a intervenção governamental, nas respostas a questão 13d "o governo não deve fazer nenhum esforço especial para ajudar os negros porque eles mesmos devem se ajudar" prevalecem os que discordam, o correspondente a $77,3 \%$ do GA e $96,3 \%$ do GB. "Japoneses, alemães, italianos e outros imigrantes superaram as dificuldades e progrediram socialmente no Brasil.

Os negros deveriam fazer o mesmo sem precisar de nenhum favor por parte do Estado ou da sociedade" (questão 15c). A resposta "concordam" ou "concordam fortemente" foi ambivalente no GA (45,3\%). Já no GB sobressaiu-se a resposta "discordo" ou "discordo fortemente" representando $66,7 \%$ de $\mathrm{B}(\mathrm{n}=36)$.

Conclui-se, portanto, que ambos os grupos são unânimes ao sustentarem que todos devem ser tratados indistintamente e possuir os mesmos direitos. O grupo A acredita que é papel do governo garantir direitos e igualdade de oportunidades entre todos (caráter universal). Acredita-se também que é do governo o papel de regularizar a situação para os negros, tidos como grupos em desvantagem, devendo fazer todos os esforços para que a igualdade ocorra (medida diferencial para garantia e, ou conquista de igualdade). Houve, porém, ambivalência na medida em que quase metade do Grupo A concordou com o fato de que os negros deveriam eles mesmos se ajudar sem precisar de "favor do Estado", como fizeram outras etnias. Nessa questão, fica evidente a tentativa de descontextualização do processo civilizatório peculiar do negro no Brasil.

Assim, observa-se uma interessante dinâmica no grupo A, quando questionada a intervenção do governo na garantia desses direitos a populações específicas, no caso os negros. Quando comparados com outras etnias com outro histórico imigratório (japoneses e alemães, por exemplo.) nota-se claramente que o grupo dos comunitários (GA) tende a culpabilizar os grupos de pessoas em 
desvantagem pela própria exclusão, descontextualizando tal processo e desconsiderando influências do modelo de capitalismo neoliberal, de competição, que privilegia grupos detentores de capital econômico e cultural. De acordo com o grupo B, o governo tem um papel fundamental na promoção de políticas de igualdade $(77,7 \%)$ e no controle da discriminação racial sobre as oportunidades em geral (96,3\%), além do que não culpabilizam a etnia negra pela situação atual de discriminação, não descontextualizando o caso específico dos negros ao compará-los com outras etnias (66,7\%). Portanto, pode-se denotar que as opiniões de B apresentaram-se bastante concordantes quanto à atuação do governo na garantia dos direitos civis dos cidadãos.

\subsubsection{Tipo de cursinho e Questão Racial}

As seguintes afirmações referem-se ao conteúdo étnico-racial das questões: 12c, 14, 15a, 15b, 15d, 15e, 15f, 15g, 15h e 15i. Na questão 12c afirma-se que "estudantes brancos têm mais chances de entrar em uma boa universidade do que estudantes negros". A essa questão os resultados mostram que não houve diferença significativa entre os grupos $\mathrm{A}$ e $\mathrm{B}\left(\mathrm{X}^{2}=0,27, \mathrm{p}=0,88\right)$, de modo que concordam ou concordam fortemente 70,7\% integrantes do GA; e 67\% do GB, como mostra a Tabela 25.

Tabela 25 - Distribuição das respostas dadas às afirmações referentes à temática Questão Étnica e Racial, por modalidade de cursinho comunitário (Grupo A) ou curso particular (Grupo B).

\begin{tabular}{|c|c|c|c|c|c|c|c|c|c|}
\hline & \multicolumn{4}{|c|}{ GRUPO A } & \multicolumn{4}{|c|}{ GRUPO B } & \multirow{3}{*}{$\begin{array}{c}\text { Qui- } \\
\text { Quadrado }\end{array}$} \\
\hline & \multicolumn{2}{|c|}{ concorda } & \multicolumn{2}{|c|}{ discorda } & \multicolumn{2}{|c|}{ concorda } & \multicolumn{2}{|c|}{ discorda } & \\
\hline & $\mathrm{n}$ & $\%$ & $n$ & $\%$ & $\mathrm{n}$ & $\%$ & $n$ & $\%$ & \\
\hline $\begin{array}{l}\text { (12c) Estudantes ricos têm mais chance de entrar } \\
\text { numa boa universidade do que estudantes pobres. }\end{array}$ & 20 & 37,7 & 33 & 62,3 & 18 & 33,4 & 36 & 66,6 & $\begin{array}{l}X^{2}=0,27 \\
p=0,88\end{array}$ \\
\hline $\begin{array}{l}\text { (15a) Se pudessem comer bem e estudar numa boa } \\
\text { escola, os negros sempre teriam sucesso profissional. }\end{array}$ & 30 & 56,6 & 23 & 43,4 & 25 & 47,2 & 28 & 52,8 & $\begin{array}{l}X^{2}=7,53 \\
p=0,06^{* *}\end{array}$ \\
\hline $\begin{array}{c}\text { (15b) Toda raça tem gente competente e } \\
\text { incompetente, isso não depende da cor da pele. }\end{array}$ & 52 & 98,1 & 1 & 1,9 & 52 & 98,1 & 1 & 1,9 & $\begin{array}{l}\text { Não há } \\
\text { análise }\end{array}$ \\
\hline $\begin{array}{l}\text { (15d) Empenho e esforço na vida oferecem pouca } \\
\text { garantia de sucesso para os negros }\end{array}$ & 15 & 28,3 & 38 & 71,7 & 14 & 25,9 & 40 & 74,1 & $\begin{array}{l}X^{2}=0,72 \\
p=0,70\end{array}$ \\
\hline $\begin{array}{c}\text { (15e) Anos de escravidão e discriminação criaram } \\
\text { condições que tornaram difíceis para os negros } \\
\text { conseguirem sair da pobreza. }\end{array}$ & 38 & 71,7 & 15 & 28,3 & 48 & 88,9 & 6 & 11,1 & $\begin{array}{l}X^{2}=6,08 \\
p=0,05^{*}\end{array}$ \\
\hline $\begin{array}{c}\text { (15f) Os negros não têm problemas relacionados a sua } \\
\text { cor. }\end{array}$ & 3 & 5,7 & 50 & 94,3 & 2 & 3,7 & 52 & 96,3 & $p=1,00\left(^{* *}\right)$ \\
\hline $\begin{array}{l}\text { (15g) Os problemas dos negros são iguais àqueles } \\
\text { enfrentados pela maioria da população pobre. }\end{array}$ & 29 & 55,7 & 23 & 44,3 & 34 & 63 & 20 & 37 & $\begin{array}{l}X^{2}=1,34 \\
p=0,72\end{array}$ \\
\hline $\begin{array}{c}\text { (15h) No Brasil, brancos e negros são tratados de } \\
\text { forma diferenciada. }\end{array}$ & 44 & 83 & 9 & 17 & 47 & 87 & 7 & 13 & $\begin{array}{l}X^{2}=1,11 \\
p=0,57\end{array}$ \\
\hline
\end{tabular}




1

1,9

53

98,1

$\left.p=0,622^{* *}\right)$

(*) diferença significativa

$(* *)$ tendência a diferença significativa

Na questão 15, discute-se a existência ou não da discriminação racial propriamente dita, associada a temas como o processo histórico e formação étnico-racial da população brasileira, competência e sucesso profissional. Nesse sentido, quanto à afirmação de que "se pudessem comer bem e estudar numa boa escola, os negros sempre teriam sucesso profissional" (15a), concordam ou concordam fortemente $56,6 \%$ do GA e $47,2 \%$ de GB (Tabela 25 ).

Na questão 15 b "toda raça tem gente competente e incompetente, isso não depende da cor da pele", concorda a maioria dos participantes dos dois grupos: $98,1 \%$ (GA) e $98 \%$ (GB), como mostra a Tabela 38. Na questão "empenho e esforço na vida oferecem pouca garantia de sucesso para os negros" (15d), prevalece em ambos os grupos a opinião dos que discordam, respectivamente 71,7\% (GA) e 74,1\% (GB). Quanto ao sexo, na mesma questão (15d), o percentual de mulheres que discordam fortemente da afirmação é significativamente superior ao percentual dos homens $(32,3 \% \mathrm{X}$ 11,9\%). Na questão 15e, "anos de escravidão e discriminação criaram condições que tornaram difíceis para os negros conseguirem sair da pobreza", concordam ou concordam fortemente $71,7 \%$ do GA e $88,9 \%$ do GB. Em $15 f$ "os negros não têm problemas relacionados a sua cor", a maioria absoluta dos participantes discorda ou discorda fortemente $94,3 \%$ no GA e $96,3 \%$ no GB.

$\mathrm{Na}$ questão $15 \mathrm{~g}$ “os problemas dos negros são iguais àqueles enfrentados pela maioria da população pobre", as opiniões divergem dentro de cada grupo, já que 55,7\% dos participantes do GA e $63 \%$ do GB concordam ou concordam fortemente. Estatisticamente não houve diferença significativa quanto ao tipo de cursinho $\left(\mathrm{X}^{2}=1,34\right.$ e $\left.\mathrm{p}=0,72\right)$. Na questão $15 \mathrm{~h}$, "no Brasil, brancos e negros são tratados de forma diferenciada", do total de participantes, $85,1 \%$ discordam ou discordam fortemente, sendo $83 \%$ no GA e $87 \%$ no GB. Não houve diferença significativa nem em relação ao tipo de cursinho. Analogamente, com relação às opiniões sobre se "não existe preconceito no Brasil, 
pois somos uma nação miscigenada e sem conflitos raciais" (questão 15i), a esmagadora maioria, 97\% dos participantes discorda da afirmação, sendo que no GA e no GB essa porcentagem corresponde respectivamente a $96,3 \%$ e $98,2 \%$. Não houve diferença significativa entre os tipos de cursinhos. Novamente os participantes, de ambos os grupos, desmistificam o mito da nação sem conflito racial.

A questão 14 traz no enunciado alguns dados sobre a discrepância entre salários de brancos e negros e sobre a concentração de negros entre os mais pobres no cenário brasileiro (Tabela 26). Pergunta-se sobre qual é o principal motivo que leva a população negra a viver em piores condições que a população branca. A resposta mais assinalada é a que sugere que essa condição se deve ao preconceito e a discriminação que existem contra negros, correspondendo a $60,7 \%$ do total de participantes, sendo $76,9 \%$ do GA e $46,3 \%$ do GB (Tabela 26).

Tabela 26. Freqüência de respostas dadas à questão 14, sobre o principal motivo associado à diferença entre os salários de negros e brancos no Brasil

\begin{tabular}{|c|c|c|c|c|c|c|}
\hline & \multicolumn{2}{|c|}{ GRUPO A } & \multicolumn{2}{|c|}{ GRUPO B } & \multicolumn{2}{|c|}{ TOTAL } \\
\hline & $\mathrm{n}$ & $\%$ & $\mathrm{n}$ & $\%$ & $\mathrm{n}$ & $\%$ \\
\hline O preconceito e a discriminação que existe contra negros. & 40 & 76,9 & 25 & 46,3 & 65 & 61,3 \\
\hline Os negros que não aproveitam as oportunidades que têm para melhorar de vida. & 1 & 1,9 & 1 & 1,9 & 2 & 1,9 \\
\hline A falta de mão-de-obra qualificada negra. & 1 & 1,9 & 8 & 14,8 & 9 & 8,5 \\
\hline Falta de políticas por parte do governo. & 3 & 5,8 & 5 & 9,3 & 8 & 7,5 \\
\hline Outra resposta. & 4 & 7,7 & 12 & 22,2 & 16 & 15,1 \\
\hline Não sei. & 3 & 5,8 & 3 & 5,6 & 6 & 5,7 \\
\hline
\end{tabular}

Como $\mathrm{X}^{2}=10,47$ e $\mathrm{p}=0,001^{*}$, pode-se afirmar que houve diferença significativa sendo que o percentual dos cursinhos comunitários (GA) que responderam que o principal motivo associado à diferença entre os salários de negros e brancos no Brasil deve-se ao "preconceito e a discriminação que existe contra negros" foi significativamente superior ao dos particulares (GB), respectivamente $76,9 \%$ e 46,3\%. No GB, as respostas "outros motivos" e "falta de negros qualificados" representaram respectivamente $22,2 \%$ e $14,8 \%$. Dentre os "outros motivos", destacam-se as respostas que relacionam tal desigualdade ao período da escravidão, ou seja, uma preocupação histórica com a situação vigente. Outro motivo mais mencionado pelos participantes foi o de que essa disparidade 
entre salários de se dá em função da exclusão social, já a maioria negra ainda se concentra nas periferias ou ingressa em cursos de pouco prestígio que os fariam ganhar menos que os brancos, isto é, parte-se de um ciclo que se retro-alimenta e mantém as relações de dominação entre as classes. As demais respostas foram pouco representativas.

Em resumo, sobre a temática questões étnico raciais, a variável modalidade de cursinho teve pouca influência sobre a opinião dos estudantes acerca das questões raciais trazidas no questionário. Nesse sentido, a questão étnico-racial atinge o imaginário coletivo que é compartilhado por ambos os grupos e está ancorado historicamente como "problema-invisível” e que agora, com a denúncia das políticas afirmativas o mesmo aparece reluzente, exigindo que se revitalizem novas concepções. Assim, há consenso entre os participantes em geral de que existe preconceito de cor no Brasil. No entanto, parecem não associar uma conseqüência direta desse preconceito a âmbitos específicos, como nas oportunidades de acesso ao ensino superior. Ou seja, quando a questão é abordada diretamente, quando é trazida para realidade mais concreta, a dinâmica dos grupos se altera: em A se inverte, pois a grande maioria (quase $80 \%$ ) atribui a diferença de salários entre brancos e negros ao preconceito contra o negro. O Grupo B divide-se nessa afirmação. Ou seja, percebe-se que no âmbito teórico, ainda que seja consenso a existência de preconceito racial no Brasil, não se relaciona a esse preconceito restrição do acesso da população negra aos níveis de ensino mais elevados. Nesse sentido, cumpre salientar que os participantes assimilam melhor os problemas sociais do que os diretamente ligados a preconceitos raciais: são praticamente unânimes ao admitirem a existência de preconceito de cor, não havendo, no entanto consenso sobre de que maneira o problema da discriminação racial deva ser enfrentado. Nota-se que tanto na referida amostra como na sociedade em geral, uma forma encontrada de resolver esse impasse é utilizar uma estratégia que camufle o problema racial sob outro ainda mais intangível, assumindo-o como questão social. Isso permite que cada um não se sinta responsável pelo problema da discriminação racial, sob o argumento que a discriminação é fruto do modelo de funcionamento macroestrutural da sociedade, havendo, portanto, 
pouco ou nada que possa ser feito para alterar essa condição de desigualdade entre negros e brancos. Na medida em que a resolução de questões raciais seja diluída por outras (como problemas sociais, por exemplo), pode-se pensar nessa estratégia como ideológica, visto que a mesma dificulta a superação ou resolução de problemáticas especificamente raciais, de modo a manter o estado natural de exclusão, agora legitimado e engessado no funcionamento da sociedade como um todo.

Desse modo, pode-se inferir que a atitude frente à questão racial no Brasil ancora-se no universo consensual que evita o enfrentamento direto, contornando-o como se fosse um problema social. Os desdobramentos desse tipo pensamento perpetuam laços incontestáveis de dominação, sendo desfavoráveis à aceitação de políticas diferenciais para negros ou outros grupos com histórico de discriminação e encontram eco no universo reificado das ciências biológicas e suas descobertas genômicas que comprovam que não há diferenças gênicas significativas entre as etnias. Assim, o uso de um argumento científico-biológico acaba por inviabilizar a discussão, dando o assunto por encerrado. No entanto, outros saberes constituem também universos reificados com base nas ciências humanas que enfatizam o poder simbólico da discriminação que se omite no discurso, mas se entranha em aviltantes condutas discriminatórias.

\subsection{Comentários dos participantes sobre o Questionário COTAS}

A opinião sobre o questionário foi favorável na maioria das avaliações, de modo que 64,1\% do GA $(n=34)$ e $57,4 \%$ do GB $(n=31)$ responderam "bom"; $32,1 \%$ do GA $(n=17)$ e $29,6 \%$ do GB $(n=16)$ responderam "muito bom"; $3,8 \%$ do GA $(n=2)$ e $11,1 \%$ do GB $(n=6)$ avaliaram como "regular"; e apenas 1,9\% de GB (n=1) respondeu "muito fraco". Apresentou comentários 49,5\% dos questionários sendo 20 no GA e 33 no GB. Destacaram-se argumentos reafirmando que o problema em questão é social e não racial, que a universidade é ameaçada pelo risco de perder sua qualidade e excelência. Considerou-se um contra-senso buscar a universalidade a partir da diferenciação étnico- 
racial, que além de inconstitucional é vista como promotora de conflitos e arrefecimento das tensões raciais no Brasil. Um aspecto relevante apontado foi que as cotas são vistas como medidas paliativas para solução de problemas graves na educação básica das escolas públicas. Foi solicitado também que o assunto fosse mais divulgado. Sugeriu-se também que a questão das cotas deve ser debatida seriamente e melhor difundida nos meios de comunicação e mesmo nos cursinhos.

\subsection{Dados das Entrevistas}

Foram entrevistados seis participantes, sendo três do grupo A e três do Grupo B. As iniciais dos nomes fictícios indicam o grupo de pertença (Tabela 27).

Tabela 27. Quadro descritivo com algumas características dos entrevistados.

\begin{tabular}{lcccccc}
\hline & Ana & Alceu & Antônio & Bruna & Bianca & Breno \\
\hline GRUPO & A & A & A & B & B & B \\
\hline Idade & 17 & 18 & 18 & 19 & 18 & 18 \\
\hline EM & Público & Público & Público & Particular & Particular & Particular \\
\hline Autodenominação Étnico-Racial & Branca & Branca & Branca & Branca & Branca & Branca \\
\hline Já prestou Vestibular? & Não & Já & Não & Já & Já & Já \\
\hline $\begin{array}{l}\text { "O vestibular é um método justo" } \\
\text { (12A) }\end{array}$ & \multirow{2}{*}{ Concorda } & \multirow{2}{*}{ Concorda } & \multirow{2}{*}{ Concorda } & \multirow{2}{*}{ Discorda } & \multirow{2}{*}{ Concorda Discorda } \\
\hline
\end{tabular}

Os posicionamentos individuais mostraram-se bastante dicotômicos, no entanto todas as repostas dos seis entrevistados, ao serem reunidas, favoreceram uma visão mais integrada dos aspectos dialéticos pertinentes aos temas abordados. Assim, os conteúdos das entrevistas o serão apresentados na ordem dos seguintes subtítulos: Cotas Universitárias (prós e contras); e Trajetórias e Perspectivas. 


\subsubsection{Cotas Universitárias: prós e contras}

O primeiro eixo da entrevista foi referente às cotas universitárias. Perguntou-se sobre o que pensavam sobre o assunto, e a partir dos desdobramentos das respostas, eram aprofundados alguns dos argumentos utilizados por cada um. Com relação a esse eixo, quatro dos participantes referiramse, em um primeiro momento, apenas ao critério étnico-racial, denotando ser essa a característica mais associada à idéia de cotas. Breno e Bruna citaram também as cotas fundamentadas pelo critério social (para egressos do ensino médio público) como forma mais aceita do que a racial. Ana e Antônio posicionaram-se favoravelmente às cotas raciais, evidenciando ser uma forma de atuar diretamente sobre o racismo velado existente no Brasil.

"Acho que pode ser uma saída para agora. Todo mundo sabe que quase não tem negro nas universidades. Será que é só pelo fato de eles serem também a parte pobre? Não sei o que vem primeiro... às vezes só o fato de interferir nesse ciclo já seja um passo”.(Ana)

Observou-se que dentre os que não concordam com os sistemas de cotas (Breno, Bianca, Bruna e Alceu), há diferentes focos de preocupação suscitados pela intervenção das cotas. Os aspectos apontados como negativos foram referentes à defesa do Vestibular tradicional como incentivador do esforço individual avaliado mediante o desempenho dos candidatos. As cotas, ao intervirem diretamente sobre o vestibular e ao facilitar o acesso de determinados grupos sociais, terão repercussões negativas tanto para os não-beneficiados quanto para os cotistas, na visão dos participantes. De acordo com essa visão, aqueles por se prejudicarem pelo acirramento da disputa de vagas; e estes por não valorizarem essa oportunidade, já que foi conquistada com menos esforço, como mostram as falas a seguir.

"Cotas não deveriam existir. Por quê? Porque eu acho que uma pessoa deve entrar pela capacidade que ela deve ter. Porque uma coisa que venha fácil, que venha com facilidade, a gente não dá valor" (Alceu).

"Só que aí eu não consegui passar numa escola publica. Ai a gente acaba perdendo vaga para pessoas que estudaram... a gente acaba se prejudicando” (Bianca). 
Nesse sentido, os participantes disseram que a entrada de estudantes cotistas irá favorecer a queda de qualidade nesse nível de ensino e desestimular o empenho dos cotistas dentro das universidades, como demonstram as falas a seguir.

“A escola pública já está ruim, agora colocar aqueles alunos ruins para ir numa faculdade (pública), vai estragar o ensino na faculdade também. Eu acho que não é por aí não" (Alceu).

"Mas vamos supor, desses 50\% de escola publica que entrassem numa USP [retoma critério do projeto de Lei 3627/04]... Por exemplo, eu entrei na USP essa semana e é matéria, matemática forte, já... Eu acho que os de escola pública não seriam capazes de acompanhar, ter o mesmo aproveitamento dos de escola particular [...] Ou seja, a universidade poderia cair no seu rendimento” (Breno).

Tal constatação ancora-se nas representações sociais sobre o descrédito dados aos estudantes de escola pública e a precariedade dos ensinos fundamental e médio da rede pública de ensino. O investimento na melhoria desses níveis de ensino é unanimemente o foco mais ressaltado como alternativa às cotas para alterar o perfil elitista e branco dos universitários brasileiros, como apontado pelos participantes Antonio e Breno.

"Eu acho interessante poder dar oportunidades para as pessoas que tem dificuldade de estudar, mas só que também, às vezes essas pessoas com essa oportunidade podem ter vontade de não querer se esforçar mais" (Antonio).

"Acho que já rotula o negro como incapaz de encarar uma faculdade 'vamos dar uma ajudinha pro negro para ele entrar"” (Breno).

Salienta-se nesse trecho que as cotas são vistas como um "brinde" ou um "prêmio de consolação" pelo período de açoites e marginalizações sócio-cultural e econômico-político do negro no Brasil. Ainda com relação aos aspectos negativos, houve preocupação dos entrevistados sobre conseqüências do critério da autodenominação étnico-racial, como apontado nas falas a seguir. "Até porque todo mundo não fala que o Brasil é miscigenado? Então como se diferencia um índio de um negro? Todo mundo tem o mesmo tipo de sangue" (Bruna) / "Não concordo, assim, em diferenciar o ser humano em raças. Raça é humana” (Breno).

Coloca-se também em questão sobre quem deve assumir a responsabilidade pelos prejuízos 
históricos do período de escravidão.

"Por um lado ela beneficia negros e indígenas, queira ou não, que antigamente já foram muito discriminados, marginalizados pela sociedade... e até hoje isso se reflete. "Só que, por um lado, também pode estar prejudicando pessoas, principalmente as pessoas da classe média, e eu me incluo nessa”. (Bianca).

Três entrevistados colocaram suas concepções pessoais diretamente sobre o vestibular (Ana, Alceu e Bruna). Ana refere-se negativamente ao exame, argumentando que o próprio exame vestibular desencoraja os estudantes e que o medo gerado pela situação do exame influencia o desempenho do candidato.

\begin{abstract}
"Acho que é uma prova muito cruel. A gente aprende a ter medo de vestibular antes mesmo de sonhar em fazer faculdade. Conheço muita gente com capacidade que, por medo, não encara o vestibular. Às vezes os primeiros colocados não vão ser os melhores alunos. Aí é que eu penso: 'será que só tem esse jeito de saber quem vai ser bom na faculdade?", (Ana).
\end{abstract}

Por sua vez, Bruna questiona também o critério de pontos na distinção de quem entra ou não no vestibular.

\begin{abstract}
'Injusto, muito injusto! Até porque é por 'zero vírgula alguma coisa' que uma pessoa não entra, e ela tá tão preparada quanto àquela que entrou por 'zero vírgula alguma coisa' a mais... e porque é um tipo de avaliação que num dia, se você não estiver bem psicologicamente naquele dia, tudo o que você estudou o ano inteiro não valeu para nada! E eu sou completamente contra" (Bruna).
\end{abstract}

Por outro lado, foram também citados aspectos positivos associados à criação de cotas. Argumentou-se que apesar de se tratar de uma medida emergencial bastante agressiva de inserção (étnico-racial e social), acredita-se que a mesma assim se justifique por ser uma tentativa de interferência direta sobre um dos espaços de propagação do preconceito racial, representado pelo ensino superior.

\footnotetext{
"Acho que pode ser uma saída para agora. Todo mundo sabe que quase não tem negro nas universidades. Será que é só pelo fato de eles serem também a parte pobre? Não sei o que vem primeiro... as vezes só fato de interferir nesse ciclo já seja um passo." (Ana).
} 
Desse modo, a interferência das cotas pode sugerir uma ação de inserção que não dependa apenas de iniciativas morosas governamentais: "Por um lado eu sou a favor. Porque eu vejo que se não fizer isso, não vai mudar nunca, porque o governo não vai mudar de lá de baixo. Eu sou meio pessimista quanto a isso..." (Bruna).

Ainda nesse eixo temático sobre as cotas, pediu-se ao entrevistado que o mesmo tentasse colocar-se no lugar daqueles que defendiam a posição inversa à sua própria, imaginando embasamentos para tais argumentos. Foi interessante a reação de todos os entrevistados nessa tarefa. Os seis participantes tiveram um momento prolongado de silêncio, e acabaram argumentando que não pensariam de outra forma, julgando seus pontos de vistas mais coerentes. Verifica-se nesse item a utilização de argumentos vivenciais ou experiências próximas (de amigos e conhecidos) sobre uma situação que supostamente tiveram a oportunidade de acompanhar e dessa forma assumirem um determinado tipo de postura.

\subsubsection{Trajetórias e Perspectivas}

O segundo eixo temático enfocou a trajetória da escolha por um curso universitário e expectativas sobre o futuro profissional, ou seja, objetivos do projeto de vida. Alguns dos entrevistados incluíram a experiência do cursinho nesse eixo. Apesar do reconhecimento comum quanto ao papel do ensino superior na formação de profissionais capacitados, houve diferenças entre as expectativas dos entrevistados do Grupo A e do Grupo B. Entre os entrevistados do Grupo A, o interesse por um curso universitário estava relacionado ao status social e a expectativas de melhoria de vida e ascensão social: "É uma chance que vai começar a mudar minha vida. É uma meta minha, que é vencer na vida... Por tudo que minha mãe passou, acho que vale a pena lutar por um sonho”. (Alceu). Conforme a TSCC observam-se elevadas expectativas de resultados. Trata-se da escolha dos objetivos desencadeados pelos interesses, conduzindo às ações, que por sua vez poderão resultar no desempenho alcançado, por meio do ingresso no curso universitário e, posteriormente, inserir-se no 
mercado de trabalho como aponta, também, a fala a seguir.

Já no Grupo B, cursar o ensino superior representa o pré-requisito para a inserção futura no mercado de trabalho: "Quem não tem uma universidade hoje, tá fora (...) A minha mãe não tem universidade, mas ela conseguiu entrar no mercado. Mas a partir da nossa idade, quem não tem universidade, é dificil de se inserir. (Breno). Breno e Antonio comentam sobre o papel social que a Universidade deve cumprir.

"Acho que durante a universidade eu vou tentar buscar fazer alguma coisa para a comunidade. [...] Porque é a sociedade que está pagando para a gente estudar lá. Então eu acho que a universidade deve dar alguma retribuição para a sociedade". (Breno)

"A pessoa que está na universidade é uma pessoa que tem bom conhecimento, e pra poder ajudar tanto a si mesmo quanto aos outros". (Antonio)

Por outro lado, observam-se também expectativas negativas de resultados. Antonio ressalta o obstáculo financeiro imposto sobre seu desejo de ingressar no ensino superior:

"[...] eu não tava pensando muito nisso. Tava pensando em arrumar um emprego pra poder ajudar minha mãe, porque é só ela que trabalha em casa. [...] Mas ai ela pediu pra eu fazer, que assim ajudaria mais. Eu pensei, e fui na opinião dela [...] Eu falava que isso ai era um luxo”.

Bruna acrescenta seu relato pessoal para justificar a substituição do interesse por Medicina para a carreira de Administração, ocasionada pelos fracassos sucessivos no vestibular:

"Eu prestava Medicina. Agora mudei para Administração.[...]. Como eu tomei muito pau no vestibular [risos] eu resolvi: meu, vou tentar Administração, sabe, é uma coisa que é muito mais próxima.Já cheguei muito próximo todas às vezes da Medicina, mas nunca passei. E pelo sentimento de frustração resolvi prestar outra coisa." (Bruna).

As variáveis contextuais podem servir também como barreiras percebidas dificultando ou inviabilizando o ingresso no curso universitário. O que leva o jovem a expressar expectativas de resultado negativas. Tais barreiras podem levar à desistência antes do vestibular, durante o curso universitário e / ou às diversas mudanças de curso. Se ocorrem algumas dessas situações os resultados 
de desempenho não serão alcançados. As barreiras podem ser objetivas ou subjetivas, o importante é que elas sejam percebidas pelas pessoas para que possam ser transformadas em processos de intervenção. 


\section{Considerações finais}

Em síntese, foi possível constatar o quão notável é a falta de informação consistente sobre o funcionamento efetivo de programas de Cotas Universitárias e as outras formas de acesso e permanência no ensino superior, o que justifica a implementação de medidas de disseminação de informações entre jovens e a comunidade como um todo.

Trata-se de um campo que aparece repleto de inseguranças, controvérsias e preocupações, visto que não há clareza, por exemplo, sobre os critérios específicos de seleção (autodenominação étnico-racial, social, etc), ou sobre outros programas de suporte atrelados às cotas (aulas de reforço, bolsas, acompanhamento de desempenho dos cotistas, etc). Houve, entre os vestibulandos participantes, pouca abertura para esclarecimentos de dúvidas sobre tais questões, de modo que a pesquisadora foi solicitada para essa tarefa apenas com dois dos entrevistados da $2^{\mathrm{a}}$ etapa.

Nesse sentido, pôde-se concluir que há algumas preocupações com relação a conseqüências negativas geradas pela implementação das cotas e que condizem com argumentos levantados pela literatura sobre o tema. É o caso do receio de que a introdução do modelo de democratização do ensino superior com base da reserva de vagas teria conseqüência direta sobre a queda na qualidade de ensino das universidades públicas, pois permitiria a entrada de estudantes despreparados (egressos da rede pública, por exemplo). Embora essa visão seja reforçada inclusive pelos resultados do ENEM 2006, que indicou um melhor desempenho dos estudantes egressos da rede particular, há dados recentes de pesquisas envolvendo o desempenho de estudantes cotistas em contextos que já se valem desse modelo de seleção e que têm revelado resultados surpreendentes. Como, por exemplo, a avaliação de desempenho dos cotistas da UFBA, em julho de 2006, indicou que o desempenho acadêmico dos cotistas durante o ano, que, em 56\% dos cursos de graduação, foi igual, ou melhor, ao dos não-cotistas. 
Outra preocupação é a de que as cotas permitem o ingresso fácil ao ensino superior. Ou seja, tende-se a contrapor Esforço versus Cotas, como se o sistema de cotas não exigisse, por parte do ingressante, qualquer esforço além da autodenominação ou trajetória no ensino público, o que não ocorre na maioria dos programas de maior repercussão nacional. Por exemplo, na UnB exige-se uma pontuação mínima a qual todos os candidatos ao vestibular - cotistas ou não - devem de atingir para serem classificados. Em 2006, esse critério deixou de fora 40\% dos candidatos do sistema universal e $56,8 \%$ dos cotistas. Ou seja, não basta autodenominação para garantir uma vaga no ensino superior, exige-se também uma pontuação determinada. Além disso, tem sido cada vez mais comum o suporte pedagógico e sócio-econômico com finalidade de amparar e permitir a permanência dos estudantes menos abastados no espaço acadêmico das universidades em que há sistema de cotas (UFBA, UNICAMP, UnB, etc.), no entanto esse tipo de informação ainda não faz parte do repertório dos estudantes sobre esse tema.

Outra temática bastante abordada foi com relação ao Vestibular. Nesse tipo de exame, o mérito aparece como cerne, das crenças de auto-eficácia que os aproximam dos vestibulares. Ou seja, o esforço e o mérito são variáveis que estão mais ao alcance do indivíduo do que as condições materiais, de modo que se pode compreender a ênfase dada pelo vestibulando à crença em variáveis auto-referentes com alternativa superar desafios macroestruturais. Assim, os estudantes apegam-se a crenças de auto-eficácia e a expectativas de resultados positivas como forma de lidar com dificuldades concretas ligadas ao vestibular, de modo que elas estejam ao seu alcance. Isso ocorre de maneira geral, mas entre os entrevistados que defendem o modelo tradicional de vestibular tal comportamento aparece de maneira mais evidente.

À luz do modelo sócio-cognitivo de desenvolvimento vocacional na transição da escola para o trabalho (VIEIRA \& COIMBRA, 2006) pode-se compreender tal atitude positiva frente ao vestibular como indícios das primeiras tarefas, as quais consistem no desenvolvimento de expectativas de resultados e de crenças de auto-eficácia. No entanto, as ambivalências sugeridas pelo confronto entre 
méritocracia do vestibular X elitização do Ensino Superior, nos discursos dos participantes, sinalizam idealizações de uma condição contraditória que deve ser investigada, a fim de se delinear estratégias de intervenção nas expectativas de resultado negativas. Apesar de importante para o sucesso individual, além da motivação interna, há que se considerar também o delineamento concreto e bem definido de estratégias para o sucesso. Ainda que a crença na meritocracia - critério bem aceito para a seleção do vestibular - seja compartilhada entre os estudantes, a mesma fica mais evidente no grupo de estudantes dos cursos alternativos, ou seja, o grupo menos favorecido pela competição meritocrática do vestibular. Ou seja, os participantes do Grupo A são estudantes com pouca experiência em vestibulares, e possivelmente em situação de desvantagens educacionais, de modo que muitos deles entraram em contato com esse universo das carreiras universitárias já nos cursos prévestibulares. Assim, é comum que se atribua a esses cursos um caráter que ultrapassa em muito suas limitações, já que se trata de uma preparação para o vestibular em curto prazo e que não inclui uma orientação profissional mais específica. Jovens inexperientes ou com pouco contato com a realidade do tipo de seleção que vão enfrentar, ingressam nos cursos preparatórios e o idealizam como uma solução "milagrosa" que irá sanar defasagens que podem ter permeado a sua formação escolar. São fundamentais outros tipos de preparação, como: a busca por informações sobre as próprias aptidões e habilidades, quais os meios de acesso às universidades, quais as carreiras e as universidades disponíveis, se há meios alternativos de custeio tanto do ensino quanto da estadia do estudante, como funcionam as moradias, os auxílios financeiros, as bolsas alimentação, etc. Existe uma série de questões que devem ser consideradas além da preparação e treino para as provas seletivas e da "vontade" de fazer faculdade. Por fim, o mito da "meritocracia democratizadora" dos exames vestibulares, que teoricamente colocam todos os candidatos em uma mesma situação-teste, deve ser desnaturalizado. Isso porque o preparo que antecipa o vestibular recebe influência direta de outras variáveis, como por exemplo, o capital cultural. O processo de desconstrução desse mito consistiria inicialmente na quebra do relativo "conforto onipotente" sugerido pelo controle individual sobre a 
entrada na universidade (ou seja, o esforço como garantia de sucesso), para então contribuir para a criação de estratégias de enfrentamento mais efetivas na democratização do ensino.

Quanto ao papel das ações do governo, deve-se considerar a responsabilidade do Estado sobre a iniqüidade das relações discriminatórias e marginalizantes do modelo atual de funcionamento da sociedade brasileira. O que agrava o problema é que, no caso do sistema dos vestibulares tradicionais, condições de desigualdade entre os candidatos tornam perniciosas as relações entre competição, mérito e auto-eficácia, que se retro-alimentam, mantêm a dinâmica das relações de dominação "darwinista" e atuam sobre a culpabilização do indivíduo por graves problemas estruturais de acesso à universidade. É nesse sentido que o universo reificado (UR), construído no âmbito das ciências humanas, devem contribuir para uma complementação da visão sobre todo o processo.

Outra preocupação refere-se ao mito da democracia racial, que se mantém como aspecto da identidade coletiva de cultura nacional. Acredita-se que a definição étnico-racial irá aumentar um conflito racial no país. A dessimbiotização étnico-racial, proposta por medidas de ação afirmativa, causa um grande conflito entre os brasileiros, habituados a se aceitarem como pretensos "tolerantes raciais". Nesse sentido, ações afirmativas forçam uma mudança de postura com relação às incoerências dessa identidade que se presenciam no cotidiano. Há consenso sobre a existência de um racismo coletivo, mas nega-se a participação individual nesse processo. Urge a necessidade de encarar essa ferida nacional, e as cotas universitárias incomodam o senso comum e forçam uma atitude indivíduo-sociedade mais efetiva de combate aos problemas raciais sedimentados na base do pensamento de valorização da multiracialidade brasileira. No entanto, não se trata de uma hipótese, mas de uma medida efetiva de intervenção em pleno funcionamento em diversas instituições de ensino superior e que deve ser acompanhada desde a sua implementação até seu término.

Por fim, observou-se que apesar da ampla expansão de programas de cotas no Brasil, tanto em Instituições de ensino superior de administração pública quanto privada, há a necessidade de regulação dessas medidas e acompanhamento de suas repercussões. Essa é uma tarefa que deve reunir 
esforços da sociedade civil, da comunidade acadêmica, juntamente com órgãos governamentais para suprir a escassez de estudos referentes à efetivação desses programas de modo a cumprirem um padrão mínimo de exigência, que abarquem a prestação de contas sobre os critérios de seleção e mecanismos de manutenção dos novos egressos e suas dificuldades especificas (recursos financeiros, aulas de reforço, etc); sobre os objetivos dos programas e suas repercussões micro e macro estruturais; sobre desempenho dos cotistas em relação aos demais; levantamento das dificuldades eventuais suscitadas com a adoção dessas medidas (discriminação étnico-racial ou social, estigmas associados ao cotista no espaço intra-universidade, etc) e espaço para construção de saberes e alternativas de solução subsidiárias.

Finalizando, cumpre destacar que diferentes práticas e linhas investigativas podem ser desenvolvidas neste domínio, em cenários e contextos diversificados, a saber: (1) políticas públicas de acesso e permanência na universidade, (2) avaliação dos programas de cotas universitárias, (3) comparação entre diferentes programas de cotas universitárias, (4) estudos longitudinais de grupos de alunos cotistas, com acompanhamento durante a universidade e depois no mercado de trabalho (5) propostas de programas de divulgação na mídia sobre as medidas alternativas de ingresso na universidade, (6) implantação, acompanhamento e avaliação de programas de intervenção em Informação e Orientação Profissional, sobretudo em escolas públicas, entre outras. Todas são linhas investigativas promissoras, atuais e necessárias. 


\section{Referência Bibliográfica}

ABERAStURY, A. et al. Adolescência. Porto Alegre, RS: Artes Médicas, 1983.

ARAÚJO U.C.; ARAÚJO, C.H. Desigualdade Racial e Desempenho Escolar. Brasília, DF. Set. 2003. Retirado em: 13/05/2005, no World Wide http://www.inep.gov.br/imprensa/artigos/araujo_ubiratan.htm

BANDURA, A. Social foundations of thought and action: A social cognitive theory. Englewood Cliffs, NJ: Prentice Hall, 1986.

BARDIN, L. Análise de Conteúdo. Lisboa, Edições 70, 1977.

BLEGER, J. Temas de Psicologia: entrevista e grupos. São Paulo, SP: Ed. Martins Fontes, 1998.

BOHOSLAVSKY, R. Orientação Vocacional: a Estratégia Clínica. São Paulo, SP. Martins Fontes, 1991.

BOLLINGER, L. C. The need for diversity in higher education. Academic Medicine, 78(5), 2003, 431-436.

BOURDIEU, P. Os três estados em Capital Cultural. In: NOGUEIRA, M. A.; CATNAI, A. (orgs) Escritos em Educação. Petrópolis, RJ: Vozes, 5ª edição, 2003.

BRASIL. Constituição da República Federativa do Brasil: promulgada em 05 de outubro de 1988. Retirado em: 12/01/2005, no World Wide http://www.planalto.gov.br/ccivil_03/Constituicao/Constituiçao.htm

BRASIL. Projeto de Lei $\mathrm{n}^{\mathrm{o}} 3627$, de agosto de 2005. Dispõe sobre o ingresso nas universidades federais e dá outras providências. Congresso Nacional, ago. 2005. Retirado em 23/09/2005, no World Wide Web: http://www.camara.gov.br/sileg/integras/330424.pdf

BRASIL. Lei $n^{\circ}$ 9.394, de 20 de dezembro de 1996. Estabelece as diretrizes e bases da educação nacional. Congresso Nacional. Brasília, DF, 20 dez. 1996;

BRITO, L. Melhor no Enem, Dom Barreto tem professores mestres e doutores. Portal de Notícias da Globo, 2007. Retirado em 06/07/2007, no World Wide Web: 
http://g1.globo.com/Noticias/Vestibular/0MUL4599-5604,00.html

CAVALLEIRO, E. Do silêncio do Lar ao silêncio Escolar: racismo. São Paulo, SP. Contexto, 2000.

DURHAM E.R . Desigualdade Educacional e Quotas para Negros nas Universidades. Equipe do Núcleo de Pesquisas sobre Ensino Superior (NUPES), Universidade de São Paulo. São Paulo, 2003a.

. O Ensino Superior no Brasil: público e privado. Equipe do Núcleo de Pesquisas sobre Ensino Superior (NUPES), Universidade de São Paulo. São Paulo, 2003 b.

FRY, P.; MAGGIE, Y. A Reserva de Vagas para Negros nas Universidades Brasileiras. Estudos Avançados, São Paulo, 18, (50), jan /abr, 2004, 67-80

GONÇALVES, L. A. O. ; SILVA, P. B. G. O Jogo das Diferenças: O multiculturalismo e seus contextos. Coleção Cultura Negra e Identidades. Belo Horizonte: Autêntica, 2006

GUARNIERI, F.V. ; MELO-SILVA, L. L. Ações Afirmativas na Educação Superior: Rumos da Discussão nos Últimos Cinco Anos. Revista Psicologia e Sociedade, Rio grande do Sul, 19 (1), 2007. (no prelo)

GUIMARÃES, A.S.A. A desigualdade que anula a desigualdade: Notas sobre a ação afirmativa no Brasil. In: SOUZA, J. (org) Multiculturalismo e racismo: uma comparação Brasil-Estados Unidos. Brasília, DF: Paralelo 15, 1997.

(coord). A Cor da Bahia: Programa de Pesquisa e Formação sobre Relações Raciais, Cultura e Identidade Negra na Bahia. Integrado ao Mestrado em Sociologia da UFBA, 1991. Retirado em 20/06/2005, no World Wide Web: http://ospiti.peacelink.it/zumbi/afro/corbahia.html\#obj

GRACIANO, M. I. G.; LEHFELD, N. A. S.; NEVES FILHO, A. Critério de Avaliação para Classificação Socioeconômica: Elementos de Atualização. Serviço Social \& Realidade. Franca, 8, (1), págs. 109-128, 1999.

HTUN, M. From "Racial Democracy" to "Affirmative Actions": Changing state policy on race in Brazil. Latin American Research Review, 39(1), 2004, 60-89.

IANNI, O. Enigmas da Modernidade-Mundo. Rio de Janeiro, RJ. Civilização Brasileira, 2000. 
IKWA, D; PIOVESAN, F; ALMEIDA, G; GOMES, V. Convenções Internacionais de Direitos Humanos. Curso de Formação de Conselheiros em Direitos Humanos, Abr-Jul, 2006. retirado em: 20/12/2007, no World Wide Web http://www.cultiva.org.br/pdf/modulo1_aula5.pdf

LENT, R.W., BROWN, S.D., \& HACKETT, G. Toward a unifying social cognitive theory of career and academic interest, choice, and performance. Journal of Vocational Behavior, 45, 1994, 79-122.

MENA, L. F. B. Inclusões e Inclusões: A Inclusão Simbólica. Psicología Ciencia e Profissão. Conselho Federal de Psicología, 20 (1), p. 30-39, 2000.

MENEZES, J. Ufba: pesquisa aponta desempenho superior dos estudantes cotistas. Assessoria de Comunicação e Imprensa da Unicamp. Clipping Unicamp. Jul, 2006. Retirado em 20/12/2007, no World Wide Web http://www.unicamp.br/unicamp/canal_aberto/clipping/julho2006/clipping060729_ FOLHADIRIGIDA.html

MINAYO, M. C. de S. O Desafio do Conhecimento: Pesquisa Qualitativa em Saúde. São Paulo: Hucitec/ Rio de Janeiro: Abrasco, 1992.

MINISTÉRIO DA EDUCAÇÃO (MEC). Informações sobre a educação no Brasil, programas e projetos, notícias, e links de interesse. Retirado em 13/12/2006, no World Wide Web: http://portal.mec.gov.br/index.php

MOEHLECKE, S. Fronteira da Igualdade no Ensino Superior: Excelência e Justiça Social. 2004. 179f. Tese de Doutorado em Educação. Universidade de São Paulo. São Paulo, 2004.

MORIN, E.; MOIGNE, J. L. A inteligência da complexidade. São Paulo: Petrópolis, 2000.

MUNANGA, K. A Difícil Tarefa de definir Quem é Negro no Brasil. Estudos Avançados. 18 (50), 2004a

Rediscutindo a Mestiçagem no Brasil: Identidade Nacional versus Identidade Negra. Belo Horizonte, BH. Ed. Autêntica. 2004b.

PEREIRA, C.; TORRES, A. R. R; ALMEIDA, S.T. Um Estudo do Preconceito na Perspectiva das Representações Sociais: Análise da Influência de um Discurso Justificador da Discriminação no Preconceito Racial. Psicologia: Reflexão e Crítica, 2003, 16(1), pp. 95-107

PetruCCElli, J. L. Mapa da Cor no Ensino Superior Brasileiro. Série Ensaios \& Pesquisas 1. Laboratorio de Políticas Públicas. Programa Políticas da Cor na Educação Brasileira, Governo Federal, 2004. 
PIRES, M. F. de C. O materialismo histórico-dialético e a educação. Interface - Comunicação, Saúde, Educação, Botucatu, v.1, n.1, p. 83-92, ago. 1997.

POTIGUARA, E. Participação dos povos indígenas na Conferência em Durban. Revista Estudos Feministas, 10(1), 2002. Retirado em 28 jun. 2006, de http://www.scielo.br/scielo.php?script= sci_arttext\&pid=S0104026X200200010001 6

RECCO, C. B.; CATARIN, C. R.; BANDOUK, G. L. A Ku Klux Klan e a segregação racial nos Estados Unidos. Historianet: A Nossa História. Retirado em 13/01/2008, no World Wide Web: http://www.historianet.com.br/equipe/

RIBEIRO, C.A.C. Classe, Raça e Mobilidade Social no Brasil. Revista Dados, 49, (4), 2006.

RIO DE JANEIRO. Assembléia Legislativa do Estado do Rio de Janeiro (ALERJ). Lei no 3708, de 09 de novembro de 2001. Retirado em: 12/03/2005, no World Wide Web: http://alerjln1.alerj.rj.gov.br

. Lei $\mathrm{n}^{\circ}$ 3524, de 29 de dezembro de 2000. Retirado em: 12/03/2005, no World Wide Web: http://www.alerj.rj.gov.br/processo2.htm

SAMPAIO, H. A desigualdade no acesso ao Ensino Superior: Observações preliminares sobre os afrodescendentes. Equipe do Núcleo de Pesquisas sobre Ensino Superior (NUPES), Universidade de São Paulo. São Paulo, 2002.

SANÉ, P. Reivindicações Articuladas (e Contestadas) de Reparação dos Crimes da História, a Propósito aa Escravidão e do Colonialismo. Seminário científico da Conferência de Durban. "Reparações e crimes da história: o direito em todas as suas formas", Genebra, 22-23 de março de 2002. Disponível em 20/11/2007, no World Wide Web: http://www.unesco.org.br/publicacoes/copy_of_pdf/Ser iedebates 2.pdf

SANTOS, B. S. Pelas Mãos de Alice: O Social e o Político na Pós Modernidade. 10a ed. São Paulo, Cortez Editora, 2005

SENNETT, R. Autoridade. Rio de Janeiro, RJ, Record, 2001.

SPINI, D.; DOISE, W. Organizing principles of involvement in human right and their social anchoring in values priorities. European Journal of Social Psychology. 28, 603-622

SPINK, M. J. P (Org.). O conhecimento no cotidiano. São Paulo: Brasiliense, 1995. 
STREY, M. N. (Org). Psicologia Social Contemporânea: Livro-texto. Petrópolis, Vozes, 1998

SWANSON, J. L.; FOUAD, N. A. Career Theory \& Practice: Learning Through Case Studies. Sage Publications, Londres, 1999

UNIVERSIDADE FEDERAL DA BAHIA (UFBA). Políticas de Inclusão Social na UFBA: Programa de ações afirmativas, junho de 2004. Retirado em: 12/01/2005, no World Wide Web: http://www.prograd.ufba.br/docs/programa-acoes_afirmativas.doc

UNIVERSIDADE DO ESTADO DO RIO DE JANEIRO (UERJ). Reservas de vagas. Retirado em: 12/01/2005, no World Wide Web: http://www2.uerj.br/ comuns/reserva.htm

VIEIRA, D.; COIMBRA, J.L. A Auto-eficácia na Transição para o Trabalho. IN: Auto-Eficácia em Diferentes Contextos. AZZI, R.G; POLYDORO, S.A.J. (org). Campinas, SP: Ed. Alínea, 2006.

WHITAKER, D.C.A. Escolha da Carreira e Globalização. 11 $1^{\text {a }}$ edição, São Paulo: Moderna, 1997

. UNESP - diferentes perfis de candidatos para diferentes cursos: estudo de variáveis de capital cultural. Série Pesquisas VUNESP, (2), São Paulo: Fundação VUNESP, 1989

WHITAKER, D. C. A. \& FIAMENGUE. Dez anos depois: Diferentes perfis de candidatos para diferentes cursos - estudo da variável capital cultural. Série Pesquisas VUNESP, n.11. São Paulo: Fundação Vunesp, 1999

. A Heterogeneidade Sócio-Econômica dos Vestibulandos dos Diferentes Cursos da UNESP a partir de algumas Variáveis de Capital Cultural. Série Pesquisas VUNESP, n.17, São Paulo: Fundação Vunesp, 2003.

WHITAKER, D. C. A.; ONOFRE, S. A. Representações Sociais em Formação sobre os Vestibulares dos Estudantes de um Cursinho Comunitário na Zona Rural. Revista Brasileira de Orientação Profissional. Ribeirão Preto, SP: Vetor Editora, 7, (1), 2006 
7. Anexos 


\subsection{Anexo A - Modelo de Carta de Autorização para as Instituições}

\begin{tabular}{l} 
Universidade de São Paulo \\
$\begin{array}{c}\text { Faculdade de Filosofia, Ciências e Letras de Ribeirão Preto } \\
\text { Departamento de Psicologia e Educação } \\
\text { Centro de Psicologia Aplicada }\end{array}$ \\
\hline
\end{tabular}

Ribeirão Preto, de 2006 .

Ilmo(a) $\operatorname{Sr}(\mathrm{a})$

Cargo:

Somos do Programa de Pós-Graduação da Faculdade de Filosofia, Ciências e Letras de Ribeirão Preto (USP-SP) e gostaríamos de solicitar autorização para contatarmos entre 10 (dez) e 15 alunos do curso pré-vestibular desta Escola/Instituição, a fim de que possam participar da pesquisa: “Cotas Universitárias: a Visão dos Estudantes em Situação de Vestibular" sob responsabilidade da pesquisadora Fernanda Vieira Guarnieri e orientação da Prof ${ }^{\mathrm{a}} \operatorname{Dr}^{\mathrm{a}}$. Lucy Leal Melo-Silva.

O objetivo do estudo consiste em investigar as opiniões de estudantes em situação de vestibular - de cursinho popular e particular - sobre a implantação do sistema de cotas para ingresso na carreira universitária. Trata-se de uma pesquisa totalmente gratuita. Conta com a participação voluntária dos estudantes e não oferece riscos à saúde do participante e nenhum problema para a Escola/Instituição. Salienta-se que não será realizado qualquer procedimento que não esteja relacionado com a pesquisa. Em relação aos estudantes com idade inferior a 18 anos será solicitada autorização dos pais ou responsáveis.

Para a realização da coleta de dados, as atividades serão divididas em 2 etapas, a saber: (1) aplicação de um questionário - que poderá ser coletivamente em local e horário estabelecido pela instituição, que não interfira nas aulas - e (2) entrevista individual (gravada) com alguns dos participantes selecionados a partir da etapa anterior, que poderá ser na instituição ou na FFCLRP/USP. Os dados coletados serão utilizados para fins acadêmico-científicos e tratados de maneira sigilosa, sem que haja exposição dos participantes. Em caso de interesse por parte da Escola/Instituição, os resultados da pesquisa poderão ser apresentados (após a defesa da dissertação).

Para maiores esclarecimentos, favor entrar em contato. Antecipadamente agradecemos a atenção dispensada.

Prof $^{\text {a }}$ Dr $^{\mathrm{a}}$. Lucy Leal Melo-Silva

(Docente da FFCLRP/USP)
Fernanda Vieira Guarnieri

(Pesquisadora Responsável)

- Fernanda Vieira Guarnieri - Pesquisadora do Programa de Pós-Graduação em Psicologia, da Faculdade de Filosofia, Ciências e Letras (FFCLRP-USP). E-mail: fevigua@yahoo.com.br

- Profa. Dra. Lucy Leal Melo-Silva - Docente do Departamento de Psicologia e Educação da FFCLRP-USP. E-mail: lucileal@ffclrp.usp.br

- Contatos com as pesquisadoras: 3602-3641 / 3602-3739 / 3602-3789 


\subsection{Anexo B - Modelo de Termo de Consentimento Livre e Esclarecido}

$\mathrm{Eu}$,

matriculado(a)

na

Colégio

Curso

Pré-

Vestibular.

concordo

em participar, como voluntário(a), da pesquisa "Cotas universitárias: a visão dos estudantes em situação de vestibular", desenvolvida por Fernanda Vieira Guarnieri, sob supervisão da Prof ${ }^{a}$. Dr ${ }^{a}$. Lucy Leal Melo-Silva, no âmbito do Programa de Pós-Gradação em Psicologia da Faculdade de Filosofia, Ciências e Letras de Ribeirão Preto (FFCLRP/USP).

O objetivo deste estudo consiste em investigar as opiniões de estudantes em situação de vestibular - de cursinho particular e público/popular/comunitário - sobre a implantação do sistema de cotas para ingresso na carreira universitária. Trata-se de uma pesquisa totalmente gratuita. A participação dos estudantes será voluntária e não oferecerá riscos à saúde dos participantes. Salientase que não será realizado qualquer procedimento que não esteja relacionado com a pesquisa.

Para a realização da coleta de dados, as atividades serão divididas em 2 etapas, a saber: (1) aplicação de um questionário e (2) entrevista individual (gravada) com alguns dos participantes selecionados a partir da etapa anterior. Os questionários serão distribuídos na Instituição de ensino dos participantes e poderão ser aplicados coletivamente - em local e horário estabelecidos pela instituição, de modo a não interferir nas aulas - ou levados para serem respondidos em casa. A entrevista poderá ser realizada tanto na própria Instituição de Ensino/Cursinho quanto nas dependências FFCLRP/USP, ou em local definido pela dupla entrevistador-entrevistado.

Há que se acrescentar que os dados coletados serão utilizados para fins acadêmico-científicos e que serão tratados de maneira sigilosa, sem que haja exposição dos participantes.

Declaro, portanto, estar informado sobre as condições para minha participação na presente pesquisa, tendo compreendido com clareza os procedimentos aos quais serei submetido(a), estando ciente de que:

(a) precisarei da assinatura de um responsável para participar da pesquisa caso minha idade seja inferior a 18 anos;

(b) a minha participação consistirá em responder a um questionário, com a maior imparcialidade possível, e, posteriormente, se sorteado, participar de uma entrevista individual (gravada);

(c) não sofri nenhuma forma de pressão, sendo-me permitido deixar de participar do estudo a qualquer momento; e 
(d) se julgar necessário, poderei contar com a assistência da pesquisadora responsável, a partir de agendamento prévio, para possíveis esclarecimentos sobre o tema e caso haja necessidade de suporte emocional decorrentes de questões mobilizadas pelo estudo.

Ribeirão Preto, de 2006.

Assinatura do participante

Nome por extenso
Assinatura do familiar ou responsável

Nome por extenso: ( ) mãe,

( ) pai,

( ) responsável

- Fernanda Vieira Guarnieri - Pesquisadora do Programa de Pós-Graduação em Psicologia, da Faculdade de Filosofia, Ciências e Letras (FFCLRP-USP). E-mail: fevigua@yahoo.com.br

- Profa. Dra. Lucy Leal Melo-Silva - Docente do Departamento de Psicologia e Educação da FFCLRP-USP. E-mail: lucileal@ffclrp.usp.br

- Contatos com as pesquisadoras: 3602-3789 / 3602-3739 


\section{Apêndices}




\subsection{Apêndice A - Modelo do Questionário de Moehlecke (2004)}

QUESTIONÁRIO (para uso do entrevistador)

\begin{tabular}{|l|}
\hline Entrevistador: \\
\hline Data: / / / \\
\hline Número questionário: \\
\hline \hline
\end{tabular}

I. Dados Pessoais

1. Sexo: $\left[\begin{array}{llll} & F & {[}\end{array}\right.$ 2. Estado Civil: 3. Data de nascimento:

4. Local de nascimento: (cidade) (estado)

5. Como você se classificaria de acordo com sua cor/raça?

6. E de acordo com os termos do IBGE, como você se classificaria?

a.[ ] branco b.[ ] pardo c.[ ] preto d.[ ] amarelo e.[ ] indígena

\begin{tabular}{|l|l|l|l|l|l|l|l|l|l|}
\hline \multirow{2}{*}{$\begin{array}{l}\text { Assinale o grau de escolaridade } \\
\text { mais alto: }\end{array}$} & $\begin{array}{l}\text { Ensino } \\
\text { fundamental }\end{array}$ & \multicolumn{2}{l|}{ Ensino Médio } & \multicolumn{2}{l|}{ Curso Superior } & \multicolumn{2}{l|}{ Pós-graduação } \\
\cline { 2 - 9 } & incompleto & completo & incompleto & completo & incompleto & completo & incompleto & completo \\
\hline 7. Grau de escolaridade do pai & & & & & & & & \\
\hline 8. Grau de escolaridade da mãe & & & & & & & & \\
\hline
\end{tabular}

II. Condições sócio-econômicas

9. Gostaria que você me respondesse a quantidade que você possui no seu domicílio dos seguintes itens: (marque um $\mathrm{X}$ na quantidade)

\begin{tabular}{|c|c|c|c|c|c|}
\hline \multirow[t]{2}{*}{ ITENS } & \multicolumn{5}{|c|}{ QUANTIDADE } \\
\hline & Nenhum & 1 & 2 & 3 & 4 ou mais \\
\hline \multicolumn{6}{|l|}{ Carro/automóvel } \\
\hline \multicolumn{6}{|l|}{ TV em cores } \\
\hline \multicolumn{6}{|l|}{ Banheiro } \\
\hline \multicolumn{6}{|l|}{ Empregada mensalista } \\
\hline \multicolumn{6}{|l|}{ Rádio } \\
\hline \multicolumn{6}{|l|}{ Aspirador de pó } \\
\hline \multicolumn{6}{|l|}{ Geladeira duplex ou freezer } \\
\hline \multicolumn{6}{|l|}{ Vídeo cassete } \\
\hline \multicolumn{6}{|l|}{ Máquina de lavar roupa } \\
\hline \multicolumn{6}{|l|}{ 10. Você tem em casa: } \\
\hline \multicolumn{2}{|l|}{ A. ITENS } & \multicolumn{2}{|c|}{ Sim } & \multicolumn{2}{|c|}{ Não } \\
\hline \multicolumn{6}{|l|}{ Telefone celular } \\
\hline \multicolumn{6}{|l|}{ Telefone em casa } \\
\hline \multicolumn{6}{|l|}{ Fax em casa } \\
\hline \multicolumn{6}{|l|}{ Microcomputador em casa } \\
\hline \multicolumn{6}{|l|}{ Acesso a Internet em casa } \\
\hline \multicolumn{6}{|l|}{ TV a cabo/satélite em casa } \\
\hline \multicolumn{6}{|c|}{$\begin{array}{l}\text { 11. Considerando todas as pessoas de sua casa/família que trabalham ou têm algum tipo de rendimento, de } \\
\text { quanto foi a renda total no último mês? }\end{array}$} \\
\hline
\end{tabular}




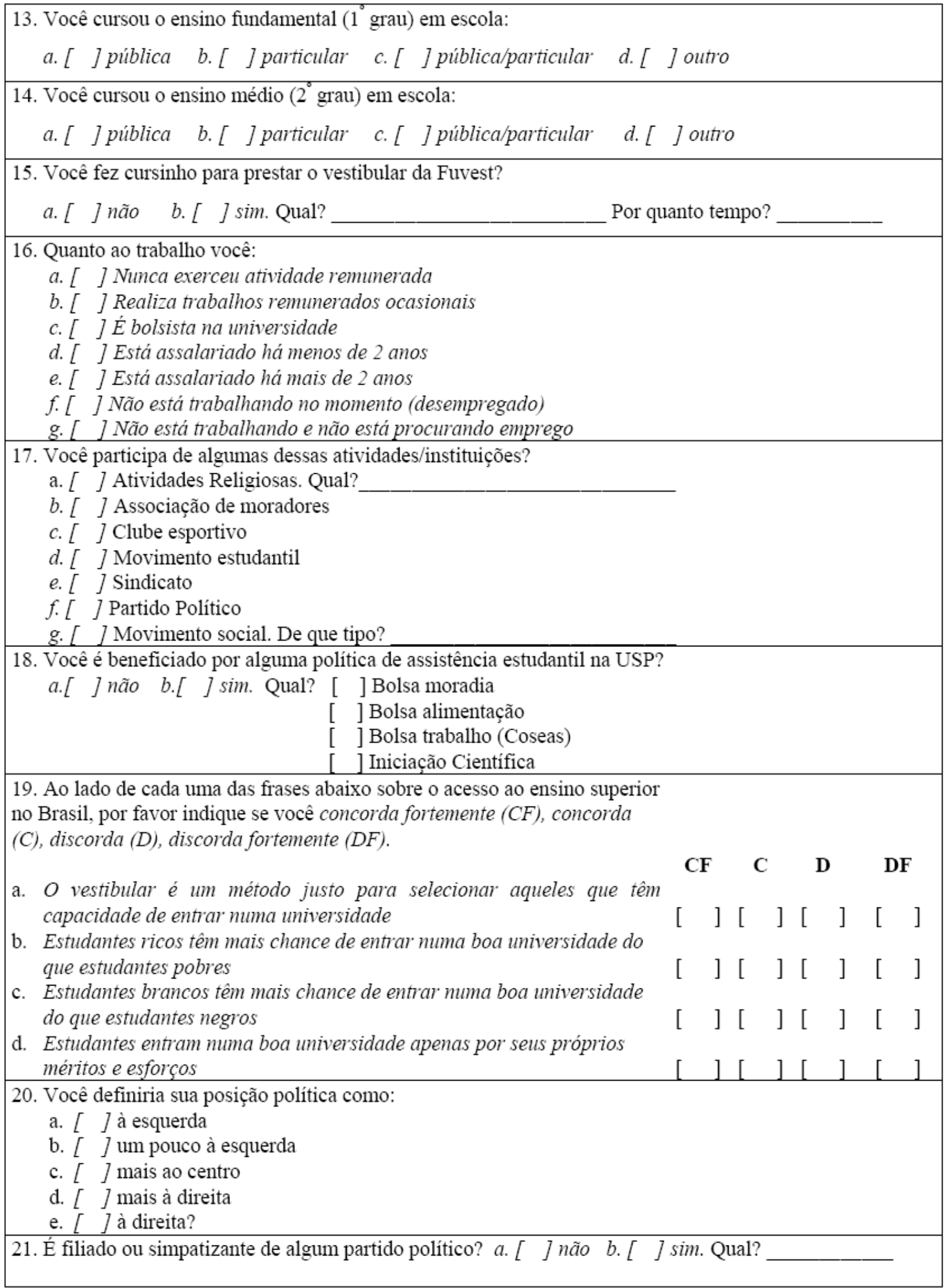


22. Abaixo estão algumas coisas que as pessoas costumam dizer e gostaria que você me dissesse se você concorda fortemente $(C F)$, concorda $(C)$, discorda $(D)$, discorda fortemente (DF).

a. Todas as pessoas, independente de sua cor/raça, deveriam ser tratadas da mesma forma e ter os mesmos direitos

b. Igualdade de oportunidades para brancos e negros é algo importante mas não é realmente uma função do governo garanti-la

c. O governo federal deve fazer de tudo que puder para melhorar as condições sociais e econômicas dos negros

d. O governo não deve fazer nenhum esforço especial para ajudar os negros porque eles mesmos devem se ajudar

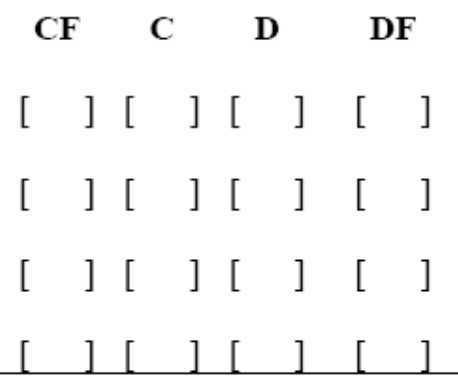

23. De acordo com dados estatísticos, os negros recebem um salário menor que os brancos e são $68 \%$ daqueles que vivem abaixo da linha de pobreza no Brasil. Na sua opinião, qual o principal motivo que leva a população negra a viver em piores condições que a população branca? (Assinale apenas uma resposta)

a. [ ] O preconceito e a discriminação que existe contra os negros

b. [ ]Os negros que não aproveitam as oportunidades que têm para melhorar de vida

c. [ ] A falta de mão-de-obra qualificada negra

d. [ ] Falta de políticas por parte do governo

e. [ ]Outra resposta:

f. [ ] Não sabe

24. Ao lado de cada uma das frases abaixo, por favor indique se você concorda fortemente (CF), concorda (C), discorda (D), discorda fortemente (DF).

a. Se pudessem comer bem e estudar numa boa escola, os negros sempre teriam sucesso profissional

b. Toda raça tem gente competente e incompetente, isso não depende da cor da pele

c. Japoneses, alemães, italianos e outros imigrantes superaram as dificuldades e progrediram socialmente no Brasil. Os negros deveriam fazer o mesmo sem precisar de nenhum favor por parte do Estado ou da sociedade

d. Empenho e esforço na vida oferecem pouca garantia de sucesso para os negros

e. Anos de escravidão e discriminação criaram condições que tornam difíceis para os negros conseguirem sair da pobreza

f. Os negros não têm problemas relacionados à sua cor

g. Os problemas dos negros são iguais àqueles enfrentados pela maioria da população pobre

h. No Brasil, brancos e negros são tratados de forma diferenciada

i. Não existe preconceito no Brasil, pois somos uma nação miscigenada e sem conflitos raciais

25. O que acontecerá se uma pessoa, vinda da escola pública, estudar bastante para o vestibular da Fuvest? Assinale a frase com a qual você mais concorda.
a. [ ] Provavelmente ela conseguirá ingressar no curso desejado se realmente se esforçar, ainda que não seja fácil
b. [ ] Não importa o esforço que ela faça, dificilmente ela terá chances de ingressar
c. [ ] Talvez ela até consiga ingressar, mas apenas nos cursos onde a concorrência é baixa
d. [ ] Depende da capacidade da pessoa
e. [ ] Não sabe 
26. O Ministro da Justiça assinou uma portaria que determina a contratação, até o final de 2002 , de $20 \%$ de negros, $20 \%$ de mulheres e $5 \%$ de portadores de deficiências físicas nos cargos de assessoria do Ministério. Com relação a essa decisão você:
a. [ ] Concorda totalmente
b. [ ] Concorda em parte
c. [ ] Discorda totalmente
d. [ ] Discorda em parte
e. [ ] Não sabe

27. Na USP, apenas $1 \%$ de pretos e $6 \%$ de pardos ingressaram no ano de 2001 , quando eles representam ao todo $25 \%$ da população do Estado. Em 37 cursos, não entrou nenhum estudante que se classificou como preto. Na sua opinião, essa pequena presença de negros na USP ocorre porque: (assinale a frase com a qual você mais concorda)

a. [ ] Como negros são geralmente mais pobres e freqüentaram a escola pública, eles estão menos preparados para o vestibular.

b.[ ] Como os negros sofreram mais discriminação devido à sua cor/raça, tanto na escola quanto na sociedade, eles têm mais dificuldades para entrar numa universidade como a USP

c. [ ] Os negros não estudaram e não se esforçaram o bastante

d. [ ] Devido a maior aptidão dos negros para atividades culturais e esportivas

e. [ ] Porque os negros têm de ir trabalhar desde cedo

f. [ ] Não sabe

28. Você sabia que, já no vestibular de 2003, a UERJ - Universidade Estadual do Rio de Janeiro, vai utilizar cotas para negros e estudantes vindos de escolas públicas?

a. [ ] sabia b. [ ] não sabia

29. O que você acha dessa proposta?
a. [ ] Concorda totalmente
b. [ ] Concorda em parte
c. [ ] Discorda totalmente
d. [ ] Discorda em parte
e. [ ] Não sabe

30. Seria melhor se fossem cotas só para negros?

a. [ ] sim b. [ ] não c.[ ] Não sabe

31. Seria melhor se fossem cotas só para alunos das escolas públicas?

a. [ ] sim b. [ ] não c. [ ] Não sabe

32. Ao lado de cada uma das frases abaixo que as pessoas costumam falar sobre essas políticas, por favor indique se você concorda fortemente $(C F)$,

concorda $(C)$, discorda $(D)$, discorda fortemente $(D F)$.

a. Políticas de cotas são uma boa forma de corrigir desigualdades raciais históricas

b. Políticas de cotas deveriam ser adotadas junto com um maior investimento na educação básica

c. Melhor seria investir apenas na educação básica

d. As pessoas deveriam entrar na universidade somente por seus méritos e esforço próprios

e. A universidade, além do vestibular, deveria também levar em conta na seleção as dificuldades enfrentadas pelos candidatos devido às suas condições sociais e raciais

f. As pessoas não deveriam entrar numa universidade favorecidos por uma lei como a reserva de vagas

g. O vestibular realiza uma seleção injusta e deveria ser modificado

h. O vestibular é injusto e deveria ser extinto

\begin{tabular}{|c|c|c|c|c|}
\hline CF & C & & & DF \\
\hline$\left[\begin{array}{ll}{[} & ]\end{array}\right.$ & {$\left[\begin{array}{ll} & ]\end{array}\right]$} & [ & ] & {$\left[\begin{array}{ll}{[} & ]\end{array}\right.$} \\
\hline J & {$\left[\begin{array}{ll}{[} & ]\end{array}\right.$} & [ & 1 & [ \\
\hline J & {$\left[\begin{array}{ll}{[} & ]\end{array}\right.$} & [ & ] & {$\left[\begin{array}{ll}{[} & ]\end{array}\right.$} \\
\hline ] & {$\left[\begin{array}{ll} & ]\end{array}\right]$} & [ & ] & {$\left[\begin{array}{ll}{[} & ]\end{array}\right.$} \\
\hline$\left[\begin{array}{ll}{[} & ]\end{array}\right]$ & {$\left[\begin{array}{ll} & ]\end{array}\right]$} & & ] & {$\left[\begin{array}{ll}{[} & ]\end{array}\right.$} \\
\hline ] & ] & & & \\
\hline$]$ & & & & \\
\hline
\end{tabular}




\subsection{Apêndice B - Etapas da Elaboração do Questionário COTAS}

A base da elaboração do questionário COTAS contou com um instrumento já utilizado anteriormente por Moehlecke (2004). Tal instrumento foi selecionado por ser um instrumento útil para abordar o objeto de investigação deste estudo e por permitir o levantamento de informações sobre os participantes, fornecendo dados do perfil dos grupos estudados. A etapa inicial de elaboração contou com uma etapa piloto, na qual o questionário foi aplicado em 15 estudantes de cursinhos particulares e 17 de cursos alternativos. Após ter passado por adaptações para aproximá-lo dos objetivos do presente, o questionário foi intitulado "Mapeamento da Opinião sobre Cotas Universitárias" ou COTAS, como mostra o Anexo A.

O questionário original (MOEHLECKE, 2004) é composto por questões que vão de 1 a 32, organizadas em: (1) variáveis respostas, e (2) variáveis explicativas a serem avaliadas. O primeiro caso engloba as questões 26, 28, 29, 30, 31, 32a, 32b, 32c e 32e. Já as variáveis explicativas a serem avaliadas somam oito, a saber: (a) pertencimento racial, nas questões 5 e 6; (b) condição socioeconômica, questões 7, 8, 9 e 10; (c) pertencer ou não à universidade USP, (d) posições políticas, nas questões 20 e 21; (e) posições em relação a noções de igualdade nas questões 24b, 24c, 22a e 22c; (f) posições sobre as relações raciais nas questões 19c, 23, 24a, 24e, 24f, 24g, 24h e 27; (g) posições sobre o valor do mérito, em 19d, 24d e 25; e por fim (h) posições sobre o vestibular em 19a, 32h e 32h. Já o questionário atual (COTAS), apresenta algumas alterações em relação ao original. Algumas das questões que foram excluídas e ou alteradas (Tabela 3). As questões mantidas foram: As questões eliminadas foram: 10, 11, 15, 16, 17, 18. 20, 21, 26 e 27.

Tabela 3 - Estrutura do questionário COTAS com relação ao original (MOEHLECKE, 2004)

\begin{tabular}{|c|c|c|c|c|}
\hline $\begin{array}{c}\text { Questionário } \\
\text { COTAS }\end{array}$ & Mantidas & Alteradas & Acrescentadas & Equivalência com o original \\
\hline 1 & & $\mathrm{X}$ & & \multirow{3}{*}{$13^{*}$ e $14^{*}$} \\
\hline 2 & & $\mathrm{X}$ & & \\
\hline 3 & & $\mathrm{X}$ & & \\
\hline 4 & & & $\mathrm{X}$ & - \\
\hline 5 & & & $\mathrm{X}$ & - \\
\hline 6 & & $\mathrm{X}$ & & $7^{*}$ e $8^{*}$ \\
\hline 7 & & & $\mathrm{X}$ & - \\
\hline 8 & ANULADA & ANULADA & ANULADA & ANULADA \\
\hline 9 & $\mathrm{X}$ & & & 12 \\
\hline 10 & $\mathrm{X}$ & & & 5 \\
\hline 11 & $\mathrm{X}$ & & & 6 \\
\hline 12 & $\mathrm{X}$ & & & 19 \\
\hline 13 & $\mathrm{X}$ & & & 22 \\
\hline 14 & $\mathrm{X}$ & & & 23 \\
\hline 15 & $\mathrm{X}$ & & & 24 \\
\hline 16 & $\mathrm{X}$ & & & 25 \\
\hline
\end{tabular}




\begin{tabular}{|c|c|c|c|c|}
\hline 17 & & & $\mathrm{X}$ & - \\
\hline 17.1 & & & $\mathrm{X}$ & - \\
\hline 17.2 & & $\mathrm{X}$ & & $30^{*} \mathrm{e} 31^{*}$ \\
\hline 18 & $\mathrm{X}$ & & & 32 \\
\hline 19 & & & $\mathrm{X}$ & - \\
\hline 20 & & & $\mathrm{X}$ & - \\
\hline 20.1 & & & $\mathrm{X}$ & - \\
\hline 21 & & $\mathrm{X}$ & & $1,3^{*} \mathrm{e} 4^{*}$ \\
\hline
\end{tabular}

(*) Com alterações na redação ou na atualização do conteúdo

A questão 8 foi anulada pelo fato de não representar um indicio significativo ao ser avaliada individualmente, visto que as questões 9,10 e 11 do original a complementavam foram retiradas do COTAS. Tais questões, referentes ao Critério Brasil, não foram utilizadas visto que para o presente estudo os critérios socioeconômicos foram investigados com base em variáveis de capital cultural dos participantes - como a escolarização e ocupação profissional dos pais - o que justifica a inserção da questão 7 (profissão, ocupação atual, se exerce ou não atividade remunerada) do COTAS, associada à questão 6 (escolarização dos pais por nível e natureza administrativa). As questões 15, 16 e 18 foram excluídas por abordar especificamente a Universidade de São Paulo, relevante para aquele estudo, porém não se relaciona aos objetivos deste estudo. Os conteúdos das questões 17, 20 e 21, também, não foram considerados relevantes neste estudo por se tratar de informações sobre afiliação partidária política dos participantes. As questões 26 e 27 foram excluídas por se tratar de dados já desatualizados comparativamente ao ano de 2006, evitando-se, portanto, equívocos desnecessários à elaboração do questionário.

Acrescentou-se, por fim, uma questão aberta para comentários dos participantes sobre o questionário e/ou sobre a temática levantada. Foram sugeridas algumas alterações na sessão de comentários, muitas das quais acatadas por melhorarem a clareza do material. Sucedeu ao estudo piloto a avaliação do instrumento pelos membros do grupo de estudos do Centro de Psicodiagnóstico em Psicologia (CPP), sediado na Faculdade de Filosofia, Ciências e Letras de Ribeirão Preto e do qual a pesquisadora e a orientadora fazem parte. Outras alterações foram sugeridas, trazendo contribuições em termos de adequação do questionário aos objetivos da presente pesquisa. 